\title{
Almanya, İsviçre ve Avusturya Hukuku Bağlamında Türk Ceza Muhakemesi Hukukunda Adlî DNA Analizleri
}

\author{
Forensic DNA Analysis in the Turkish Criminal Procedure Law in the \\ Context of the Law of Germany, Switzerland and Austria
}

\section{Gülsün Ayhan AYGÖRMEZ UĞURLUBAY ${ }^{1}$}

${ }^{1}$ Doç. Dr., Bielefeld Üniversitesi, Hukuk Fakültesi, Bielefeld, Almanya

\section{ÖZ}

Keşfi ile ceza muhakemesi hukukunda devrim yaratan ve bir dönem üzerinde hararetli tartışmaların yapıldığı moleküler genetik incelemelere ilişkin hukukî tartışmalar günümüzde artık arka planda kalmış olsa da ceza muhakemesi hukukunda adlî DNA incelemelerine ilişkin gelişmeler aslında ne tam olarak sonlandırılmış ne de bu husustaki sorunlara tam olarak çözüm bulunabilmiştir. Mevcut çalışma, Türk ceza muhakemesi hukukunda moleküler genetik incelemeleri yeniden mercek altına alarak, DNA profillerinin TürkCMK kapsamında kaydedilmesi ile Türkiye Milli DNA Bankasının kurulması gibi hususları yeniden tartışmaya açma hedefindedir.

Çalışma üç ana bölümden oluşmaktadır. Illk bölümde ceza muhakemesinde DNA analizlerine genel giriş yapılmış ve DNA analizlerinin ceza muhakemesi alanındaki tarihsel gelişimlerine kısaca değinilmiş, bunun ardından DNA analizlerinin temel haklar karşıındaki durumu ele alınmıştır. Çalışmanın ikinci bölümünde DNA analizlerine ilişkin Almanya, Avusturya, İsviçre ve Türkiye mevzuatı aktarılmış, bu esnada Alman ve Türk hukukuna ağırlık verilmiştir. Çalışmanın son aşamasında anılan ülkelerde bulunan ancak Türk ceza muhakemesi hukukunda yer almayan iki hükmün (gelecek yargılamalarda kullanılmak üzere DNA anali-zi yapılması ve DNA profillerinin kaydedilmesi ile kitlesel DNA analizleri) de lege ferenda Türk ceza muhakemesi hukukunda öngörülmesi ve bunlarla bağlantılı Türkiye Milli DNA Bankası kurulması önerileri gerekçeleriyle birlikte ortaya konulmuştur.

Anahtar Kelimeler: Moleküler genetik araştırma, adlî DNA analizi, DNA profili, kitle DNA analizleri, DNA veri bankası

\section{ABSTRACT}

Developments of the judicial DNA examinations in criminal procedure law have never been completely terminated or fully resolved. Even the legal debates that revolutionized criminal law have now receded into the background. The present study is aimed at rediscussing such issues as creating the authority to record DNA profiles under the criminal procedure law and establishing the national DNA bank of Turkey by reexamining molecular genetic studies in Turkish criminal procedure law.

This study consists of three main parts. The first part includes a general introduction to DNA analysis in criminal proceedings, a short history of DNA analyzes in criminal procedure law and an explanation of the status of DNA analyzes against fundamental rights. In the second part of the work, the legislation on DNA analysis of Germany, Austria, Switzerland and Turkey is reviewed with an emphasis given to German and Turkish law. The last part of study deals with the need to foresee two new norms in Turkish Criminal Procedure Law on generating DNA analyzes, recording DNA profiles and analyzing mass DNA data for the future criminal proceedings.

Keywords: Research of Molecular Genetics, Forensic DNA Analysis, DNA Profile, Mass DNA Analysis, DNA Data Bank

Date of receipt: $23.12 .2016 \cdot$ Date of acceptance: 26.12 .2016

Corresponding author: Gülsün Ayhan Aygörmez Uğurlubay, E-mail: guelsuen_ayhan.aygoermez@uni-bielefeld.de

Citation: Aygörmez Uğurlubay, G. A. (2017). Almanya, İsviçre ve Avusturya hukuku bağlamında Türk Ceza Muhakemesi hukukunda adlî DNA analizleri. Ceza Hukuku ve Kriminoloji Dergisi-Journal of Penal Law and Criminology 2017; 5(2):29-87.

https://doi.org/10.26650/JPLC360265 


\section{EXTENDED ABSTRACT}

Developments about the judicial DNA examinations in criminal procedure law have neither been completely terminated nor fully resolved. Even the legal debates, which revolutionized criminal law, have now subsided into the background. The present study is aimed at re-discussing such issues as creating the authority to record DNA profiles under the criminal procedure law and establishing the national DNA bank of Turkey by re-examining molecular genetic studies in Turkish criminal procedure law.

Indeed, first of all there is no consensus on the concept of judicial DNA examinations and the implications of these examinations on constitutional rights. In particular, the immunity of human dignity, the context of protection of body integrity, fundamental human rights, and the right to determine the future of personal information (autonomy of information or autonomy of informing) i.e., the right to request the protection of personal data, will be appropriate topics of the discussion in studies of judicial DNA within Turkish and comparative law. Although the private aspects of human life will not be invaded via judicial DNA examinations, obtaining personal DNA profiles is an attack on the private lives of people and it may not be required that everyone knows the direct or indirect information to be obtained as a result of the examination. Furthermore, the generation, using, processing, recording, detection, etc. of DNA profiles are attacks on the right to autonomy of informing which is in under the protection of the constitution. DNA profiles are personal data, and because of that, DNA profiles are under protection of Turkish Constitution Article 20/III. With a change in criminal procedure law, provisions that can be created about the making, recording and re-using judicial DNA analysis to be used in future jurisdiction may mean violating people's rights to privacy and autonomy of information. For this reason, restrictions of these rights should be in accordance with the constitution.

Beside the described matters, there is no provision about the processing and recording of DNA profiles in future jurisdiction and conducting mass DNA analyzes in Turkish Criminal Law. Unlike Turkish Criminal Procedure Law, there are four provisions in German Criminal Law. German Criminal Law Article 81/a is related to a suspect/defendant's physical examination, German Procedure Criminal Law Article $81 / \mathrm{c}$ is related to another's physical examination, German Criminal Procedure Law Article 81/e is related to genetic molecular examination and German 
Criminal Procedure Law Article 81/f is related to procedure of genetic molecular examination. Austrian Criminal Procedure Law Article 124 and Swiss Criminal Procedure Law Article 255 are the equivalent of the Turkish Criminal Procedure Law Art 75 and German Criminal Law Article 81. As said before, in Turkish Criminal Procedure Law there is no provision about the recording of DNA profiles to be used in future jurisdictions. Despite that, detailed regulations have been made in German Criminal Procedure Law Article 81/g, Swiss Criminal Procedure Law Article 256 and Austrian Security Forces Article 67. Similarly, the regulation on mass DNA analyzes are in German Criminal Procedure Law Article 81/h and Swiss Procedure Law Article 257 although they are not included in Turkish Criminal Procedure Law.

A norm like that in German Criminal Procedure Law Article 81/g does not exist in Turkish Criminal Procedure Law. The other norms about DNA analyzes in German Criminal Law are similar to the norms in Turkish Criminal Procedure Law. Other than this, a new norm (Turkish Criminal Procedure Law Article 78/A) should be introduced about generating and recording to be used in future jurisdictions with comparative law, German Criminal Procedure Law Article 81/g, Swiss Criminal Procedure Law Article 256 and Austrian Security Forces Article 67 in mind. The same is valid for mass DNA analyzes too. When considering the comparative law regulations and discussions, the addition of a de lege ferenda norm (Turkish Criminal Procedure Law Article 78/B) to Criminal Procedure Law would be appropriate. This new norm should be reconsidered in the context of DNA data and the Turkish National DNA Database Law Draft and this draft should be passed immediately.

This study consists of three main parts. The first part includes a general introduction to DNA analysis in criminal proceedings and a short history of DNA analyzes on criminal procedure law and includes the status of DNA analyzes against fundamental rights. In the second part of the work, legislation from Germany, Austria, Switzerland and Turkey on DNA analysis was reviewed, and German and Turkish law was emphasized.

The last part of study deals with the need to foresee two new norms in Turkish Criminal Procedure Law on generating DNA analyzes, recording DNA profiles and analyzing mass DNA data for the future criminal proceedings. 


\section{Genel Olarak Moleküler Genetik İncelemeler}

\subsection{Moleküler Genetik İncelemelerin Ceza Muhakemesi Hukukuna Girmesi}

Genetik alanında yapılan önemli gelişmelerle biyoloji bilimi son yıllarda büyük ilerleme kaydederek yüzyılın en önemli bilim dallarından biri hâline gelmiştir. Gerçekten de yüzyılın ilk yarısında Mendel kurallarına göre şekillenen klasik genetik, 1900'lü yılların ortalarına gelindiğinde "biyokimyasal genetik" yoluyla daha da gelişmiş, ${ }^{1} 1944$ yılında Amerikalı bilim adamı Oswald T. Avery'nin çalışmaları sonucu, genlerin maddesel yapılarının "deoksiribonükleik asit - deoxyribonucleic acid [DNA] -Desoxyribonukleinsäure [DNS]) olarak tanımlanması ile² DNA'ların "kalıtımsal bilgilerin taşıyıcısı"’3 olduğu ortaya çıkmıştır. 1953 yılında James Watson ve Francis Crick tarafından DNA'ların çifte sarmallı, yani moleküler boyutta yapılarının keşfi ile de, moleküler genetik devrimi yaşanmıştır. ${ }^{4}$

İngiliz moleküler biyolog Alex J. Jeffreys' in 1985 yılında DNA dizilerinin her insan için farkl1, dolayısıyla her insan için karakteristik olduğunu ortaya koyması ve bunlar1 "genetik parmak izi" olarak nitelendirmesi ile "genetik parmak izi araştırmaları", başka bir ifadeyle "moleküler genetik incelemeler" kriminalistik, adlî tıp ve ceza soruşturmalarında uygulama bularak, önem kazanmaya başlamıştır. Bu bağlamda İngiltere'de büyük yankı uyandıran Pitchfork olayının DNA profilleri aracılığıyla aydınlatılması, suçların aydınlatılmasında DNA parmak izi döneminin başlamasına neden olmuştur. Pitchfork olayında 1983 ve 1986 yıllarında iki kız çocuğu cinsel saldırıya uğradıktan sonra öldürülmüş; arkasından tutuklanan faillin DNA profili, mağdurlar üzerinde bulunan ve aynı kişiye ait olduğu sabit olan DNA profili ile uyuşmayınca, bölgede oturan 13-30 yaş arasındaki 5511 erkeğe DNA örneği verme çağrısında bulunulmuş; ancak çağrı sonucu elde edilen hiçbir DNA profili mevcut fail profili ile uyuşmayınca, araştırma ilk aşamada neticesiz kalmıştır. Ancak kısa bir süre sonra tesadüfen bir barda birkaç kişinin kendi arasında yaptığ 1 bir sohbete kulak misafiri olan birinin, duyduklarını kolluk kuvvetleriyle paylaşmasıyla, olayın seyrini değiştirecek bir gerçek gün yüzüne çıkmıştır. Sohbette, Pitchfork adındaki işçinin toplu DNA analizi çağrısına uymayarak, analiz yaptırmaya kendi

\footnotetext{
DECHEMA, s. 1, 2.

Ellermann/Opolka, s. 14.

Nagl, s. 4, 5; DECHEMA, s. 2, 3.

DECHEMA, s. 1, 2; Ellermann/Opolka, s. 14.

Harbort, s. 155; Benecke, s. 43; Klumpe, s. 48.
} 
yerine başkasını yolladığından söz edilmiştir. Yapılan soruşturmada gerçekten de Pitchfork'un işyerinden bir meslektaşı ile 200 pound karşılığında kendi kimliği ile DNA analizi yaptırma konusunda anlaştığı ortaya çıkmıştır. En nihayetinde Pitchfork'tan alınan biyolojik örnek üzerinde yapılan DNA testi ile elde edilen profil, iki mağdurun üzerinden elde edilen DNA profiliyle eşleşmiştir. Bu vesileyle 1988 yılında Colin Pitchfork, dünyada DNA profili aracılığı ile yargılanıp suçlu bulunan ilk kişi olmuştur. ${ }^{6}$

Ancak Pitchfork olayından bir y1l önce Ekim 1987'de başka bir olayda İngiltere'de Birmingham Crown Mahkemesi ${ }^{7}$; 1988 yılında Amerika'da da New Yorklu hâkim Joseph Harris tarafindan DNA analizi ceza muhakemesi hukukunda hukuka uygun geçerli bir delil olarak kabul edilmiştir. ${ }^{8}$ Alman ceza muhakemesinde de DNA analizlerini hukuken geçerli bir delil olarak kabul eden ilk mahkeme, 1988 yılında Berlin Ağır Ceza Mahkemesi ${ }^{9}$ (Landgericht) olmuştur. Bunu Darmstadt Ağır Ceza Mahkemesi ${ }^{10}$, Heilbronn Ağır Ceza Mahkemesi ${ }^{11}$ olmak üzere çeşitli Alman mahkemeleri izlemiştir. En nihayetinde konu 1990 y1lında Alman Federal Mahkemesi ${ }^{12}$ (Bundesgerichtshof - Yargitay), 1995 yılında da Alman Federal Anayasa Mahkemesi ${ }^{13}$ (Bundesverfassungsgericht) tarafindan ele alınarak, DNA analizlerinin ceza muhakemesi hukukunda geçerli bir delil aracı teşkil ettikleri kabul edilmiştir.

Adlî DNA analizi ile ilgili adlî tıp ve iz bilimi alanındaki gelişmeler yasa koyucunun ve yargı organlarının da dikkatini çekmiş, Almanya'da 1987 sonrası bu hususta çalışmalarda bulunmak ve görüş bildirmek üzere etik kurula başvurulmuş, araştırma grupları oluşturulmuştur. ${ }^{14}$ Tartışmalar neticesinde 1992 yılında DNA analizlerine ilişkin bir Yasa Tasarısı meclise sunulmuştur. ${ }^{15}$ DNA analizleri Alman ceza muhakemesi mevzuatına girişi ise 1997 yılında olmuştur. Gerçekten de 22.3.1997 yılında yürürlüğe giren Ceza Muhakemesi Değişikliği Kanunu - DNA Analizi

\footnotetext{
$6 \quad$ Klumpe, s. 49, 50.

7 Burr, s. 11; Klumpe, s. 50.

8 Burr, s. 10; Hetger, s. 335.

9 LG Berlin NJW 1989, s. 787.

10 LG Darmstadt NJW 1989, s. 2338.

11 LG Heilbonn NJW 1990, s. 784.

12 BGH NJW 1990, s. 2328; BGHSt 37, s. 157.

13 BVerfG NStZ 1996, s. 45; Neuser, s. 60.

14 Ayrintılı Klumpe, s. 117 vd.

15 Klumpe, s. 118.
} 
(genetik parmak izi) ${ }^{16}$ ile (Strafverfahrensänderungsgesetz-DNA-Analyse „,Genetischer Fingerabdruck") getirilen "moleküler genetik incelemeler" başl1klı AlmanCMK m. 81e ile DNA analizi, ilk defa yasal zemine oturtulmuştur. ${ }^{17}$ Getirilen bu hüküm hâlihazırda görülmekte olan ceza yargılamalarına yöneliktir.

DNA analizinin, faillerin kimliklerinin ortaya çıkarılmasında hata oranı düşük bir yöntem olması; cinsel suçlardan, şiddet içeren tüm diğer fillere kadar geniş bir alanda, gerek failden mağdura ya da ortama gerekse mağdurdan ya da ortamdan faile DNA örneği içerebilecek vücut doku ya da sıvıların vs. aktarılma olasılığı; ayrıca önceleri üzerinde hiç bir incelemeyle sonuç alınamayacak izlerden de DNA'lara ulaşılarak, malvarlığına karşı suçların dahi aydınlatılabilmesi imkânı, kriminalistik biliminde DNA analizinin kullanımı alanının ileri derecede genişlemesini sağlamıştır. Zaman içerisinde cezalarının infazı sonrası - başta cinsel suçlar olmak üzere - serbest bırakılanların yeniden suç işlemeleri olgusu karşısında, suçların hızlı bir şekilde aydınlatılması için DNA profillerinin kaydedilmesi gereği gündeme gelmiş; bu da gelecekteki yargılamalarda kullanılmak üzere DNA profili elde etme ve bunları DNA veri bankalarına kaydetme düşüncelerinin doğmasına vesile olmuştur.

Bu bağlamda 17.04.1998 yılında Federal Suçlar Bürosu (Bundeskriminalamt) kapsamında merkezi DNA analizi verileri bankasının kurulması ile 07.09.1998 yılında DNA Kimlik Tespiti Kanunu ${ }^{18}$ (DNA-Identitätsfeststellungsgesetz) Federal Resmî Gazete'de yayımlanmış, Kanun ile sonraki ceza yargılamalarında kimliğin tespiti amacıyla kullanılmak üzere vücuttan örnek alınması ve alınan örneklerden moleküler genetik inceleme yapılması ve DNA kimlik şablonları yani DNA profillerinin Federal Suçlar Bürosundaki Veri Bankasına kaydedilmesi öngörülmüştür. Bunun ardından, Kanun'un birinci maddesine dayanılarak AlmCMK içerisine, gelecekteki suçların aydınlatılmasını sağlamayı hedefleyen, "DNA kimlik tespiti" başlıklı 81g numaralı madde eklenmiştir. ${ }^{19}$ Tüm bu yasal gelişmeleri 12.08.2005

16 Federal Resmi Gazete Kanun metni http://www.bgbl.de/xaver/bgbl/start.xav?start=//*05B@attr $\mathrm{id}=$ 'bgbl197s 0534.pdf'\%5D\# bgbl \%2F\%2F*\%5B\%40attr id\%3D\%27bgbl197s 0534. pdf $\% 27 \% 5 \mathrm{D} \_1480256804001$, son erişim: 10.01 .2017$.

17 Ayrıntılı bilgi için Senge, NJW 1997, s. 2410.

18 Federal Resmi Gazete Kanun metni http://www.bgbl.de/xaver/bgbl/start.xav?startbk=Bundesanzeiger_ BGB1\&start=//*\%255B@attr_id='bgb1198s2646.pdf \%255D\#_bgbl__\%2F\%2F*05B\%40attr_ id\%3D\%27bgbl198s2646.pdf\%27\%5D_1480256987136, son erişim: 10.01 .2017 .

Ayrıntılı Rackow, s. 17-18; Volk, NStZ 2002, s. 561. 
tarihinde çıkarılan "Adlî DNA-Analizleri Hükümlerinin Yenilenmesi Kanunu”20 (das Gesetz zur Novellierung der forensischen DNA-Analyse) izlemiştir. Bu Kanun kapsamında AlmCMK m. $81 \mathrm{~g}$ ve füzerinde bazı değişiklikler yapılmış, AlmCMK'sına kitleseladlîmolekülergenetikincelemeleri(molekulargenetischeReihenuntersuchung) konu alan “DNA-Kitlesel Inceleme - DNA-Reihenuntersuchung” başl1kl1 $81 \mathrm{~h}$ numaralı yeni bir madde eklenmiş ve en nihayetinde DNA Kimlik Tespiti Kanunu içerisindeki hükümler Alman CMK m. 81g IV ve V içerisine aktarılarak, DNA Kimlik Tespiti Kanunu yürürlükten kaldırılmıştır. ${ }^{21}$

Türkiye'de mevcut CMK öncesi yürürlükte olan 1412 sayılı mülga Ceza Muhakemeleri Usulü Kanunu kapsamında ne moleküler genetik incelemelerin yapılmasına ne bu amaçla vücuttan örnek alınabilmesine ilişkin bir hüküm yer almıştır. Ancak her ne kadar tüm bu hususlarda "Hazırlık soruşturmasında muayeneleri icab eden kimselerin muayeneleri Cumhuriyet Savclarının talebi ile yapılır" hükmünü içeren m. 66'ya başvurulabileceği öğretide ${ }^{22}$ dile getirilmiş olsa da, anılan hükmün özellikle moleküler genetik incelemeler yapılabilmesini hukuken caiz kılacak nitelikte olmadığ 1 şeklinde haklı eleştirilere ${ }^{23}$ sebep olmuş; konuya ilişkin de lege ferenda yasal bir düzenleme yapılması gereği ${ }^{24}$ dile getirilmiştir. Ceza muhakemesi hukukunda DNA analizlerine yönelik çeşitli CMK Tasarılarında hükümler yer alsa da (örneğin 2001 Tasarısı'nın 81, 82. maddeleri, 2004 Tasarısı m.

20 Federal Resmi Gazete Kanun metni http://www.bgbl.de/xaver/bgbl/start.xav?startbk=Bundesanzeiger

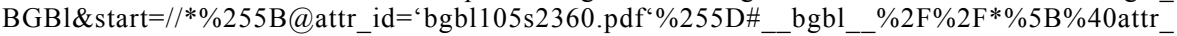
id\%3D\%27bgbl105s2360.pdf\% $27 \% 5 \mathrm{D} \_1480256181030$, son erişim: $11.0 \overline{1.2} 017$.

21 Ayrıntılı açıklamalar için Neuser, s. 256 vd.; Finger, s. 696; Schewe, JR 2006, s. 188; Bergemann/Hornung, StV 2007, s. 165.

22 Özbek, son erişim: 6.1.2017: “Bugün uygulamamızda söz konusu hükme dayanılarak vücut üzerinde inceleme ve muayene hazırlık soruşturmasında savcının emri ile yapılmakta ve polis tarafindan da uygulanmaktadır. Bu çerçevede kişiden kan, saç vb. alınarak tahlil yapılması, kızlık zarı kontrolü, hatta zaman zaman DNA-Analizi, deyim yerindeyse hep bu mütevazı hükme dayanılarak yapılmaktadır."; krş. ayrıca Batur, TBBD 2016 (126), s. 72, 73; beden muayeneleri bakımından Aksoy İpekcioğlu, iç: Centel’e Armağan, s. 1158.

23 Özbek, son erişim: 6.1.2017: "Kişinin genetik kimliğinin deşifre edilmesi sonucuna yol açan ve gen teknolojisinin bugün ulaştı̆̆ı seviye karşısında kötüye kullanma olasılığının arttı̆̆ DNA-Analizi bakımından CMUK m.66/son'un ihtiyaca cevap verebilecek nitelikte olmadığ söylenmelidir. Zira ilgili hükümler analize kime karşı, hangi koşullar altında ve kimin tarafindan başvurulabileceği ve özellikle de elde edilen verilerin akıbeti hususunda yeterli açıklığa sahip değildir. Artık bu konuda CMUK'a ayrı, açık ve ayrıntıl bir hüküm veya hükümler getirmenin zamanı gelmiştir. Bugünkü düzenleme ile vücudun muayenesi tedbiri altında DNA-Analizine başvurulması kanımızca oranlılık ilkesi ve bu ilke ile iç içe olan hukuk devleti ilkesine aykırıdır."; krş. Aksoy İpekcioğlu, iç: Centel'e Armağan, s. 1158, maddede bir cümle ile düzenlenen bu hükmün özellikle şüpheli ve sanık haklarının ihlaline yol açabileceğini, zira bu hükümde doğrudan vücuda müdahale oluşturan işlemin koşullarının ayrıntılı bir şekilde düzenlenmediğini ifade etmektedir; Batur, TBBD 2016 (126), s. 72, 73. 
78, 79) ceza muhakemesi hukukunda DNA analizlerinin yasal zemine kavuşması ilk defa 5271 sayılı Ceza Muhakemesi Kanunu ile mümkün olabilmiştir. 5271 sayılı CMK m. 75'te şüpheli veya sanığa, m. 76' da da diğer kişilere yönelik vücuttan örnek alma; m. 78' de (79 ve 80) ise alınan örnekler üzerinde moleküler genetik incelemelerde bulunma ve bunlara ilişkin usuller öngörülmüştür. Bununla birlikte TürkCMK içerisinde ileriki ceza yargılamalarında kullanılmak üzere DNA profillerinin oluşturulması ve bunların, karşılaştırmak üzere sisteme kaydedilmelerine ilişkin ya da kitlesel DNA analizlerine ilişkin açık bir hükme yer verilmemiştir. Tüm bunların yanında, 2007 tarihinde Adalet Bakanlığı tarafindan hazırlanan "DNA Verileri ve Millı̂ DNA Veri Bankası Kanunu Tasarısı"25, 14 Nisan 2008 tarihinde Başbakanlık tarafından iade edilmiş, aradan geçen 8 yıla rağmen Başbakanlığa ne bu Tasarı ne de yeni başka bir tasarı sunulabilmiştir. Şu hâlde DNA analizleri konusundaki 2000'lerin başında hızlı bir ilerleme kaydedilmiş olsa da kısa bir süre içerisinde bu ilerleme yine hızlı bir şekilde son bulmuştur. İleride de aktarılacağı üzere bu durum suçların aydınlatılmasında Türkiye'yi geride bırakmaktadır.

\subsection{Adlî DNA İncelemeleri Üzerine Kavramsal Tartışmalar}

Ne Türk ne de Alman ceza muhakemesi hukukunda DNA analizi kavramına yönelik tam bir fikir birliği bulunmaktadır.

Mevzuatlarında birbirine benzer düzenlemelerin yer aldığı AlmCMK m. 81e ve 2005 yılında Almanya'da yürürlükten kaldırılan DNA Kimlik Tespiti Kanunu; AvCMK m. 124 ve TürkCMK m. 78 ile Türkiye'deki Ceza Muhakemesinde Beden Muayenesi, Genetik Incelemeler ve Fizik Kimliğin Tespiti Hakkında Yönetmelik ${ }^{26}$ "moleküler genetik inceleme" kavramına; ileriki ceza yargılamalarına kullanılmak üzere DNA profili oluşturmaya yönelik AlmCMK m. 81g “DNA-Kimlik Tespiti”, toplu DNA analizlerini öngören m. $81 \mathrm{~h}$ "DNA-Kitlesel Inceleme" kavramlarına; İsvCMK m. 255 ile İsviçre DNA Profilleri Kanunu ve en nihayetinde Türkiye'de DNA Verileri ve Millî DNA Veri Bankası Kanunu Tasarısı, "DNA analizi” kavramına yer vermiş; Kanun' da ceza yargılaması ile alakalı olan DNA analizleri ise adlî amaçlı DNA analizi olarak nitelendirilmiştir.

Öğretide k1smen "genom analizi - Genomanalyse"27, k1smen "gen analizi -

Tasarı ve gerekçesi için bkz. http://www.ttb.org.tr/index.php/Haberler/dna-verileri-ve-tye-milli-dna-veribankasnunu-tasar-471.html, son erişim: 3.12.2016. 
Genanalyse"28, k1smen "moleküler genetik inceleme/araştırmalar molekulargenetische Untersuchung"29, k1smen de "DNA analizi - DNA-Analyse"30 kavramlarının kullanıldığı; ancak özellikle son iki kavramının birbirinden ayrılmadan, sıklıkla birlikte ya da birbirinin yerine kullanıldı̆̆ı görülmektedir.

Aktarılan bu kavramlardan özellikle genom ve gen analizi kavramları ceza muhakemeleri uygulamalarında kullanılan incelemeleri tasvir için uygun değildir. ${ }^{31}$ Zirâ DNA analizi, dört farklı gen analizi yöntemlerinden (fenotip analizi, kromozom analizi, protein kimyasal analiz gen analizi) sadece birisidir ${ }^{32}$ ve gen analizlerinin yalnızca bir kısmını oluşturmaktadır ${ }^{33}$. “Gen analizi, insanın genetik özelliklerinin belirlenmesine hizmet eden bir yöntemdir." 34 Gerçekten de genom, bir insanın kalıtımsal bilgilerini içeren bir bütün ("Gametlerde bulunan kromozomlar." 35 ); gen ise DNA'nın kodlanmış kısmında yer alan unsurlar olup (“Íçinde bulunduğu hücre veya organizmaya özel bir etkisi olan, kuşaktan kuşağa ve hücreden hücreye geçen kalıtımsal öge." $\left.{ }^{36}\right)$, "bir organizmaya ait tüm genetik bilgiyi içerirler" ${ }^{37}$. Şu hâlde iz bilimi ve ceza muhakemesi dolayısıyla adlî tıp uygulaması, ne genom ne de genlerle ilgilenmekte, incelemeleri sadece karşılaştırma yoluyla kimliklendirme yapılabilecek dar bir alanla sınırlı tutmaktadır. Bu nedenle genom, gen analizi vs. kavramları, amacı aşan kavramlardır ve ceza muhakemesi hukukunun terminolojisi dışındadır.

Moleküler genetik araştırmalar ve DNA araştırmaları kavramalarına yönelik aşağıda aktarılan tanımlamalardan ise, DNA incelemesinin moleküler genetik bir araştırma olduğu sonucuna ulaşılmakta ve sıklıkla birbirinin yerlerine eşanlamlı

28 BGH NJW 1990, s. 2328; LG Heilbronn NJW 1990, s. 784.

29 Centel/Zafer, CMH, s. 304; Yenisey/Nuhoğlu, CMH, s. 653; Özbek/Diğerleri, CMH, s. 532 vd.; Şahin/ Göktürk, CMH II, s. 85.

30 Ayrıntılı açıklamlalarla bu kavramdan yana Klumpe, s. 13; aynı şekilde Özbek, son erişim: 6.1.2017; genel olarak daha çok bu kavramı tercih eden Meyer-Goßner/Schmitt, StPO, § 81e s. 310 dev; Volk/Engländer, Grundkurs StPO, s. 69 vd.; Roxin/Schünemann, Strafverfahrensrecht, s. 271 vd.; Kindhäuser, Strafprozessrecht, s. 94; Beulke, Strafprozessrecht, s. 148 vd.; Eisenberg, Beweisrecht der StPO, s. 676; Ünver/Hakeri, CMH, s. 474.

31 Krş. Klumpe, s. 12, 13.

32 Büyükay, AÜEHFD C IX, S. 3-4 (2005), s. 360, 361.

33 Klumpe, s. 13; Büyükay, AÜEHFD C IX, S. 3-4 (2005), s. 360, 361; Mahmutoğlu, s. 1, son erişim: 15.01.2017; Özbek, CHD, Nisan 2007, Sayı: 1, s.47, 49.

34 Mahmutoğlu, s. 1, son erişim: 15.01.2017.

35 Türk Dil Kurumu, iç: http://www.tdk.gov.tr, son erişim: 5.12.2016.

36 Türk Dil Kurumu, iç: http://www.tdk.gov.tr, son erişim: 5.12.2016.

37 Mahmutoğlu, s. 1, son erişim: 15.01.2017; Özbek, CHD, Nisan 2007, Sayı: 1, s.47. 
olarak kullanıldıkları görülmektedir. Öyle ki Ünver/Hakeri" "DNA incelemesi olarak da adlandirllan moleküler genetik incelemelerden" bahsetmektedirler. Kindhäuser ${ }^{39}$ AlmCMK m. 81e anlamında DNA analizini, ceza muhakemesinde moleküler genetik kimlik şablonunun (profilin) çıkarılması amacıyla hücreler üzerinde moleküler genetik araştırmalarda bulunmak olarak; yine DNA Verileri ve Millî DNA Veri Bankası Kanunu Tasarısı, ikinci maddesinin birinci fikrasının e bendi DNA analizini, "DNA profili elde etmek amacıyla DNA örneği üzerinde yapılan bilimsel test" olarak nitelendirmektedir. Bunun yanında Ceza Muhakemesinde Beden Muayenesi, Genetik Incelemeler ve Fizik Kimliğin Tespiti Hakkında Yönetmelik' in "moleküler genetik inceleme" başl1kl1 3. maddesi moleküler genetik incelemeyi, "Gereken tür ve miktardaki biyolojik materyali kullanarak, kişiyi diğer kişilerden ayıran ve kalıtım kurallarına uygun olarak aktarılan hastalık dışındaki özelliklerinin moleküler düzeyde araştırılması" olarak tanımlamaktadır. Tüm bu açıklamalardan sonra DNA incelemesini çok genel bir ifadeyle, moleküler genetik bir araştırma olarak tanımlamak hatalı olmayacaktır.

Biz konuyu daha kapsamlı ve net bir şekilde ortaya koyduğundan DNA analizi terimine öncelik vermekten yanayız. Bununla birlikte DNA analizi kavramının bir üst kavram olduğu ve kodlanmamış kısım kadar kodlanmış kısmın analizini de içerebileceğini gözden uzak tutmamak gerekir. ${ }^{40}$ Buna karşın ceza muhakemesi kapsamında yapılan analiz amaç ve kapsam bakımından oldukça sınırlıdır ve bu nedenle de kendine has bir özellik göstermektedir. Öyle ki, ceza muhakemesinde DNA analizi ceza muhakemesi tedbiri olarak suçların aydınlatılması kapsamında sadece kimliklendirmeye hizmet etmekte, bundan daha fazlasıyla ilgilenmemektedir. $\mathrm{Bu}$ nedenle de araştırmalar bu amaca hizmet edecek olan DNA'nın sadece kodlanmamış kısmıyla sınırlı tutulmaktadır. Bu amaçsal farklılıklar ve sınırlamalar ceza muhakemesinde yapılan DNA incelemesinin, genel anlamda DNA incelemelerinden de farklı olduğu sonucunu ortaya koymaktadır. Ceza muhakemesini ilgilendiren aslında sadece adî̂ DNA analizidir. Şu hâlde, adlî DNA analizinde geniş anlamda DNA analizi ya da moleküler genetik araştırma değil, sadece suçların aydınlatılması ve sahibinin kimliklendirilmesi amacıyla DNA'nın kodlanmamış alanında yapılacak, dar kapsamlı bir araştırma söz konusudur. Bu bağlamda yanlış

38 Ünver/Hakeri, CMH, s. 474.

39 Kindhäuser, Strafprozessrecht, s. 94.

40 Krş. aynı neticede Klumpe, s. 13, ancak yazar adlî DNA analizi kavramını değil, DNA parmak izi kavramını kullanmayı tercih etmektedir. 
anlamaları önlemek ve geniş anlamda DNA analizleri kavramına karşı gelişebilecek önyargıların da önüne geçebilmek açısından, en yerinde olanı bize göre "adlî $\boldsymbol{D} \boldsymbol{N} \boldsymbol{A}$ analizi" $^{41}$ terimidir. DNA Verileri ve Millî DNA Veri Bankası Kanunu Tasarısı'nın da ceza yargılaması ile alâkalı DNA analizlerini "adlî amaçlı DNA analizi” olarak nitelendirdiğine işaret etmek gerekmektedir. Bu çalışmada özellikle kavramların aslına uygun aktarımının önemli olduğu durumlarda yer yer moleküler genetik araştırmalar ve DNA analizi, yer yer de adlî DNA analizi kavramları kullanılmıştır.

Tüm bu açıklamalardan sonra ceza muhakemesinde adlî DNA analizi, kişiyi diğerlerinden ayırmaya yarayan bir DNA kimlik şablonu (DNA profili) elde ederek kimliklendirmede bulunabilmek amacıyla DNA üzerinde (moleküler genetik) inceleme yapılması olarak tanımlanabilir. Adlî DNA analizinde kural olarak, biyolojik örneklerden DNA ayrıştırılarak karşılaştırmaya esas teşkil eden bölgeler binlerce kez çoğaltılarak görünür hâle getirilmekte ve ortaya çıkan bantlar (barkodlar) bilgisayar aracılı̆̆ıyla sayısal değerlere dönüştürülüp, DNA profil karşılaştırması yapılmaktadır. ${ }^{42}$ Elde edilen DNA profilleri, "kişinin DNA'sına birebir karşılık gelen şifrelenmiş, numara dizileridir" ${ }^{43}$. Dolayısıyla burada "fotoğraf benzeri bir tablo"44 elde edilmektedir ve suçların aydınlatılmasında kullanılacak olan bu biyolojik örnekler değil, tam tersi bu tablo olacaktır. ${ }^{45}$

\subsection{Ceza Muhakemesinde Adlî DNA Analizlerinin Hukukî Niteliği}

Türk $^{46}$ ve Alman $^{47}$ ceza muhakemesi hukukunda baskın görüş, adlî DNA analizlerinin koruma tedbiri olduğu yönündedir. Bunun yanında DNA analizinin Alman Ceza Muhakemesi Kanunu'nda 1. Kitap, Bilirkişiler ve Keşif başlıklı 7. kısımda (m. 72 - 93); Türkiye'de ise 1. Kitap, Tanıklık, Bilirkişi İncelemesi ve Keşif başlıklı Üçüncü Kısımda, Gözlem Altına Alınma, Muayene, Keşif ve Otopsi başlıklı Üçüncü Bölümde yer aldığı görülmektedir.

41 Aynı neticede ayrıca diğer eleştiriler için Altendorfer, s. 23, 24; Burr, s. 23, 24.

42 Elmas/Ersoy, s. 112; DNA analizinde profil çıkarma yöntemleri hususunda ayrıca Öztürk, s. 5 vd.

43 Öztürk, s. 5.

44 Yenisey/Nuhoğlu, CMH, s. 654.

45 Yenisey/Nuhoğlu, CMH, s. 654.

46 Yenisey/Nuhoğlu, CMH, s. 654; Özbek/Digerleri, CMH, s. 286 vd.; Özbek, son erişim: 6.1.2017; Özbek, CHD, Nisan 2007, Sayı: 1, s. 55; Mahmutoğlu, s. 1, son erişim: 15.01.2017; Centel/Zafer, CMH, s. 304, dipnot: 283, her ne kadar koruma tedbirlerine ilişkin kısımda DNA analizlerini doğrudan doğruya ifade etmeseler de, işlemin tedbir niteliğini de ayrıca reddetmemektedirler.

47 Temel haklara müdahâlede bulununan zorlayıcı tedbirler kapsamında Volk/Engländer, Grundkurs StPO, s. 69 vd.; Roxin/Schünemann, Strafverfahrensrecht, s. 227 vd., 271 vd.; Kindhäuser, Strafprozessrecht, s. 94 vd.; Beulke, Strafprozessrecht, s. 148 vd. 
5271 sayılı Ceza Muhakemesi Kanunu'nun Dördüncü Kısmında yer alan “koruma tedbiri"48, "kural olarak, ceza muhakemesinde karar verme yetkisini haiz olan yetkililer tarafindan, gecikmede sakınca bulunan durumlarda, geçici olarak başvurulan ve hükümden önce bazı temel hak ve özgürlüklere müdahaleyi gerektiren önlemler"49 anlamında olup; ceza muhakemesinin hızl bir şekilde yürütülmesini sağlamak, delil elde etmek ve elde edilen delillerin korumak, şüpheli veya sanığ muhakeme sırasında veya hükmün infazı için hazır bulundurmak; ${ }^{50}$ dolayısılla ceza muhakemesinin gerçekleştirilmesi veya muhakeme sonunda verilecek kararların kâğıt üzerinde kalmamasını ve muhakeme masraflarının karşılanmasını să̆lamak ${ }^{51}$ amacıyla başvurulan ceza muhakemesi tedbirleridir. Bu amacı gerçekleştirmeye yönelik olarak koruma tedbirleri, henüz hükümden önce hukuken korunan çeşitli bireysel temel hak ve özgürlüklere (kişi özgürlüğü, vücut bütünlüğü veya özel hayatın gizliliği vs.) müdahale etmekte ve bunları sınırlandırmaktadır. ${ }^{52}$

DNA analizinin, güvenilir bilimsel yöntemlerle elde edilen, suçların aydınlatılması ve ceza yargılamasının hukuka uygun bir şekilde makul bir sürede sonlandırılmasına yönelik deliller (DNA profilleri) ortaya koyduğundan şüphe yoktur. Analiz yapılması kararının, analiz sonrası elde edilen profillerin korumas1, toplaması ve yargilamada hazır bulundurulmasından başka bir amacı yoktur. Bunun yanında analizin özel hayatın korunması, kişisel verilerin korunması gibi bazı temel haklara saldırıda bulunduğu da sabittir. Tüm bu açıklamalar ışığında adlî DNA analizlerini koruma tedbiri olarak nitelendirmek isabetsiz olmayacaktır. Bunun haricinde adlî DNA analizlerinin koruma tedbirlerinin yasall $^{53}$, geçicilik $k^{54}$, karara dayanma ${ }^{55}$ ve

48 Tartışmalı olmakla birlikte koruma tedbirleri kavramı öğretide yaygın olarak kullanılmaktadır: Öztürk/ Diğerleri, CMH, . 437; Centel/Zafer, CMH, s. 330; Yenisey/Nuhoğlu, CMH, s. 304; Özbek/Digerleri, CMH, s. 283.

49 Öztürk/Diğerleri, CMH, s. 437.

50 Şahin, CMH I, s. 269.

51 Öztürk/Diğerleri, CMH, s. 437.

52 Şahin, CMH I, s. 269; Öztürk/Diğerleri, CMH, s. 439 vd.;ayrıntılı bkz. Arslan, iç: TBBD 2015 (120) s. 155 vd.

53 Şahin, CMH I, s. 273 vd.; Öztürk/Diğerleri, CMH, s. 440.

54 Şahin, CMH I, s. 273 vd.; Öztürk/Diğerleri, CMH, s. 440.

55 Şahin, CMH I, s. 273 vd.; Öztürk/Diğerleri, CMH, s. 440. 
ölçülülük vs. gibi bazı ortak özelliklerine de haiz oldukları da ortadadır. ${ }^{56}$

Koruma tedbiri teşkil eden adlî DNA incelemelerinin bir tedbir olarak bağımsız bir yapısı olmadığ $1^{57}$ ve "karma" 58 nitelikte olduğu ifade edilmektedir. Buna göre DNA analizinin kendine özgü bir niteliği ve sanıktan alınan "vücut materyali" ve olay yerinden elde edilen “iz materyali”nin analizi ile bağlı olmak üzere iki farklı yönü bulunmaktadır. DNA analizleri bir yönüyle beden muayenesi koruma tedbirinin bir parçası, diğer bir yönüyle ise keşif veya olay yeri incelemesinin bir uzantısı teşkil etmektedir. Beden muayenesi, kişinin vücut boşluklarında veya iç organlarında veyahut da vücut sıvılarında tıbbi yöntem ve araçlarla özelliklerinin incelenerek delil aranması anlamına gelmekte, bu bağlamda beden muayenesi yoluyla elde edilen vücut materyallerinin DNA-Analizine tabi tutulması bu yöntemin sadece bir yönünü oluşturmaktadır. Bu nedenle yöntem beden muayenesi koruma tedbirinin bir parçası olup, bilirkişi incelemesi ile bir arada uygulanır. Bunun haricinde olay yerinden elde edilen iz materyalleri üzerinde DNA-Analizi yapılması açısından yöntemin, beden muayenesi koruma tedbirinden ayrılarak daha çok keşif ve/veya olay yeri incelemesi sonrasında başvurulan bir bilirkişi incelemesi niteliğine büründüğü ifade edilmektedir. Bu bağlamda DNA-Analizi hâkim bakımından bir keşif, analizi uygulayacak doktor veya uzman (yetkili) bakımından bir bilirkişi incelemesidir. ${ }^{59}$

\subsection{Adlî DNA İncelemelerinin Temel Hakları İhlal Etmesi Sorunu}

Adlî DNA incelemeleri özellikle insan haysiyetinin dokunulmazlığı başta olmak üzere, vücut bütünlüğü hakkının korunması, temel kişilik hakları ve kişisel bilgilerin geleceğini belirleme hakkı (bilgiler üzerinde özerklik veya bilgilendirme özerkliği) yani kişisel verilerin korunmasını isteme hakkı kapsamında tartışma konusu olmuştur. Aşağıda üzerinde DNA analizi yapılacak örneğin alınabilmesi için vücut

56 Mahmutoğlu, s. 2, son erişim: 15.01.2017; Özbek, son erişim: 6.1.2017, koruma tedbirlerinin sahip olduğu özellikler ve koşullardan, belli bir suç şüphesinin gerekliliği, oranlılık ilkesinin aranması, temel haklara ağır bir müdahâle oluşturduğu için tüm aşamalarda hâkim kararının aranması, yasayla düzenlenme zorunluluğu gibi koşulların DNA analizi için de geçerli olduğunu ifade etmekte; bunun yanında DNA analizi ile koruma tedbirlerinin özellikle zorlama, geçici olma, gecikmede tehlike bulunması gibi unsurlar bakımından birbirlerinden ayrıldıklarını, ancak tüm bu hususların, DNA analizini koruma tedbiri olmaktan çıkarmayacağını ifade etmektedir. Ayrıca kendine özgü uygulanma koşullarının varlığı nedeniyle DNA analizinin farklı bir hukukî niteliğe bürünmesine neden olduğunu ve bu nedenle de vücudun muayenesi koruma tedbirinden ayrı madde/maddelerde düzenlenmesi gerektiğini dile getirmektedir.

57 Batur, TBBD 2016 (126), s. 83; Özbek, son erişim: 6.1.2017; Özbek, CHD, Nisan 2007, Sayı: 1, s. 55; Mahmutoğlu, s. 2, son erişim: 15.01.2017.

58 Centel/Zafer, CMH, s. 304; Özbek, son erişim: 6.1.2017.

59 Özbek, son erişim: 6.1.2017; aynı şekilde Özbek, CHD, Nisan 2007, Sayı: 1, s. 55, 56. 
dokunulmazlığına müdahale edilmesi gerektiğinden öncelikle vücut bütünlüğünün dokunulmazlığı hakkına, bunun ardından insan haysiyetinin dokunulmazlığı, özel hayat ve bilgilendirme özerkliği yani kişisel verilerin korunmasını isteme hakkına müdahâle hususlarına değinilecektir.

\subsubsection{Vücuttan Biyolojik Örnek Alınması Suretiyle Temel Hak İhlali?}

Vücuttan kan örneği alınmasının vücut bütünlüğünün korunması temel hakkını ihlal edip etmediği Almanya' da Federal Anayasa Mahkemesi’ne taşınmış bir konudur. Alman Federal Anayasa Mahkemesi ${ }^{60}$ konuya ilişkin kararında, icrasının şekli itibariyle çok hafif derecede bir etkisinin olması ve bu nedenden dolayı da ilgilisinden beklenebilecek nitelikte bir yükümlülüğ̈̈n, vücut bütünlüğüne bir saldırı olarak kabul edilemeyeceğini ifade etmiştir. ${ }^{61}$ Öğretide ${ }^{62}$ mevzuatta yer alan, kan örneği alınmas1 amacıyla icrâ edilen işlem tehlikeden ve risklerden uzak, orantılı, bu bağlamda da anayasaya uygun bir işlem olarak kabul edilmektedir.

Vücut bütünlügünün dokunulmazlığı hakkı Türkiye Anayasası m. 17 II kapsamında korunmakta; ancak birçok temel hak gibi vücut bütünlüğünün dokunulmazlığı hakkı da anayasal koşullara uyularak sınırlandırılabilir kabul edilmektedir. Anayasa Mahkemesine göre Anayasa'da güvence altına alınan temel hak ve özgürlüklerin korunması veya Anayasa'nın devlete bir görev olarak yüklediği millî güvenliğin, kamu düzeninin korunması ya da suç işlenmesinin önlenmesi gibi nedenlerle temel haklar sınırlandırılabilecektir. Anayasa insanı tek başına varlık gösteren değil, topluluk içerisinde yaşayan bir birey olarak kabul ettiğinden, özellikle suçların aydınlatılması vs. gibi sebeplerle bir “kamu yararının"63 bulunması durumunda, temel haklarına yönelik bazı sınırlamalara katlanmasını bireyden

60 BVerfG 5, s. 15.

61 BVerfG 17, s. 115

62 Neuser, s. 80; Klumpe, s. 162, 164; Pieroth/Jarass, Grundgesetz, m. 2. pn. 87; Münch/Kunig-Kunig, GGK I, m. 2 pn. 65; OLG Köln NStZ 1986, s. 234.

63 Anayasa Mahkemesi E: 2014/196, K: 2015/103, T: 12.11.2015, RG Tarih - Sayı: 16.12.2015 - 29564, iç: http://kararlaryeni.anayasa.gov.tr/Karar/Content/75a9113f-cb28-4ec6-b66a-2b99c20ac20b?higllightText =dna\&excludeGerekce=False\&wordsOnly=False, son erişim: 29.11.2016: Türk Anayasa Mahkemesi kamu yararı kavramını şu şekilde açıklamaktadır: “Anayasa Mahkemesince 'kamu yararı'konusunda yapılacak inceleme, kanunun kamu yararı amacıyla yapıllp yapılmadığının araştırılmasıyla sinırlıdır [...] kamu yararı, bireysel, özel çıkarlardan ayrı ve bunlara üstün olan toplumsal yarardır. Kamu yararı düșüncesi olmaksızın, yalnız özel çıkarlar için veya yalnız belli kișilerin yararına olarak kanun hükmü konulamaz. Böyle bir durumun açık bir biçimde ve kesin olarak saptanması hâlinde, söz konusu kanun hükmü Anayasa 'nın 2. maddesine aykırı düşer. Açıklanan ayrık hâl dışında, bir kanun hükmünün ülke gereksinimlerine uygun olup olmadiğ ve hangi araç ve yöntemlerle kamu yararının sağlanabileceği bir siyasî tercih sorunu olarak kanun koyucunun takdirinde olduğundan, bu kapsamda kamu yararı değerlendirmesi yapmak anayasa yargısıyla bağdaşmaz." 
beklemektedir. Anayasa Mahkemesi ${ }^{64}$ sınırlama yapılırken temel hak ve özgürlüklerin sınırlandırılması rejimini belirleyen Anayasa'nın 13. maddesi uyarınca temel hakların yalnızca kanunla ve demokratik bir toplumda gerekli olduğu ölçüde sınırlanabileceğini; getirilen bu sınırlamaların, hakkın özüne dokunamayacă̆ı gibi Anayasa'nın sözüne ve ruhuna, demokratik toplum düzeninin gereklerine ve ölçülülükk ilkesine ${ }^{65}$ aykırı olamayacağını kabul etmektedir. ${ }^{66}$ En nihayetinde sınırlama getiren yasal düzenlemenin belirlilik ilkesine ${ }^{67}$ uygun olması gerekir. Alman Anayasa Mahkemesi de benzer şekilde sınırlamanın kanun tarafından yapılması, sınırlamaya dayanak kamu yararının ağır basması, orantılılık ilkesine

64 Anayasa Mahkemesi E: 2014/180, K: 2015/30, T: 19.3.2015, RG Tarih-Sayı: 3.4.2015-29315, iç: http:// kararlaryeni.anayasa.gov.tr/Karar/Content/eb0ec 514 - e 01 c - 47 ba - 86 be dadfd0c0c2b3?higllightText $=\mathrm{dna} \% 20$ analizi\&excludeGerekce $=$ False \&wordsOnly $=$ False, son erişim: 29.11.2016.

65 Anayasa Mahkemesi E: 2014/196, K: 2015/103, T: 12.11.2015, RG Tarih - Sayı: 16.12.2015 - 29564, iç: http://kararlaryeni.anayasa.gov.tr/Karar/Content/75a9113f-cb28-4ec6-b66a-2b99c20ac20b?higllightText $=$ dna\&excludeGerekce=False\&wordsOnly=False, son erişim: 29.11.2016:

“Ölçülülük amaç ve araç arasında hakkaniyete uygun bir dengenin bulunması gereğini ifade eder; ölçülülük, aynı zamanda yasal önlemin sınırlama amacına ulaşmaya elverişli olmalt, amaç ve aracın ölçülü bir oranı kapsamasını ve sınırlayıcı önlemin demokratik toplum düzeni bakımından zorunluluk taşımasını da içeren bir ilkedir.; Anayasa Mahkemesi E: 2014/196, K: 2015/103, T: 12.11.2015, RG Tarih - Say1: 16.12.2015 - 29564, iç: http://kararlaryeni.anayasa.gov.tr/Karar/Content/75a9113f-cb28-4ec6b66a-2b99c20ac20b?higllightText=dna\&excludeGerekce=False\&wordsOnly=False, $\quad$ son $\quad$ erişim: 29.11.2016, Kanun koyucunun düzenlemeler yaparken hukuk devleti ilkesinin bir gereği olan ölçülülük ilkesiyle bağlı olduğunun belirtildiği kararlarında ölçülülük ilkesi şu şekilde açıklanmaktadır: Ölçülülük ilkesi “'elverişlilik', 'gereklilik' ve 'orantılılık' olmak üzere üç alt ilkeden oluşmaktadır. 'Elverişlilik', başvurulan önlemin ulaşılmak istenen amaç için elverişli olmasını, 'gereklilik' başvurulan önlemin ulaşılmak istenen amaç bakımından gerekli olmasını, 'orantılılık' ise başvurulan önlem ve ulaşılmak istenen amaç arasında olması gereken ölçüyü ifade etmektedir. Bir kurala uyulmaması nedeniyle kanun koyucu tarafindan öngörülen yaptırım ile ulaşılmak istenen amaç arasında da 'ölçülülük ilkesi'gereğince makul bir dengenin bulunmasi zorunludur."

66 Anayasa Mahkemesi E: 2014/180, K: 2015/30, T: 19.3.2015, RG Tarih-Sayı: 3.4.2015-29315, iç: http:// kararlaryeni.anayasa.gov.tr/Karar/Content/eb0ec 514 - e 01 c - 47 ba - 86 be dadfd0c0c2b3?higllightText $=$ dna $\% 20$ analizi\&excludeGerekce $=$ False\&wordsOnly $=$ False, son erişim: 29.11.2016; krş. Anayasa Mahkemesi E: 2014/196, K: 2015/103, T: 12.11.2015, RG Tarih - Say1: 16.12.2015 - 29564, iç: http://kararlaryeni.anayasa.gov.tr/Karar/Content/75a9113f-cb28-4ec6-b66a-2b99c 20ac20b?higllightText=dna\&excludeGerekce=False\&wordsOnly=False, son erişim: 29.11.2016.

67 Anayasa Mahkemesi E: 2014/122, K: 2015/123, T: 30.12.2015, RG Tarih-Sayı: 01.03.2016 - 29640, iç: http://kararlaryeni.anayasa.gov.tr/Karar/Content/004ab030-da $02-462$ b- $9990-$ 84cad78525c9?higllightText=kişisel\%20veri\&excludeGerekce=False\&wordsOnly=False, son erişim: 28.11.2016:

“Anayasa'nın 2. maddesinde, Türkiye Cumhuriyeti bir hukuk devleti olarak nitelendirilmiștir. Hukuk devletinin temel ilkelerinden biri “belirlilik”tir. Bu ilkeye göre, yasal düzenlemelerin hem kişiler hem de idare yönünden herhangi bir duraksamaya ve kuşkuya yer vermeyecek şekilde açık, net, anlaşılır, uygulanabilir ve nesnel olması, ayrıca kamu otoritelerinin keyfi uygulamalarına imkân tanımamast gerekir. Belirlilik ilkesi, hukuksal güvenlikle bağlantıl olup birey, yasadan belirli bir kesinlik içinde, hangi somut eylem ve olguya hangi hukuksal yaptırımın veya sonucun bağlandığını bilmelidir. Birey ancak bu durumda kendisine düşen yükümlülükleri öngörebilir ve davranışlarını düzenleyebilir. Hukuk güvenliği, normların öngörülebilir olmasını, bireylerin tüm eylem ve işlemlerinde devlete güven duyabilmesini, devletin de yasal düzenlemelerde bu güven duygusunu zedeleyici yöntemlerden kaçınmasını gerekli kılar." 
uygun hareket edilmesi, ${ }^{68}$ kamusal yarar ne kadar ağır basarsa bassın hakkın çekirdeğine kesinlikle dokunulmamas ${ }^{69}$, belirlilik ilkesi gereklerine uygunluk, açık ve anlaşılır olma ${ }^{70}$ vs. gibi ilkeleri anmaktadır.

Bu açıklamalar 1şı̆̆ında DNA analizi için vücuttan başta kan olmak üzere biyolojik örnek alınması işlemi bakımından şunu belirtmek gerekir: Her ne kadar kan örneği alınması işleminde, küçük bir iğne yoluyla damar çeperine girilmesi ve oradan 2-3 cl kan örneği alınması söz konusu olsa da, burada vücut bütünlüğüne yönelik hiç bir müdahalenin bulunmadığı ve sağlığa yönelik hiç bir tehlikenin doğmadığı iddia edilemez. ${ }^{71}$ Dolayısıyla özellikle vücuttan kan alınması vücut bütünlüğünü ihlal eden bir müdahaledir. Öte yandan günümüzde enjeksiyon yardımıyla kan alma yöntemine alternatif daha hafif yöntemler yardımıyla da DNA örneği elde edilebilmektedir. Gerçekten de yanaktan sürüntü alımı, köklü saç, tükürük alma vs. gibi vücuda doğrudan saldırı sayılmayacak yöntemlerle de örnek alımı mümkündür. Hatta bunlardan yanaktan sürüntü alımı kolay ve ucuz, bu nedenle de en çok tercih edilen yöntemler arasında sayılmaktadır. ${ }^{72}$ Gerçekten de bu işlemler sırasında vücut bütünlüğüne yönelik esaslı bir müdahalede bulunulmamaktadır. Kan örneği almakla karşılaştırıldığında, bu tür yöntemlerin temel hakka saldırı bakımından daha hafif araç teşkil ettiklerinden şüphe yoktur. Ayrıca kan örneği alınması dahil tüm bu müdahalelerin, bir hukuk devletinde ilgilisinden beklenmeyecek derecede ağır sonuçlar doğuran veya katlanılması güç yükümlülükler getirmedikleri ortadadır. Suçların aydınlatılmasına hizmet eden işlemler sırasında tıbbî sanat uygulamaları standartlarına uyulması ve sağlığa yönelik bir tehlike yaratılmaması koşulu ile ilgilisinden işlem sırasında etkin rol oynamasını değil, sadece pasif kalmasını bekleyen az bir miktarda kan alma işlemi veya diğer örnek alma işlemlerini anayasaya uygun kabul etmek gerekir. Ancak burada başvurulacak alternatif yöntemlerden en hafif aracı seçmek orantılılık ilkesinin temel koşulu olduğundan, yanaktan sürüntü vs. gibi hafif bir yönteme başvurulacakken enjektörle kan örneği alınması yöntemine başvurulmaması temel hakkın en yüksek düzeyde korunmasına hizmet edecektir.

BVerfG StV 2001, s. 380; BVerfG 65, s. 44; BVerfG NJW 2004, s. 1001.

BVerfG 34, s. 245; BVerfG 80, s. 373.

BVerfG 65, s. 44; BVerfG 92, s. 197.

Krş. Özbek, CHD, Nisan 2007, Sayı: 1, s. 63, vücut dokunulmazlığının ihlâlinin ortada olduğunu ancak müdahâlenin yasal düzenleme yoluyla hukuka uygun hâle getirilebileceğini ifade etmektedir; Özbek, son erişim: 6.1.2017; aynı şekilde Mahmutoğlu, s. 4, son erişim: 15.01.2017; Yenisey/Nuhoğlu, CMH, s. 654, konu kanunda düzenlendiğinden anayasaya aykırılık görmemektedirler. 


\subsubsection{Adlî DNA Analizi Yapılması Suretiyle Temel Hak İhlali?}

Sadece vücuttan örnek alınması değil, alınan örnekler üzerinde adlî DNA analizlerinin yapılması, özellikle insan haysiyeti, genel kişilik hakları ve Alman hukukundaki ifadesiyle kişisel bilgilerin geleceğini belirleme hakkı (bilgiler üzerinde özerklik veya bilgilendirme özerkliği hakkı), Türk hukukundaki ifadesiyle kişisel verilerin korunmasını isteme hakkı çerçevesinde hukukî sorunlar yaratmaktadır. Aşağıda bu hususlardaki tartışmalara yer verilecektir.

\subsubsection{Adlî DNA analizleri ve insan haysiyetinin dokunulmazlığı i) İnsan haysiyetinin dokunulmazlığı ilkesi}

Alman Anayasası'nın 1. maddesine öngörülen insan haysiyetinin dokunulmazlığ ilkesi ya da başka bir ifadeyle insan özsaygınlığına dokunma yasă̆l, her bir bireyin bireyselliğine saygı duyulması ve hayatının en gizli alanına dokunulmamasını öngörmekte; ${ }^{73} \mathrm{~m}$. 1 I 2 devlete insan haysiyetini koruma yükümlülüğü getirmektedir. Alman Federal Anayasa Mahkemesi'ne ${ }^{74}$ göre insan haysiyeti kavramı, insanı özgür ve belirleme özerkliğine sahip bir canll olarak görmekte ve böyle özgür ve özerk bir insan doğasından ("insan resmi" Menschbild) yola çıkmaktadır. Ayrıca insan, dünya üzerinde tek başına bir canlı olarak değil, tersine topluluk içerisinde yaşayan ve bu topluluğa karşı yükümlülükleri olan bir kişiliktir. ${ }^{75}$ Alman Federal Anayasa Mahkemesi özne niteliğindeki bireyin öznellik niteliğinin ihlal edilmesini, geliştirdiği "nesne formülü” ile açıklamaktadır. Buna göre kişinin öznelliği, bir insanın "devletin basit bir nesnesi" hâline dönüştürülmesiyle ihlal edilmiş olacaktır. ${ }^{76}$ Insan nesne değil, bir özne ${ }^{77}$ olup, toplumun, eşit haklara sahip bir üyesidir. ${ }^{78}$ Şu hâlde insan haysiyetinin dokunulmazlığı, insanın basit bir objeye indirgenemeyeceğ $i$ anlamına gelmektedir. ${ }^{79}$ İnsan haysiyeti insanın sosyal konumu, dış görünüşü vs. belirleyici olmadan, her

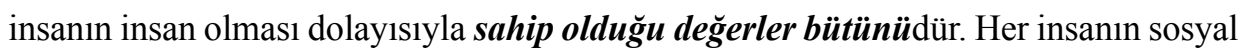
bir değeri vardır ve herkes bunun korunmasını talep etme hakkına sahiptir. ${ }^{80}$ 
İnsan haysiyetinin dokunulmazlığı aynı zamanda insanın basit bir bilgi kaynağına indirgenmesini de yasaklamaktadır. ${ }^{81}$ Bireyin, vücutsal engelleri, eksiklikleri vs. hakkında bilgi verme zorunda olmaması, insan haysiyetinin korunmas1 kapsamında değerlendirilmektedir. ${ }^{82}$ Ceza yargılaması hukukunda, devletin ne pahasına olursa olsun ceza yargılaması yapma hakkı bulunmamaktadır. ${ }^{83}$

Benzer bir durum Türk anayasa hukuku için de geçerlidir. T.C. Anayasası m. 17 III "kimse insan haysiyetiyle bağdaşmayan bir [...] muameleye tâbi tutulamaz." emri ile insan haysiyetine dokunma yasağı getirmiştir. Ayrıca Anayasa m. 12 de, herkesin kişiliğine bağll, dokunulmaz, devredilmez, vazgeçilmez temel hak ve hürriyetlere sahip olduğunu ancak, temel hak ve hürriyetlerin, kişinin topluma, ailesine ve diğer kişilere karşı ödev ve sorumluluklarını da ihtiva ettiğini belirtmektedir. Anayasa m. 5 içerisinde sayılan Devletin temel amaç ve görevlerinden bir kısmı da, kişilerin ve toplumun refah, huzur ve mutluluğunu sağlamak; kişinin temel hak ve hürriyetlerini sınırlayan engelleri kaldırmaya, insanın maddî ve manevî varlı̆̆ının gelişmesi için gerekli şartları hazırlamaya çalışmaktır. Dolayısıyla insan haysiyetini korumak Devlete bir yükümlülük olarak yüklenmiştir.

Anayasa Mahkemesine ${ }^{84}$ göre, insan haysiyeti kavram1 "insanın ne durumda, hangi şartlar altında bulunursa bulunsun sirf insan oluşunun kazandirdı̆̆ değerin tanınmasını ve sayılmasını" anlatır. "Bu öyle bir davranış çizgisidir ki ondan aşağı düşünce, muamele ona muhatap olan insanı insan olmaktan çıkarır. Insan haysiyeti kavramını, toplumların kendi görenek ve geleneklerine ve topluluk kurallarına göre saygıya değer olabilmesi için bir insanda bulunmasını zorunlu gördükleri niteliklerle karıştırmamak gereklidir. Bu kavramın gelişmesi ve yerleşmesi çok uzun bir zaman almış; prangabentlik, teşhir, boyunduruk, dayak gibi cezaların kaldırılması bu sayede mümkün olabilmiştir." ${ }^{\text {"5 }}$ Ünver' ${ }^{86}$ göre insan onuru kavramının gereklerinden biri "insan haklarının önceliğidir". Yazara göre insan onuru "bir

81 BVerfG 65, s. 48.

82 Neuser, s. 85.

83 BGHSt 38, s. 220.

84 Resmi Gazete Tarih/Say1 27.6.1967/12632, E: 1963/132, K: 1966/29, T: 28/6/1966, iç: http://kararlaryeni. anayasa.gov.tr/Karar/Content/b95ec65c-f13d-4bcd-a586-4f2b970f58c3?excludeGerekce=False\&wordsO nly=False, son erişim: 12.12 .2016 .

85 Resmi Gazete Tarih/Say1: 27.6.1967/12632, E: 1963/132, K: 1966/29, T: 28/6/1966, iç: http://kararlaryeni. anayasa.gov.tr/Karar/Content/b95ec65c-f13d-4bcd-a586-4f2b970f58c3?excludeGerekce=False\&wordsO nly=False, son erişim: 12.12.2016. 
cephesiyle insan haklarının asli ve öncelikli oluşu vurgusunu ifade etmekte olup, insan haklarınin en yüksek zirvesi kabul edilmekte, ikinci bir cephesi ise alan olarak az ancak ă̆ır basan bir cephesidir ve bundan amaç olduğu kastedilir." ${ }^{87}$

\section{ii) Adlî DNA Analizi Yoluyla İnsan Haysiyetini İhlal?}

DNA analizinin insan haysiyetinin dokunulmazlığı yasağını ihlal etmediği konusunda, Türk ${ }^{88}$ ve Alman ${ }^{89}$ hukukunda genel bir kabul olduğu görülmektedir. Bu görüşlere göre moleküler genetik incelemelerle, DNA'nın kodlanmamış kısmında bulunan ve sadece kişileri birbirinden ayırmaya yarayan temel unsurların tespit edildiği, anılan bu alanda kural olarak kalıtımsal özelliklere ait veriler, karakteristik özellikler ya da kalıtımsal hastalıklara ilişkin verilerin yer almadığı ifade edilmektedir. Bunun yanında zorunlu ceza muhakemesi tedbiri yoluyla bir insanın, tüm genomlarının kategorize edilmesi suretiyle, bütün kişilik bilgilerinin kataloglaştırılıp kaydedilmesinin insan haysiyetini ihlal edeceği dile getirilmektedir. ${ }^{90}$

Gerçekten de kişilik veya karakter özellikleri araştırılmadan, sadece kimliği tespite yarayan bir alanda, genetik parmak izinin çıarılması, kişinin öznelikten uzaklaştırılarak nesne hâline getirildiği anlamına gelmez. Ceza muhakemesi alanındaki adlî DNA incelemeleri kişinin kalıtımsal ve karakteristik kişisel özellikleri konu almamakta, kişinin gizli alanındaki sadece onun bilmesi gereken sır anlamındaki bilgilerine ulaşılmamaktadır. Dolayısıyla kişi en gizlisine dokunularak suçların aydınlatılmasının bir aracı hâline getirmemektedir. Burada tıpkı kan grubunun belirlenmesi sürecinde ya da resim, boy vs. gibi biyometrik verilerin tespit edilmesinde olduğu gibi, DNA dizileri yoluyla yaratılan sayısal verilerle - profiller - kimliklendirme söz konusudur. Bu da insanın sırf insan oluşunun kazandırdığı değerin tanınmaması ve sayılmaması anlamına gelmemekte, DNA analizi yapılması ona muhatap olan insanı insan olmaktan çıkarmamaktadır. Netice olarak adlî DNA incelemeleri, Alman ve Türk hukuk bakımından insan haysiyetinin dokunulmazlığı ilkesini ihlal etmemektedir.

87 Ünver, CHD, 2008, Y11: 3, Say1 7, s. 66.

88 Özbek, son erişim: 6.1.2017; Özbek, CHD, Nisan 2007, Sayı: 1, s. 59; Mahmutoğlu, s. 4, 5, son erişim: 15.01.2017.

89 BVerfG NJW 1996, s. 771, 772; Roxin/Schünemann, Strafverfahrensrecht, s. 271; Neuser, s. 85, 89; Krieglstein, s. 31, 101 vd.; Altendorfer, s. 17, 18; Joecks, StK-StPO, § 81 g pn. 4; Klumpe, s. 150 vd.; Sternberg-Lieben, NJW 1987, s. 1244, 1245; buna karşın Rademacher, StV 1989, s. 549. 


\subsubsection{Adlî DNA Analizleri ve Genel Kişilik Hakları}

DNA analizlerinin genel kişilik haklarının ihlali anlamına gelip gelmeyeceği de ayrı bir tartışma konusudur. Genel kişilik hakları, dar bir alanda kişisel yaşam alanın ve bunu oluşturan ana koşulların korunmasını güvenceye almaktadır.91 DNA analizleri kapsamında genel kişilik haklarından özellikle özel hayatın ve hayatın gizli alanının korunması,${ }^{92}$ kişinin kendi resmi üzerindeki haklar1 ${ }^{93}$ ve aynı zamanda kişisel bilgilerin geleceğini belirleme hakk1 ${ }^{94}$ (bilgiler üzerinde özerklik veya bilgilendirme özerkliği) yani kişisel verilerin korunmasını isteme hakkı ele alınmaktadır.

\section{i) Adlî DNA Analizi Yoluyla Özel Hayatı İhlal?}

Özel hayat, "kişinin kendine özgü yaşayışı, yaşama tarzı ve kendisini ilgilendiren tutum ve davranışları"; özel hayat alanı, "kişinin başkalarını içinden çıkarmaya yetkili olduğu; kişinin izni olmaksızın kimsenin giremeyeceği gizli bir alan" olarak betimlenmektedir. ${ }^{95}$ Özel hayat alanında, kişisel bir yaşam kesiti veya bir durum ya da kişiye ait bir bilgi başkalarının bilgisinden ve müdahalesinden uzak tutulmaktadır. ${ }^{96}$ $\mathrm{Bu}$ bağlamda Zafer" özel hayat alanını "başkaları ile paylaşma arzusunu taşımadığımız kişisel yaşam parçaları" olarak nitelendirmektedir. Burada belirleyici olan "diğerlerinden ayrı olma ve diğerlerine bilinmez olma durumu" olduğundan, "özel hayat hakkı, kendisi hakkındaki bilgiyi başkalarından koruma hakkı ile aynı şeydir". Özel hayat alanında olanları kişi, ailesi, yakınları ve arkadaşları gibi sıkı ilişki içinde bulunduğu sınırlı sayıdaki kişilerle paylaşmak istemektedir. ${ }^{98}$ Özel hayat alanı dışında kişinin bir de gizli hayatı bulunmaktadır.9 Bireyin "kişiliğinin nihâ̂ sığınağı" olarak nitelenen gizli hayat alanı, "normal durumlarda kişinin kimseyle paylaşmadĭ̆l, sadece kendisi için saklı tuttuğu ve hiç kimsenin bilmesini istemediğ veya maksimum çok güven duyduğu kişilere açık olay, hâl ve ilişkilerden oluşan alandır". ${ }^{100} \mathrm{Bu}$ nedenle de bu alan sınırlı sayıdaki kişiler dışında gizli tutulması

91 BVerfG 54, s. 153.

92 Klumpe, s. 129 vd.; Krieglstein, s. 102; Özbek, son erişim: 6.1.2017; Özbek, CHD, Nisan 2007, Sayı: 1, s. 60.

93 Krieglstein, s. 102.

94 Krieglstein, s. 102; Klumpe, s. 152.

95 Zafer, s. 12.

96 Zafer, s. 12.

97 Zafer, s. 12.

98 Zafer, s. 13.

99 Hayat alanını açıklamaya çalışan "ün alan terisi” hakkında ayrıntılar için Zafer, s. 13 vd.

100 Zafer, s. 13. 
gereken olay ve bilgilerden oluşur. Kişinin, "kendi kabuğuna çekilme ya da yalnı kalma hakkl" kapsamında "en önemli varlıklarından" olan, "çekirdek benlik" ve kişinin "en iç çemberi" olarak kabul edilen bu alanda "kişinin başta cinsel yaşamı olmak üzere, çıplakllğı, düşünceleri, inançları, ümitleri, korkularl, dilekleri, aile iliş̧kileri, plânları ve hisleri, iç yaşamı" gibi "sağlık, kişisel ilişkileri, mektup, telgraf, hatıra defteri gibi dış yaşamı ile ilgili" bilgiler yer almaktadır. ${ }^{101}$ Açıklanan tüm bu nedenlerle gizli hayat alanı hiçbir şekilde dokunulmaz bir alan teşkil ederken; özel hayata müdahale belirli şartlarda mümkündür. ${ }^{102}$

Almanya Anayasa m 2 I ve 1 I, Türkiye Anayasası m. 20 kapsamında koruma altına alınmış olan özel hayatın gizliliğinin korunması hakkı, daha önce de aktarıldığı üzere ${ }^{103}$ suçların aydınlatılmasında yatan kamu yararı gerekçesi ve anayasal koşullara uyma şartıyla sınırlandırılabilecektir. Öğreti ${ }^{104}$ ve uygulamada ${ }^{105}$ adlî DNA incelemelerinin hayatın gizli alanına tecavüz teşkil etmediği, ancak özel hayata ilişkin bir müdahalede bulunulduğu; bununla birlikte bu saldırının anayasal sınırlamalara uymak şartıyla anayasaya uygun oldukları kabul edilmektedir.

Gerçekten de ceza muhakemesinde adlî DNA analizi, DNA'nın kodlanmamış alanında yapıldığından, bireyin sir olarak tutmak isteyeceği gizli bilgilerine erişilmemektedir. Adlî DNA analizleri elde ettiği sayısal dizilerle sahibine özgür bir sayılar dizini ortaya çıkarmakta, bu dizi de sadece kimliklendirmeye hizmet etmektedir. Burada kişinin gizli alanına girecek, o suçu işleyip işlememe potansiyelini belirleyecek herhangi bir kişilik özelliği, gen defektleri, rrksal ya da fiziksel özellikleri, vücut yapısı vs. gibi özellikleri tespit edilmemekte, gizli bilgilere ulaşılmamaktadır. Dolayısıyla hayatın gizli alanına yönelik bir müdahale yoktur. Bununla birlikte kişiye özgü olan DNA profilinin elde edilmiş olması özel hayata bir saldırı teşkil ettiği gibi, profil neticesinde elde edilecek tüm doğrudan ya da dolaylı bilgiler de, kişinin herkesin bilmesini istemeyeceği özel bilgiler mahiyetinde olabilir. Olay yerinde DNA materyalinin bulunduğunun belirlenmesi ile kişinin bir şekilde orada bulunduğunun ve orada neler yaptığının ortaya çıkarılması dahi özel hayata ilişkin bir durumdur. $\mathrm{Bu}$ nedenle her hâlükârda özel hayata bir saldırıda bulunulmaktadır.

101 Zafer, s. 13.

102 Zafer, s. 13.

103 Bkz. 64-71 arasındaki dipnotları.

104 Krieglstein, s. 102; Benfer, StV 1999, s. 403; Krehl/Kolz, StV 2004, s. 455; Sternberg-Lieben, NJW 1987, s. 1245; Özbek, son erişim: 6.1.2017; Özbek, CHD, Nisan 2007, Say1: 1, s. 62.

105 BVerfG NJW 1996, s. 771, 772. 
Ancak efektif bir ceza yargılaması yapılması ve suçların aydınlatılmasında yatan kamusal yarar orantılı ve anayasal koşullara uygun bir müdahaleye katlanmayı da beraberinde getirmektedir. Müdahalenin orantılı olması bakımından gerek Türk gerekse Alman mevzuatında DNA profilinin tespitinden sonra, genleri içeren gen materyallerinin yok edilmesi zorunluluğu öngörülmüştür. Buna ek olarak özellikle Almanya'da DNA analizi ile elde edilen verilerin aktarılacağı sınırlı sayıda kişi ve kurumlar hakkında yasal mevzuatta detaylı düzenlemeler yapılmaktadır. Tüm bu gerekçelerle adlî DNA analizine ilişkin olarak mevcut ceza muhakemesi normlarıyla özel hayatı sınırlamaya yönelik düzenlemelerin anayasaya uygun olduğu ifade edilebilir.

\section{ii) Adlî DNA Analizi Yoluyla Resim Üzerindeki Hakkı İhlal?}

Moleküler genetik incelemeler sonucunda normalde insan gözüyle görülemeyen DNA dizileri görülür hâle getirilmektedir. Elde edilen bu görüntü, bireye özgü olduğundan gerçekten de kimliklendirme yapılabilecek moleküler biyolojik vesikalık bir resim olarak kabul edilmektedir. ${ }^{106}$ Gerçekten de "kişinin DNA'sına birebir karşıllı gelen şifrelenmiş, numara dizileri" ${ }^{107}$ olarak kabul edilen DNA profilin "fotoğraf benzeri bir tablo" 108 niteliğindedir. Bu da Alman Anayasası ile korunan genel kişilik haklarından resim üzerindeki hak; Türk hukuku bakımından ise hem genel kişilik hakları (m. 17 I) hem de kişisel verilerin korunması (m. 20 II) kapsamında önem taşımaktadır.

"Resim üzerindeki hak" kişiye, kendisi hakkında ifşada bulunma üzerinde tasarruf hakk1 vermektedir. ${ }^{109}$ Alman Federal Anayasa Mahkemesi, kural olarak herkesin, kendi hayatının ya da hayatından bir kesitin bir başkası tarafından kamuya açılmasına izin verip vermeme ya da ne boyutta açacağına izin verme hakkına, bizzat ve sadece kendisinin sahip olduğunu ifade etmektedir. ${ }^{110}$ Adlî DNA incelemeleri yoluyla elde edilen genetik parmak izlerinin, resim üzerindeki hakka yönelik bir müdahale teşkil ettiği, ancak mevcut durumun anayasaya uygun olduğu kabul edilmektedir. ${ }^{111}$ Türk hukuku bakımından resim üzerindeki hak, kişisel verilerin korunması bakımından önem kazandığından, bu husus ilgili kısımda tartışılacaktır.

106 Krieglstein, s. 104.

107 Öztürk, s. 5.

108 Yenisey/Nuhoğlu, CMH, s. 654.

109 BverfG 34, s. 245.

110 BVerfG 35, s. 220.

111 Krieglstein, s. 104. 


\subsubsection{Adlî DNA Analizi ve Kişisel Bilgilerin Geleceğini Belirleme Hakkı} (Bilgiler Üzerinde Özerklik veya Bilgilendirme Özerkliği ya da Kişisel Verilerin Korunmasını İsteme Hakkı)

Moleküler genetik incelemeler yoluyla genetik parmak izinin belirlenmesi, DNA profilinin (kimlik şablonunun) işlenmesi ile kaydedilmesi ve en nihayetinde gerektiğinde genetik parmak izi bilgisinin diğer ceza yargılamalarında tekrar kullanılmak üzere ilgili mercie aktarılması, özellikle kişisel bilgilerin geleceğini belirleme hakkı (ya da bilgiler/veriler üzerinde özerklik veya bilgilendirme özerkliği ya da Türk hukukunda yaygın ifadesiyle kişisel verilerin korunmasını isteme hakk1 das Recht auf informationelle Selbstbestimmung) kapsamında yoğun tartışmalara konu olmuştur. Türkiye' de konu CMK kapsamında moleküler genetik araştırmalarla alakalı olarak ele alınmış, henüz DNA profillerinin kaydedilip ileride tekrar kullanılmalarına ilişkin bir yasal düzenleme bulunmadığından konu özellikle " $D N A$ Verileri ve Türkiye Milli DNA Veri Bankası Kanunu Tasarısı" kapsamında kişisel verilerin korunması çerçevesinde önem kazanmıştır. Aşağıda bu husustaki Alman ve Türk hukukundaki tartışmalar aktarılmaya çalışılacaktır.

\section{i) Bireyin Kişisel Bilgilerinin Geleceğini Belirleme Hakkı}

Kişisel bilgilerin geleceğini belirleme hakkı, genel kişilik haklarından biri olup,Alman Anayasası m. 2 I ve bununla bağlantılı insan haysiyetinin dokunulmazlığını öngören m. 1 I'den çıkarılmakta; bu bağlamda kişiliğin özgürce geliştirilmesi hakkından, kişisel verilerin kullanılması ve bunların ne ölçüde nasıl ifşa edileceğinin kişinin bizzat kendinin belirleme hakkının doğduğu kabul edilmektedir. $^{112}$

İnsan daima iletişim hâlinde olan bir canlıdır ve iletişim konusunun içeriğine, şekline, iletişimde bulunulacak diğer tarafın kim olacağına vs. bizzat kendisi karar vermektedir. ${ }^{113}$ Veriler, iletişim sürecinin yapı taşı olduğundan, iletişimin tarafları olan kişilerin, veriler üzerinde tasarruf hakkına sahip olmaları zorunludur. ${ }^{114} \mathrm{Bu}$ nedenle de bilgilendirme özerkliği ya da kişisel verilerin geleceğini belirleme hakkının koruma alanı sadece iletişimin tarafı, içeriği ve şeklini belirleme yetkisini değil, aynı zamanda belirli alanların kısmen ya da tamamen

112 BVerfG 65, s. 43; Weichert, s. 11; Klumpe, s. 152.

113 Weichert, s. 11.

114 Weichert, s. 12. 
bilgilendirme dışında bırakılmasını belirleme yetkisini de kapsamaktadır. ${ }^{115}$ Şu hâlde bireyin toplum içerisindeki rolünü müstakil, serbest ve kendi sorumluluğunu kendisinin üstleneceği şekilde belirleyebileceği olanaklara da sahip olabilmesi gerekmektedir. Kişisel veri ya da bilgilerin belirlenmesi veya aktarılması bu hak kapsamındadır. Bu özgürlük kişinin kendini ifade yöntemini, iletişimin ya da bilgilendirmenin yeri ve zamanını ve iletişimde bulunulacakları belirleme özgürlüklerini kapsamadığından bu hakka kendini tasvir özgürlüğ̈̈ - die Freiheit zur Selbstdarstellung ${ }^{116}$ de denilmektedir.

Verilerin Korunmasina Dair Federal Kanun (Bundesdatenschutzgesetzes) kapsamında anılan kişisel veriler, bilgilendirme özerkliği hakkının koruması altındadır. ${ }^{117} \mathrm{Bu}$ bağlamda DNA analizi neticesinde elde edilen genetik parmak izinin bu Kanun kapsamındaki kişisel verilerden olup olmadığının tespiti gerekmektedir.

Verilerin Korunmasına Dair Federal Kanun m. 3 I’e göre "kişisel veriler", belirli ya da belirlenebilen bir gerçek kişinin (ilgilinin), kişisel ya da olgusal durumuna ilişkin müstakil bilgilerdir. ${ }^{118}$ Müstakil bilgiler (Einzelangaben) kavramından, belirli - müstakil - gerçek bir kişiye ait olan ya da onunla ilişkilendirmeye uygun olan bilgiler anlaşılmaktadır. ${ }^{119}$ Bunun için amaçsal, aracı ya da saklayıcı olmaya yönelik bir unsurun mevcudiyeti şarttır. ${ }^{120}$ İşte bu nedenle izler, örneğin kan izleri, parmak izleri ya da lekeler bilgi olarak kabul edilmezler. ${ }^{121}$ Bunlar ancak ölçmek, işaretlemek, incelmek ya da tasvir etmek yoluyla iletmek ya da saklamak amacıyla bilgi üretilmesi için bir çıkış noktası teşkil edebilirler. ${ }^{122}$

Müstakil bilgiler ayrıca bir kişinin kişisel ya da olgusal durumunu konu almalıdır. İlgilinin bizzat şahsına ait, kimliklendirilmesi ve karakteristik özellikleri hakkındaki veriler "kişisel durumlar" olarak kabul edilir. ${ }^{123}$ Örneğin isim, meslek, sağlık durumu, özellikler, resimler, parmak izi, röntgen filmi vs. kişisel duruma ilişkin müstakil

115 Weichert, s. 12.

116 Weichert, s. 11.

117 BVerfG 65, s. 42; Klumpe, s. 154.

118 Gola/Schomerus/Klug, BDSG, § 3; Simitis, BDSG, § 3.

119 Gola/Schomerus/Klug, BDSG, § 3 pn. 3.

120 Simitis, BDSG/Dammann, $\S 3$ pn. 5.

121 Simitis, BDSG/Dammann, $\S 3$ pn. 5.

122 Simitis, BDSG/Dammann, $\S 3$ pn. 5.

123 Gola/Schomerus/Klug, BDSG, § 3 pn. 4, 5. 
bilgilerdir. ${ }^{124}$ "Olgusal durumlar", ilgiliyle ilişkilendirilebilen bir olgu hakkındaki bilgiler, mesela ilgilinin ikametgâhı, üçüncü kişiyle yapılan bir telefon görüşmesi, yargilama bilgileri vs., yoluyla ortaya konulan durumlardır. ${ }^{125}$

En nihayetinde kişinin belirli ya da belirlenebilir olması gerekmektedir. Eğer bilgilerden kişiye ya da sadece bir kişiye ulaşıllyorsa kişi belirli demektir. $\mathrm{Bu}$ bağlamda kişinin ne şekilde kimliğinin belirlendiğinin vs. önemi yoktur. ${ }^{126}$

Tüm bu açıklamalardan sonra DNA analizi yoluyla elde edilen DNA profilinin, kimliklendirme ve sadece belirli bir kişinin, kişisel durumunun tespit edilebilmesi imkânı yaratan, kişisel bir bilgi içermesi sebebiyle, Verilerin Korunmasına Dair Federal Kanun kapsamında anılan bir kişisel veri teşkil ettiğinden şüphe yoktur. ${ }^{127}$

\section{ii) DNA Analizleri Yoluyla Bilgilendirme Özerkliği Hakkını İhlal?}

Anıldığı üzere bilgilendirme özerkliği hakkı bireyi, genetik bilgilerinin işlenmesinden koruduğu gibi bu bilgilerin aktarılması, kaydedilmesi gibi fiillerden de korumaktadır. Dolayısıyla bireyin bizzat kendisinin kişisel verilerini kullanması veya kullanmaması ya da ifşa etmesi yetkisinde herhangi bir sınırlamaya gidilmesi, kişinin kişisel verilerinin geleceğini belirleme hakkına tecavüz teşkil edecektir. Bu bağlamda DNA analizi sonrasında yaratılan DNA profillerinin oluşturulması, ayrıca kimlik tespiti amacıyla kullanılmak üzere kaydedilmesi, ihtiyaç duyulduğunda karşılaştırmaya tabi tutulması vs. kişilerin DNA profillerinin ne zaman, hangi amaçla, kime aktarılacağı konusunda bizzat kendisinin karar verememesini beraberinde getirmektedir. Bu nedenle de DNA profillerinin yaratılması, kullanılması, işlenmesi, kaydedilmesi, tespit edilmesi vs. anayasal güvence altında olan bilgilendirme özerkliği hakkına saldırı teşkil etmektedir. ${ }^{128}$

Ancak bilgilendirme özerkliği hakkı da tüm diğer temel haklar gibi, anayasal sınırlamalara uyulmak koşuluyla sınırlandırılabilecektir ki Alman Federal Anayasa Mahkemesi $^{129}$, AlmCMK m. 81g hükmünün tüm koşulları yerine getirdiğine

124 Gola/Schomerus/Klug, BDSG, § 3 pn. 4, 5.

$125 \mathrm{Gola} / \mathrm{Schomerus} / \mathrm{Klug}, \mathrm{BDSG}, \S 3$ pn. 6.

126 Simitis, BDSG/Dammann, $\S 3$ pn. 20.

127 Krieglstein, s. 103; Klumpe, s. 154; Stumper, s. 82.

128 LG Freibug, NStZ 2000, s. 162; LG Gera, NStZ 2000, s. 163; BVerfG StV 2001, s. 380; Neuser, s. 91, 92 , 96; Foldenauer, s. 133; Klumpe, s. 157; Burr, s. 117; Krieglstein, s. 103, 104; Benfer, StV 1999, s. 402; Rademacher, StV 1989, s. 550.

129 BVerfG 103, s. 33; BVerfG NJW 2001, s. 879. 
hükmetmiş, hükmü hukuka ve anayasaya uygun bulmuştur. Mahkemeye göre, ileride vuku bulacak ağır suçların aydınlatılması, ceza yargılama sisteminin işlevselliğine hizmet edecektir ve bu da suçların aydınlatılmasındaki kamusal yararı oluşturmaktadır. ${ }^{130}$ Belirlilik ilkesine de uygun olan hükümde, kişilik haklarının çekirdeğine de dokunulmamaktadır, zirâ incelemeler DNA'nın kodlanmamış alanında yapıldığından, kalıtımsal ya da karakteristik özellikler ya da hastalıklar vs. araştırılmamaktadır. ${ }^{131}$ Ayrıca her somut olay hükümde anılan koşullar bakımından müstakil olarak inceleme konusu da yapilacaktır. ${ }^{132}$

\section{iii) Adlî DNA Analizi ve Kişisel Verilerin Korunmasını İsteme Hakkı}

Kişisel bilgilerin geleceğini belirleme hakk1, "bireyin kendi geleceğini belirleme hakkı" gibi, insan haysiyetinin korunması ve kişinin maddî ve manevî varlığını geliştirme hakkından doğmaktadır. Şu hâlde kişisel bilgiler veya verilerin geleceğini belirleme hakkının da, kişinin maddî ve manevî varlığını geliştirme hakkı (Anayasa m. 17 I) ve insan öz saygınlığının (insan onuru) korunması ilkesi (Anayasa m. 17 III) kapsamında koruma altında olduğu söylenebilir. Bunun yanında Türk hukukunda bu hak daha çok kişisel verilerin korunmasını isteme hakkı kapsamında değerlendirilmektedir.

Kişisel verilerin korunması hakkı T.C. Anayasası m. 20 III kapsamında düzenlenerek, özel olarak anayasal korumaya alınmıştır. Anayasa Mahkemesine ${ }^{133}$ göre Anayasa'nın “ ̈̈zel hayatın gizliliği” başlıklı 20. maddesine 3. fikra olarak, 2010 yılında eklenen kişisel verilerin korunması hakkı "kişinin insan onurunun korunmasının ve kişiliğini serbestçe geliştirebilmesi hakkının özel bir biçimi olarak, bireyin hak ve özgürlüklerini kişisel verilerin işlenmesi sırasında korumayı

130 BVerfG 103, s. 21, 22.

131 BVerfG 103, s. 31, 32.

132 BVerfG NJW 2001, s. 879; krş. LG Zweibrücken, StV 2000, s. 304.

133 Anayasa Mahkemesi E: 2014/122, K: 2015/123, T: 30.12.2015, RG Tarih-Sayı: 01.03.2016 - 29640, iç: http://kararlaryeni.anayasa.gov.tr/Karar/Content/004ab030-da $02-462$ b- $9990-$ 84cad78525c9?higllightText=kişisel\%20veri\&excludeGerekce=False\&wordsOnly=False, son erişim: 28.11.2016; ayrıca Anayasa Mahkemesi E: 2014/180, K: 2015/30, T: 19.3.2015, RG Tarih-Say1: 3.4.201529315, iç: http://kararlaryeni.anayasa.gov.tr/Karar/Content/eb0ec514-e01c-47ba-86bedadfd0c0c2b3?higllightText $=$ dna $\% 20$ analizi\&excludeGerekce $=$ False \&wordsOnly $=$ False, son erişim: 29.11.2016. 
amaçlamaktadır."134 Hükme göre "Herkes, kendisiyle ilgili kişisel verilerin korunmasını isteme hakkına sahiptir. Bu hak; kişinin kendisiyle ilgili kişisel veriler hakkında bilgilendirilme, bu verilere erişme, bunların düzeltilmesini veya silinmesini talep etme ve amaçları doğrultusunda kullanılıp kullanılmadı̆̆ını öğrenmeyi de kapsar. Kişisel veriler, ancak kanunda öngörülen hâllerde veya kişinin açık rızasıyla islenebilir. Kişisel verilerin korunmasına ilişkin esas ve usuller kanunla düzenlenir." $\mathrm{Bu}$ şekliyle kişisel verilerin korunması hakkı, Alman hukukundaki bilgilendirme özerkliği veya kişisel bilgilerin geleceğini belirleme hakkı gibi, kökleri insan haysiyetinin dokunulmazlığı ve maddî ve manevî varlığı geliştirme hakkına dayanan bir hak niteliğini haiz olmakta; sadece Anayasa m. 17 aracılığ́ ile değil aynı zamanda m. 20 III aracılığı ile de korunmaktadır.

DNA profillerinin kaydedilip ileride tekrar kullanılmaları ile ortaya çıkan temel haklara saldırı Türk hukukunda ${ }^{135}$ genellikle özel hayatın ve kişisel verilerin korunmasını isteme hakkı kapsamında öne çıkmaktadır. 2007 yılındaki " $D N A$ Verileri ve Türkiye Milli DNA Veri Bankası Kanunu Tasarısı" gerekçesi de bu hususa işaret etmektedir: "DNA verileri, ait olduğu kişiyle ilgili kalıtsal pek çok bilgiyi de içermektedir. Bu bakımdan Anayasanın 20. maddesi ile Ülkemizin de taraf olduğu, Avrupa İnsan Haklar Sözleşmesinin 8. maddesinde koruma altına alınan 'özel hayatın gizliliği' ile ilgili bir husustur. Hür ve demokratik bir toplumda kişi dokunulmazlığı, hem devletin hem de kişi ve organizasyonların kişinin özel hayatına girmesinin önünde bir engeldir. Günümüz teknolojisiyle tamamen olmasa da bilim ve teknikteki gelişmelere bağll olarak, DNA verilerinden örneğin; kişinin saç rengi, göz rengi, yapısı, hastalıkları, etnik kökeni, diğer özellikleri, kardeşi, çocukları veya anne babasının tespit edilmesinin mümkün olabildiği düşünüldüğünde, verilerin elde edilmesi, saklanması ve kullanılmasının sıkı yasal koşullara bağlanması zorunluluğunu ve ihtiyacını ortaya çıkmaktadır. DNA verilerinin kullanım amacı ve kişisel verilerin korunması, uluslararası sözleşmelerde ve Avrupa Birliği

134 Anayasa Mahkemesi E: 2014/122, K: 2015/123, T: 30.12.2015, RG Tarih-Say1: 01.03.2016 - 29640, iç: http://kararlaryeni.anayasa.gov.tr/Karar/Content/004ab030-da $02-462$ b-999084cad78525c9?higllightText=kişisel\%20veri\&excludeGerekce=False\&wordsOnly=False, son erişim: 28.11.2016; Ayrica Anayasa Mahkemesi E: 2014/180, K: 2015/30, T: 19.3.2015, RG Tarih-Say1: 3.4.201529315, iç: http://kararlaryeni.anayasa.gov.tr/Karar/Content/eb0ec514-e01c-47ba-86bedadfd0c0c2b3?higllightText $=$ dna $\% 20$ analizi\&excludeGerekce $=$ False \&wordsOnly $=$ False,$\quad$ son $\quad$ erişim: 29.11.2016.

135 Yenisey/Nuhoğlu, CMH, s. 654; Özbek, son erişim: 6.1.2017; Batur, TBBD 2016 (126), s. 88; Aksoy İpekcioğlu, iç: Centel'e Armağan, s. 1162. 
müktesebatında da yer almıştır [...]"136

Anayasa Mahkemesi ${ }^{137}$ uluslararası sözleşmeler kapsamındaki kişisel veri tanımlarını şu şekilde aktarmaktadır: "Türkiye’nin imzaladığı ancak uygulama kanununun yürürlüğe konmaması nedeniyle henüz taraf olmadığgl ${ }^{138} 1981$ tarihli ve 108 sayılı Kişisel Verilerin Otomatik Işsleme Tabi Tutulması Karşısında Kişilerin Korunmasına Dair Avrupa Konseyi Sözleşmesi'nin 2. maddesine” göre kişisel veri, "kimliği belirli veya belirlenebilecek verinin öznesi olan gerçek kişiyle ilgili tüm bilgiler” olup, Sözleşme'nin “özellikli veri kategorileri” başlıkl1 6. maddesine göre de "iç hukukta uygun güvenceler sağlanmadıkça, ırk menşeini, politik düşünceleri, dinî veya diğer inançları ortaya koyan kişisel nitelikteki verilerle săglık veya cinsel yaşamla ilgili kişisel nitelikteki veriler ve ceza mahkûmiyetleri, otomatik bilgi işlemine tâbi tutulamazlar" ifadesi söz konusu verilerin kişisel veri kapsamında olduğu belirtilmektedir. Anayasa Mahkemesi karşılaştırmalı tanımlamaya devam ederek şu saptamalarda bulunmuştur: “Ekonomik Kalkınma ve İşbirliği Örgütü’nün (OECD) yayınladı̆̆ Kişisel Verilerin Korunması Rehber Illkeleri'nde 'kişisel veri', 'belirli veya belirlenebilir bir gerçek kişiye ilişkin tüm bilgiler' şeklinde tanımlanmaktadır. Avrupa Birliği'nin 95/46/EC sayılı Veri Koruma Direktifi'nin 2. maddesinde de 'kişisel veri', 'belirli ya da kimliği belirlenebilir gerçek kişi ile ilişkilendirilebilen her türlü bilgi' şeklinde tanımlandıktan sonra 'bir kişinin doğrudan veya dolaylı olarak tanımlanabilmesine imkân sağlayan kişinin kimlik numarası, fiziksel, psikolojik, duygusal, ekonomik ve kültürel kimliği veya sosyal kimliğin'nin bu kapsamda değerlendirildiği ifade edilmektedir. 'Kişisel veri' kavramı tarafi olduğumuz Avrupa Insan Hakları Sözleşmesi’nde (AIHS) açık bir şekilde

136 http:/www.ttb.org.tr/index.php/Haberler/dna-verileri-ve-tye-milli-dna-veri-bankasnunu-tasar-471.html, son erişim: 3.12.2016.

137 Anayasa Mahkemesi E: 2015/32, K: 2015/102, T: 12.11.2015, RG: 02.12.2015 - 29550, bu kararda 26.9.2004 tarihli ve 5237 sayılı Türk Ceza Kanunu'nun, 21.2.2014 tarihli ve 6526 sayılı Kanun'un 4. maddesiyle değişik 136. maddesinin (1) numaralı fikrasının ["Madde 136- (1) Kişisel verileri, hukuka aykırı olarak bir başkasına veren, yayan veya ele geçiren kişi, iki yıldan dört yıla kadar hapis cezası ile cezalandırılır.'] Anayasa'nın 38. maddesine aykırılı̆̆ı iddiasını incelemiştir.

138 Bugüne kadar Avrupa Konseyi üyesi bütün ülkeler ve Avrupa Konseyi dışından Uruguay olmak üzere toplam 47 ülke Sözleşmeye taraf olmuş, 46 ülke ise Sözleşmeyi onaylamıştır. Türkiye Sözleşme'yi imzalamış olmasına rağmen, onay işlemlerini tamamlamayıp yürürlüğe koymayan tek ülke konumunda idi. "Kişisel Verilerin Otomatik İşleme Tabi Tutulması Karşısında Bireylerin Korunması Sözleşmesinin Onaylanmasının Uygun Bulunduğuna Dair Kanun Tasarısı” 2014 yılında hazırlanmış ancak komisyon raporları verilmediğinden hükümsüz kalmıştı. Bkz. https://www.tbmm.gov.tr/develop/owa/tasari_teklif_ gd.onerge_bilgileri?kanunlar_sira_no=162475, https://www.tbmm.gov.tr/sirasayi/donem24/yi101/ss 700 . pdf, http://www2.tbmm.gov.tr/d24/1/1-0966.pdf, son erişim: 22.11.2016. Ancak en nihayetinde 30.01.2016 tarihli 6669 sayılı Kanun ile Sözleşme'nin onaylanması uygun görülmüştür. Yayınlanan Resmi Gazete http://www.resmigazete.gov.tr/eskiler/2016/03/20160317-2.pdf, son erişim: 10.01.2017. 
düzenlenmemekle birlikte, Sözleşme’nin uygulanmasına ilişkin Avrupa İnsan Haklarl Mahkemesi (AIHH) kararlarında Kişisel Verilerin Otomatik İşleme Tabi Tutulması Karşısında Bireylerin Korunmasına Dair Sözleşme’ye atıfta bulunulmakta ve bu verilerin özel yaşamın gizliliğinin bir parçası olduğu kabul edilmektedir. AIHHM kararlarında kişilere ait 'görüntü', 'fotoğraf', 'parmak izi', 'DNA profili', 'hücre örnekleri', 'ev adresi've 'yaş, doğum tarihi ve fiziksel özellikler', 'kişisel veri' kapsamında değerlendirilmektedir (Peck/Birleşik Krallık, B.No: 44647/98, 28.01.2003; Sciacca/İtalya, B.No:50774/99, 11.01.2005; S. ve Marper/Birleşik Krallı, (Büyük Daire), B.No: 30562/04, 30566/04, 04.12.2008; Alkaya/Türkiye, B. No:42811/06, 09.10.2012; K.U./Finlandiya, B.No:2872/02, 02.12.2008)."

En nihayetinde Anaysa Mahkemesi kişisel veri kavramını, "belirli veya kimliği belirlenebilir olmak şartıyla, bir kişiye ilişkin bütün bilgiler"139 olarak tanımlamaktadır. "Bu bă̆lamda adl, soyadl, doğum tarihi ve doğum yeri gibi bireyin sadece kimliğini ortaya koyan bilgiler değil; telefon numarası, motorlu taşıt plakası, sosyal güvenlik numarası, pasaport numarası, özgeçmiş, resim, görüntü ve ses kayıtları, parmak izleri, genetik bilgiler, IP adresi, e-posta adresi, hobiler, tercihler, etkileşimde bulunulan kişiler, grup üyelikleri, aile bilgileri gibi kişiyi doğrudan veya dolaylı olarak belirlenebilir kılan tüm veriler kişisel veri kapsamındadır." 140

Anayasa Mahkemesince yapılan tanımın Kişisel Verilerin Korunması Kanunu ${ }^{141}$ m. 3 I d içerisinde de öngörüldüğü görülmektedir: "Kişisel veri: Kimliği belirli veya belirlenebilir gerçek kişiye ilişkin her türlü bilgi”yi ifade eder. Kişisel Verilerin Korunması Kanunu m. 6 I, kişilerin ırkl, etnik kökeni, siyasi düşüncesi, felsefi inancı, dini, mezhebi veya diğer inançları, kllık ve klyafeti, dernek, vaklf ya da sendika üyeliği, săglı̆̆l, cinsel hayatı, ceza mahkûmiyeti ve güvenlik tedbirleriyle ilgili verileri ile biyometrik ve genetik verileri özel nitelikli kişisel veridir.

Biyometri, "bir karakteristik özelliği veya bununla ilgili işlemi tanımlamaya

139 Anayasa Mahkemesi E: 2014/180, K: 2015/30, T: 19.3.2015, RG Tarih-Sayı: 3.4.2015-29315, iç: http:// kararlaryeni.anayasa.gov.tr/Karar/Content/eb 0 ec 514 - e 01 c - 47 ba - 86 be dadfd0c0c2b3?higllightText $=\mathrm{dna} \% 20$ analizi\&excludeGerekce $=$ False \&wordsOnly $=$ False, son erişim: 29.11.2016.

140 Anayasa Mahkemesi, E: 2014/180, K: 2015/30, T: 19.3.2015, RG Tarih-Say1: 3.4.2015-29315, iç: http:// kararlaryeni.anayasa.gov.tr/Karar/Content/eb 0 e c 514 - e 01 c- 47 ba- 86 be dadfd0c0c2b3?higllightText $=$ dna $\% 20$ analizi\&excludeGerekce $=$ False \&wordsOnly $=$ False, $\quad$ son erişim: 29.11.2016.

1416698 sayılı Kanun, Kabul Tarihi: 24/3/2016, Resmi Gazete: 29677, 7/4/2016, iç: http://www.resmigazete. gov.tr/eskiler/2016/04/20160407-8.pdf, son erişim: 22.11.2016. 
yarayan bir terim"142; biyometrik veri, "biyolojik, fizyolojik ve kişisel özellikler ya da tekrar edilen hareketler gibi bir kişiye özgü olan ve ölçümü yapılabilen, ölçümün uygulanmasinda da belirli bir ihtimal derecesi sunan özellikler ve/veya eylemlerdir. Bu veriler belirli bir kişi hakkında bilgi ihtiva etmeleri yanında, inceleme konusu bir veri ile kişi arasındaki irtibatı kurmaya da yardımcı olmaktadırlar."143. Biyometrik veriler, parmak izi, avuç izi, yüz görüntüsü ve iris ile DNA'dır. ${ }^{144}$ "İnsan doku örnekleri biyometrik verinin elde edildiği kaynaklar olmakla beraber tek başlarına biyometrik veri olarak kabul edilemezler. Örneğin, parmak izi bir biyometrik veri iken parmak bir biyometrik veri değildir." ${ }^{145}$ DNA'dan adlî DNA analizi yapılarak DNA kimlik şablonu yani DNA profili elde edilmektedir. DNA profilleri, "kişinin DNA'sına birebir karşıllı gelen şifrelenmiş, numara dizileridir" ${ }^{146}$. Bu numara dizileri her kişide farklı farklı olduklarından "kişinin kimlik belirteci" ${ }^{147}$ niteliğindedirler.

Şu hâlde genetik parmak izi mahiyetinde olan DNA profillerinin (kimlik şablonları) kişiyi belirli veya belirlenebilir kılan biyometrik bir veri olarak, kişisel veri mahiyetinde olduklarından şüphe yoktur. ${ }^{148}$ Ayrıca bunlar Kişisel Verilerin Korunması Kanunu kapsamında özel nitelikli kişisel veridir. Tüm bunlara ek olarak mevcut CMK m. 80 I de DNA profillerini kişisel veri olarak görmektedir: "kişi 75, 76 ve 78 inci madde hükümlerine göre alınan örnekler üzerinde yapılan inceleme sonuçları, kişisel veri niteliğinde olup, başka bir amaçla kullanılamaz; dosya içeriğini öğrenme yetkisine sahip bulunan kişiler tarafindan bir başkasına verilemez." Şu hâlde Türk hukukunda DNA profilleri sadece Anayasa m. 17 değil, kişisel veri olarak Anayasanın 20. maddesinin de koruması altındadır. Bunun yanında Kişisel Verilerin Korunması Kanunu'nun korumalarından da yararlanmaktadır.

Ancak birçok temel hakta olduğu gibi kişisel verilerin korunması hakkı da kamu düzeninin korunması, efektif ceza yargılaması ve suçların aydınlatılmasında yatan kamu yararı gibi nedenlerle Anayasa'nın 13. maddesi koşullarına uymak şartıyla sınırlandırılabilecektir: "Türkiye Cumhuriyeti’nin imzaladĭ̆ ancak uygulama kanununun yürürlüğe konamaması nedeniyle taraf olmadı̆̆ 1981 tarihli ve 108

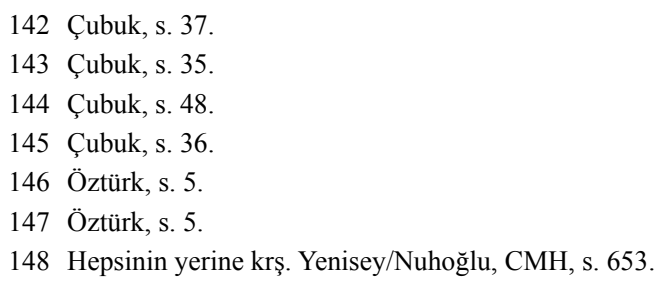


sayılı Kişisel Verilerin Otomatik İşleme Tabi Tutulması Karşısında Kişilerin Korunmasına Dair Avrupa Konseyi Sözleşmesi ’nin 9. maddesinde de devlet güvenliği, kamu güvenliği, devletin ekonomik menfaatlerinin korunmast ve suçlarla mücadele edilmesi, ilgilinin veya üçüncü kişilerin hak ve özgürlüklerinin korunması ile verilerin istatistikî veya bilimsel amaçlarla kullanılması durumlarında kişisel verilerin korunmasına sınırlamalar getirilebileceği öngörülmüştür. "149

Bu bağlamda, DNA profillerinin kişisel veri niteliğinde olup, başka bir amaçla kullanılamayacă̆ını ve aynı zamanda dosya içeriğini öğrenme yetkisine sahip bulunan kişiler tarafindan bir başkasına verilemeyeceğini öngören CMK m. 80 I, kişisel verilerin korunmasını isteme hakkı bakımından anayasaya uygun bir hüküm mahiyetindedir. Bununla birlikte de lege ferenda $\mathrm{CMK}$ içerisinde bir düzenlemeye gidilerek, gelecekteki yargılamalarda kullanılmak üzere adlî DNA analizi yapılmasına ve DNA profillerinin kaydı ve tekrar kullanımına ilişkin getirilecek hükümlerin de anayasan sınırlamaları göz önünde bulundurarak normlaşması gerekecek, aksi takdirde temel haklara yönelik ağır bir saldırı ile karşı karşıya kalınacaktır.

\section{Karşılaştırmalı Hukukta ve TürkCMK Kapsamındaki Adlî DNA Analizine İlişkin Hükümler}

TürkCMK'dan farklı olarak AlmCMK içerisinde doğrudan moleküler genetik incelemeye ilişkin 4 hüküm bulunmaktadır. Bunların haricinde tıpkı TürkCMK'da olduğu gibi beden muayenesine yönelik hükümlere de yer verilmiştir. AlmCMK m. 81a şüpheli/sanığın; 81c diğer kişilerin beden muayenesine; m. 81e moleküler genetik incelemeye, m. $81 \mathrm{f}$ moleküler genetik inceleme usulüne ilişkindir. TürkCMK m. 75'e ve AlmCMK m. 81e'ye denk gelebilecek hüküm, Avusturya'da AvCMK m. 124'te, İsviçre'de İsvCMK m. 255 içerisinde öngörülmüştür.

Türk ceza muhakemesi hukukunda yer almayan gelecekteki yargılamalarda kullanmak üzere DNA profili kaydına ilişkin hükümler Almanya'da AlmCMK m. 81g, İsviçre'de İsvCMK m. 256'da, Avusturya'da ise Güvenlik Güçleri Kanunu m. 67'de öngörülmüştür.

Yine Türk ceza muhakemesi hukukunda yer almayan kitlesel DNA analizlerine ilişkin hükümler AlmCMK m. 81h ve İsvCMK m. 257'de yer almaktadır.

149 Anayasa Mahkemesi E: 2014/180, K: 2015/30, T: 19.3.2015, RG Tarih-Sayı: 3.4.2015-29315, iç: http:// kararlaryeni.anayasa.gov.tr/Karar/Content/eb0ec $514-$ e 01 c - 47 ba - 86 be dadfd0c0c2b3?higllightText $=$ dna $\% 20$ analizi\&excludeGerekce $=$ False \&wordsOnly $=$ False, son erişim: 29.11.2016. 
TürkCMK içerisinde yer almayan AlmCMK m. 81g ve h dişındaki hükümlerin iki ülke bakımından büyük farklılıklar göstermediği görülmektedir. Aşağıda öncelikle de lege lata bu benzerlik ve farklılıklara genel olarak değinilerek, de lege ferenda önerilerde bulunulmaya çalışılacaktır.

\subsection{Adlî DNA Analizlerine İlişkin Ortak Hükümler ve de lege ferenda Öneriler}

\subsubsection{Türk ve Alman Ceza Muhakemesinde Ortak Hükümler}

TürkCMK m. 75'e denk gelen, AlmCMK m. 81a şüpheli/sanığın beden muayenesi ve bedene yönelik müdahalelere ilişkindir. Hükümde şüpheli ya da sanık üzerinde iç beden muayenesinin yapılması ya da vücuttan kan örneği alınması gibi bedene yönelik diğer müdahalelere ilişkin koşullar öngörülmektedir. Diğer kişilerin beden muayenesi ve vücuttan örnek alınması başlıklı TürkCMK m. 76'ya denk gelen hüküm ise AlmCMK m. 81c içerisinde öngörülmüştür.

TürkCMK m. 78 (79 ve 80) ile karş1laştırılabilecek "moleküler genetik incelemeler" başlıklı AlmCMK m. 81e moleküler genetik incelemeye ilişkin esasları öngörmektedir. TürkCMK m. 78 I'e göre "75 ve 76 ncl maddelerde öngörülen işlemlerle elde edilen örnekler üzerinde, soybă̆ının veya elde edilen bulgunun şüpheli veya sanı̆̆a ya da mă̆dura ait olup olmadı̆̆ının tespiti için zorunlu olması halinde moleküler genetik incelemeler yaplabilir. Alınan örnekler üzerinde bu amaçlar dışında tespitler yapılmasına yönelik incelemeler yasaktır." Buna karşın AlmCMK m. 81e I, 81a I ve 81c kapsamında elde edilen örnekler üzerinde, sadece soybağının veya elde edilen bulgunun şüpheli veya sanığa ya da mağdura ait olup olmadığının tespiti için gerekli olması halinde değil, aynı zamanda kişinin cinsiyetinin tespiti için de moleküler genetik inceleme yapılabileceğini öngörmektedir. Buna ek olarak AlmanCMK m. 81 I son cümlede de, alınan örnekler üzerinde hükümde anılan amaçlar dışında incelemeler yapılması yasaklanmaktadır. CMK m. 78 ile alakalı olarak de lege ferenda öncelikle madde kapsamında alınan örneklerden ayrıca cinsiyet tespitinin yapılabilmesinin önünün açılması yerinde olur. Zirâ cinsiyetin açıkça ortada olduğu bazı durumlarda her profilin taranmasındansa, sadece o cinsiyete yönelik taramada bulunma zaman kazandırmaktadır.

Alman m. 81e II, TürkCMK m. 78 II ile çok yakın olmakla birlikte farklı formüle edilmiştir. Buna göre Alman hükmünde "Birinci fikra uyarınca yapılabilen incelemeler, bulunan, muhafaza altına alınan ya da el konulan örnekler üzerinde de yapılabilir. Fıkra 1 cümle 3 ve m. 81 a III ilk yarım cümle bu halde de uygulanır." 
ifadesine yer verirken Türk hükmü "Birinci fikra uyarınca yapılabilen incelemeler, bulunan ve kime ait olduğu belli olmayan beden parçaları üzerinde de yapllabilir. Birinci fikranın ikinci cümlesi, bu halde de uygulanır." düzenlemesinde bulunmuştur. Dolayısıyla AlmCMK “kime ait olduğu belli olmayan beden parçaları" kavramlarını kullanmak yerine doğrudan muhafaza altına alma ve elkoyma tedbirine yer vermiştir. Muhafaza altına alma ve elkoyma tedbirini öngören AlmCMK m. 94, kan izi, mide içeriği, idrar ya da insana ya da cesede ait bir vücut parçası vs. gibi unsurların da madde kapsamında yer alan "eşya" kapsamında olduğunu kabul ettiğinden, ${ }^{150}$ tedbiri içine alan bir üst kavram kullanmayı tercih etmiştir. TürkCMK m. 123 de "Íspat aracı olarakyararlı görülen ya da eşya [...]” hükmünün, özellikle hiç kimsenin zilyetliğinde olmayan sahipsiz eşyalar bakımından geçerli olacağı kabul edilmektedir. ${ }^{151}$ TürkCMK m. 75 ve 76, sadece şüpheli/sanık/mağdur hakkındaki beden muayenesi ve vücuttan örnek almayı öngördüğünden, kime ait olduğu belli olmayan ceset parçalarının, kan izleri, mide içeriği, semen vs. gibi örneklerin TürkCMK m. 123 kapsamında taşınabilir eşya olduğunu kabule engel bir durum bulunmamaktadır. Kaldı ki bu örnekleri CMK m. 78 II kapsamında incelemeye tabi tutmak için bunları öncelikle muhafaza altına almak gerekmektedir. Şu hâlde AlmanCMK hükmü, TürkCMK hükmüne göre daha belirli ve ayrıntılı bir düzenleme getirmiş, bu bakımından hangi tedbirin uygulanacağı tartışmalarının da önüne geçmiştir.

TürkCMK m. 79 ve 80’e denk gelebilecek AlmCMK m. 81f, moleküler genetik inceleme usulüne ilişkindir. TürkCMK m. 79 II gibi AlmCMK m. 81f II de bilirkişilikle ilgili usul işlemlerine yöneliktir. Buna karşın hükümlerin birinci fikraları, bazı farklılıklar göstermektedir.

TürkCMK m. 79 I'e göre, “78. madde uyarınca moleküler genetik incelemeler yapılmasına sadece hâkim karar verebilir. Kararda inceleme ile görevlendirilen bilirkişi de gösterilir." Buna karşılık AlmanCMK m. 81f I, ilgilinin yazılı rızasının bulunmaması durumunda m. 81e I kapsamında yaplacak incelemelere sadece mahkemenin değil, gecikmesinde tehlike bulunması durumunda savcılık ve savcıliğın soruşturma görevlilerinin de karar verebileceğini öngörmektedir. Hüküm ayrıca rıza veren kişinin, elde edilen verilerin hangi amaçla kullanılacağ̀ konusunda aydınlatılmasını zorunlu tutmaktadır.

150 Daha fazla örnek için Meyer-Goßner/Schmitt, StPO, § 81e s. 339.

151 Bkz. Şahin, CMH I, s. 334. 
Bu hüküm TürkCMK hükmünden birçok açıdan ayrılmaktadır: Öncelikle Türk hükmünde ilgilinin rızasına ilişkin bir düzenleme bulunmamaktadır. Bize göre TürkCMK hükmü tedbire karar için sadece hâkim kararı verilebileceğini emrettiğinden, ilgilinin rızası ile moleküler genetik incelemede bulunmak hukuken mümkün olmasa gerekir. Yargıtay ${ }^{152}$ uygulamaları ve öğreti görüşleri ${ }^{153}$ de bu yöndedir. Bu bağlamda de lege ferenda ilgilinin rızası hükmünün madde kapsamına alınması yerinde olacaktır. Zirâ bu durum suçların aydınlatılmasında efektifliği ve hızı, hukuka uygun bir şekilde arttıracaktır. Bunun haricinde AlmCMK hükmü sadece $\mathrm{m}$. 81e birinci fıkra için hâkim kararı öngörmekte, AlmCMK m. 81e II kapsamındaki bulunan, muhafaza altına alınan ya da el konulan örnekler üzerinde DNA analizi yapılabilmesi için hâkim kararına gerek görmemektedir. Bu bağlamda öğreti $^{154}$ ve uygulamada ${ }^{155}$ bu tür örnekler üzerinde incelemede bulunulmasına savcılığın ya da savcılığa bağlı kolluğun karar vereceği ifade edilmektedir. Buna karşın TürkCMK m. 79, CMK m. 78 I ve II'yi kapsar nitelikte kaleme alındığından, m. 78 II kapsamında bulunan ya da kime ait olduğu belli olmayan beden parçaları üzerinde DNA analizi yapılması için de hâkim kararının aranması gerekmektedir. Öğreti ${ }^{156}$ ve uygulama ${ }^{157}$ da görüşler genel olarak bu yöndedir. Ancak Alman hukukuna benzer bir düzenlemenin de lege ferenda Türk hukuku bakımından da öngörülmesi yerinde olacaktır. Zirâ sahipsiz materyaller bakımından ortada temel haklarına saldırıda bulunan somut bir birey bulunmadığı gibi, - dolayısıyla iki fikra arasında temel haklara saldırı bakımından büyük farklar bulunmaktadır - uygulamanın, makul sürede suçları aydınlatma ve usul ekonomisine olumlu etkisinin olacağından da şüphe yoktur. ${ }^{158}$ Ancak hüküm içerisinde savcılık kararının gerekli olduğunun ve kararda “inceleme ile görevlendirilen bilirkişinin de gösterileceği” ile TürkCMK m. 79 II hükümlerine uyulması konusuna atıf yapılması yerinde olacaktır.

152 Yargitay 13. CD, E: 2012/17565 K: 2012/23123 T: 7.11.2012, iç: http://www.savasbaytok.av.tr/index. asp?sayfa=1337, son erişim: 18.12.2016: "Mağdurun rızast varsa beden muayenesi ve vücudundan örnek alınması için hâkim veya Cumhuriyet Savcısından karar alınmasına gerek yok ise de; 5271 sayll CMK'nın 78 ve 79/1. maddeleri uyarınca, mağdurdan alınan kan örneği ile suç konusu araçtan elde edilen bulguların karşılaştırılması, diğer bir ifadeyle moleküler genetik inceleme işleminin yapılabilmesi için hâkim kararını bulunması gerektiği gözetilmelidir."

153 Yenisey/Nuhoğlu, CMH, s. 657.

154 Hepsinin yerine Meyer-Goßner/Schmitt, StPO, § 81e s. 313.

155 LG Potsdam, NJW 2006, s. 1224.

156 Yenisey/Nuhoğlu, CMH, s. 656, 657, 660.

157 Yargitay 13. CD, 07.11.2012, E: 2012/17565, K: 2012/23123, iç: Yenisey/Nuhoğlu, CMH, s. 657, dipnot: 297, s. 660; ayrica 6. CD, E: 2009/18701, K: 2011/5063, T: 11.04.2011, iç: http://www.kararara.com/ yargitay/yrgty_2011/yrgtyk14894.htm, son erişim: 18.12.2016.

158 Benzer ve diğer görüşler için Senger, NJW 2005, s. 3029. 
Bundan sonraki yasal düzenlemeler materyallerin imhası ile DNA verilerinin yok edilmesine ilişkin olup, Almanya ve Türkiye bakımından önemli farklılıklar bulunmaktadır. Zirâ materyallerin imhası bakımından iki ülke yasal düzenlemeleri arasında çeşitli farklılıklar bulunsa da; esas farklılığın verilerin silinmesi hakkında olduğu sabittir. Zira Almanya'da tüm DNA profilleri yok edilmemekte, belli şartları taşıyanların(AlmanCMK m. 81g'de anılan) sisteme kaydedilecekleriöngörülmektedir. Böyle bir hüküm Türk hukukunda bulunmamaktadır.

Alman hukukunda AlmCMK m. 81g koşullarının oluşması durumunda gelecekteki yargilamalarda kullanılmak üzere DNA profillerinin silinmeyerek DNA veri bankalarında kaydedilebileceği kabul edilmektedir. Şu hâlde bu şartları taşımayan veriler gecikmeksizin silinecektir. Ceza yargılaması kapsamında elde edilen verilerin kişisel veri olması sebebiyle, özel bir zarf içerisinde ceza dosyasına konulması gerektiği belirtilmektedir. ${ }^{159}$ Şüpheli/sanık ya da mağdura ait kişisel verilerin yani DNA profilinin çıkarıldığı örneklerin yok edilmesi ise, AlmanCMK m. 81a III ve 81c V'e dayanılarak gerçekleştirilmekte ve bu kapsamda örnekler ceza yargılamasında artık bunlara ihtiyacın ortadan kalktığ 1 anda gecikmeksizin yok edilmektedir. Buna karşın şüpheli/sanık/mağdura ait olmayan AlmanCMK m. 80e II kapsamındaki bulunan ya da muhafaza altına alınan ya da elkonulan örnekler için yok etme yükümlülüğü bulunmamaktadır. Zira AlmanCMK m. 80e II ikinci cümlede " $F$ lkra 1 cümle 3 ve m. 81a III ilk yarım cümle bu halde de uygulanır." demekle, m. 81a III ilk yarım cümleyi (ki burada bu örneklerin mevcut ya da yürütülen başka bir yargılamada kullanılabileceği öngörülmekte) kapsama almakta; ondan sonra gelen gecikmeksizin yok etmeye ilişkin cümleyi kapsam dışı bırakmaktadır. Öğretide ${ }^{160}$ de bu şekilde bulunan, sahipsiz örneklerin yok edilmeyip saklanacakları, zira bunların yok edilmesi hâlinde bunlara ileride bir daha erişilmesinin mümkün olamayacağı ifade edilmektedir.

Türk ceza muhakemesi hukukunda "Genetik inceleme sonuçlarının gizliliği" başlıklı CMK m. 80 “75, 76 ve 78 inci madde hükümlerine göre alınan örnekler üzerinde yapılan inceleme sonuçlarl, kişisel veri niteliğinde olup, başka bir amaçla kullanılamaz; dosya içeriğini öğrenme yetkisine sahip bulunan kişiler tarafindan bir başkasına verilemez. Bu bilgiler, kovuşturmaya yer olmadiğı kararına itiraz süresinin dolması, itirazın reddi, beraat veya ceza verilmesine yer olmadığı kararı verilip

159 Münchener Kommentar-Trück, StPO, m. 80e pn. 27.

160 Hepsinin yerine Münchener Kommentar-Trück, StPO, m. 80e pn. 26. 
kesinleşmesi hâllerinde Cumhuriyet savcısının huzurunda derhâl yok edilir ve bu husus dosyasında muhafaza edilmek üzere tutanağa geçirilir." hükmüyle elde edilen örneklerin yok edilmesini değil, inceleme sonuçları ve bilgilerin ${ }^{161}$ silinmesini öngörmüştür. Elde edilen örneklerin yok edilmesine ilişkin TürkCMK m. 75 ve 76 içerisinde de bir düzenleme bulunmamaktadır. ${ }^{162}$ Ceza Muhakemesinde Beden Muayenesi, Genetik İncelemeler ve Fizik Kimliğin Tespiti Hakkında Yönetmelik m. 14 de bu konuda aydınlatıcı bir hükme yer vermemiştir: "Bu Yönetmelik hükümlerine göre alınan örnekler üzerinde yapılan inceleme sonuçlart, kişisel veri niteliğinde olup, başka bir amaçla kullanılamaz; dosya içeriğini öğrenme yetkisine sahip bulunan kişiler tarafindan bir başkasına verilemez. Bu bilgiler, kovuşturmaya yer olmadı̆̆ kararına itiraz süresinin dolması, itirazın reddi, beraat veya ceza verilmesine yer olmadı̆̆ kararı verilip kesinleşmesi hâllerinde Cumhuriyet savcısının huzurunda ve uygun göreceği usullerle yok edilir ve bu husus dosyasında muhafaza edilmek üzere tutană̆a geçirilir. Olay yerinden elde edilen diğer delillere ilişkin hükümler saklıdır. Bilirkişi tarafindan yapılan analizler sonucu elde edilen bulgular ilgili makama gönderilir; bulgular üzerinden moleküler genetik analizler için izole edilen DNA örnekleri bilirkişi tarafindan rapor hazırlandıktan sonra imha edilir ve bu husus raporda açıkça belirtilir."

Şu hâlde Türk hukukunda de lege lata DNA profili çıkarıldıktan ve profil makama gönderildikten sonra kişisel veri mahiyetindeki DNA profillerinin (istisnas $z^{163}$ ) silinmesi esastır. Yönetmelik’te öngörüldüğü üzere “Bilirkişi tarafından yapılan

161 Yenisey/Nuhoğlu, CMH, s. 659; bilgiler deyiminden neyin kast edildiğinin belli olmadığını haklı olarak dile getirmekte ve burada söz konusu olanın CMK m. 80 I'de olduğu gibi, CMK m. 75-76 ve 78 uyarınca elde edilen bilgiler olduğunu ifade etmektedirler.

162 Krş. Yenisey/Nuhoğlu, CMH, s. 659.

163 Buna karşın Özbek/Diğerleri, CMH, s. 539, mahkûmiyet kararı verildiğinde verilerin kaydedilmesi gerektiğini savunmaktadırlar; Şahin/Göktürk, CMH II, s. 86, ise dava açılmadığında ya da mahkûmiyet dışında esasa ilişkin bir karar verildiğinde verilerin imhası gerektiğini ifade etmektedirler; Yenisey/ Nuhoğlu, CMH, s. 658, ise, yok etme işleminin yapılmasını emreden hâller sayma yöntemi ile gösterilmiş olduğundan, bunlar dışındaki kararların verilmesi durumunda bu bilgilerin yok edilmesi gerekmediği sonucu ortaya çıkmakta olduğunu, bu durumda özellikle mahkûmiyet kararı hâlinde bilgilerin muhafazasının mümkün kılındığını ifade etmektedirler.

Bununla birlikte bize göre normun ratio legisi ve koruma amacı ile şüpheden özgürlük yararlanır ilkesi, bu yorumlara engel teşkil eder gözükmektedir. Zira norm DNA verilerin belirli somut olaylarda mutlaka silinmesine özel önem vermiştir. Kanun koyucunun mahkûmiyet hâlini özellikle norm dışı bıraktığına yönelik bir veri bulunmamaktadır. Ayrıca normda mahkûmiyet hâlinde kişisel veri niteliğindeki DNA profillerinin sistemde kayıtlı kalacaklarına ilişkin belirli bir hüküm getirmemiştir. Nitekim kayıt süresi ve sistemden silmeye ilişkin herhangi bir ilave hüküm de öngörülmemiştir. Şu hâlde DNA profillerinin kanun seviyesinde yasal bir düzenleme bulunmadan herhangi bir sistemde kayıtlı tutulmaları, temel hakka saldırı teşkil edecektir. Bu durumda şüpheden özgürlük yararlanır ilkesi gereği ilgili normun, mahkumiyet hâlinde DNA profillerinin silinmemesine yasal dayanak teşkil etmemesi icap etmektedir. 
analizler sonucu elde edilen bulgular ilgili makama gönderilir". DNA profilini içeren belge bir bilirkişi raporu niteliğindedir ${ }^{164}$ ve her bilirkişi raporu gibi bunun da dava dosyasına konulması gerekmektedir.

Bununla birlikte Yönetmelik’te her ne kadar üzerinden moleküler genetik analizler için izole edilen DNA örnekleri bilirkişi tarafindan rapor hazırlandıktan sonra imhâ edilir ifadesi yer alsa da bize göre DNA örneği kelimesi, hem analiz edilecek DNA materyalini hem de analizden elde edilen DNA profilini kapsar nitelikte yanlış anlamalara müsait olduğundan isabetsiz olup; yeteri kadar açık ve belirli değildir. Bu nedenle profil elde edilen materyalin (kan, sperm vs.) yok edilmesine yönelik herhangi bir düzenleme bulunmadığı kabul edilebilir. ${ }^{165}$ Her ne kadar maddenin ratio legisinden biyolojik örneklerin de yok edileceği haklı olarak ifade edilebilecek olsa da, ${ }^{166}$ "kendisinden DNA profili elde edilen materyalin (biyolojik örneğin)" de yok edileceği hususunda açık bir hükme ihtiyaç bulunmaktadır. Yine her ne kadar Yönetmelik’te “Olay yerinden elde edilen diğer delillere ilişkin hükümler saklıdır.” hükmü yer alsa da, Yönetmelik kapsamında buna yönelik herhangi başka bir açıklama yapılmamaktadır. Şu hâlde özellikle sahipsiz örneklere ne olacağı belirsizdir. En nihayetinde de lege ferenda, mağdur/sanık/şüpheliden elde edilen biyolojik örneklerin yargılamada kendilerine ihtiyacın ortadan kalktığı durumlarda yok edileceğine; buna karşın olay yerinden elde edilen sahipsiz örneklerin saklanacağına ilişkin açık bir hükmün, CMK'da yer alması yerinde olacaktır.

\subsubsection{Avusturya ve İsviçre Ceza Muhakemesinde Ortak Hükümler}

Avusturya Ceza Muhakemesi Kanunu'nun soruşturma aşamasında kimliklendirmeye ilişkin ikinci bölümünde yer alan 124. madde içerisinde "moleküler genetik inceleme" başlıklı benzer bir hüküm yer almaktadır. Hükmü Türk ve Alman normlarından ayıran en önemli özellik moleküler genetik incelemelerin yapılmasına mahkeme tarafından uygun bulunması koşuluyla savcının karar verecek olmasıdır. Kanun ayrıca Güvenlik Güçleri Kanunu'nun ilgili hükümlerinin saklı olduğunu belirtmektedir. İsviçre'de DNA analizleri başlıklı m. 255 DNA analizine ilişkin genel koşulları, m. 256 kitleler üzerinde yapılacak DNA analizlerini, m. 257 hükümlülerden

164 Aynı görüşte Yenisey/Nuhoğlu, CMH, s. 659.

165 Buna yönelik eleştiriler için Ünver/Hakeri, CMH, s. 488; uygulamada da örneklerin ve profillerin yok edilmesinin çeşitli sıkıntılar yarattığı ortadadır. En son olarak bkz. http://www.posta.com.tr/kan-ornekleriimha-edildi-mezar-acilacak-haberi-137898, son erişim: 18.12.2016.

166 Bu görüşte Yenisey/Nuhoğlu, CMH, s. 659. 
çıkarılacak DNA profillerine ilişkin hükümleri norma bağlamıştır. İsviçreCMK m. 255 I, suçların aydınlatılması için şüpheli/sanıktan, diğer kişilerden - özellikle mağdurlardan ya da şüpheliden ayrılmasını sağmak için zorunlu olduğu sürece olay yeri ilişiği bulunanlardan - ölülerden, fiil için önem addeden biyolojik materyallerden örnek alınabileceğini ve bunların DNA profillerinin çıkarılabileceğini öngörmektedir. İkinci fikrada kolluğun kişilerden invaziv olmayan örnek alma işlemine ve fiil için önemli olan biyolojik materyallerden DNA profili çıkarılmasına ilişkin karar verebileceği öngörülmektedir. İsviçreCMK m. 258, invaziv örnek alma işleminin sadece hekimler ya da diğer tıbbi personel tarafından gerçekleştirilebileceğini; $\mathrm{m}$. 259 ayrıca DNA Profil Kanunu'nun da uygulama bulacağını öngörmektedir.

\subsection{Adlî DNA Analizlerine İlişkin Ortak Olmayan Hükümler}

Türkiye'de DNA profillerinin gelecekteki yargılamalarda kullanılmak üzere DNA veri bankalarında saklanması mümkün değildir. Ayrıca kitlesel moleküler genetik incelemelere ilişkin bir hüküm de bulunmamaktadır. Buna karşın Almanya, İsviçre ve Avusturya bu konuda uzun zaman önce önemli adımlar atmışlardır. Aşağıda bu ülkelerdeki yasal düzenlemelere yer verilecek, bunun ardından DNA profillerinin DNA veri bankalarında kaydedilmesine ilişkin istatistikî veriler ele alınarak, Türkiye bakımından de lege ferenda önerilerde bulunulacaktır.

Almanya'da "DNA kimlik tespiti”" başıklı AlmCMK m. 81g, şüpheli/sanığın ağır bir suçtan ya da cinsel dokunulmazlığa karşı işlenen bir suçtan şüpheli olması durumunda, ilerideki bir ceza yargılamasında kimliğini tespit amacıyla kendisinden hücre örneklerinin alınabileceğini, DNA profilinin oluşturulabilmesi veya cinsiyetin tespit edilebilmesi için moleküler genetik incelemeye tabi tutulabileceğini öngörmektedir. Ancak bunun için bazı koşulların oluşması gerekmektedir. Öncelikle fiilin türü ve işleniş tarzı, şüpheli/sanığın kişilik özellikleri ya da diğer veriler, faile karşı ağır bir suçtan dolayı ileride bir ceza yargılamasının vuku bulabileceğine işaret etmek zorundadır. Hükümde, diğer suçların tekrar edilerek işlenmesinin, ağır bir suçun haksızlık içeriği ile aynı derecede olduğu ifade edilmektedir. Bu kapsamda alınan vücut örnekleri sadece hükümde anılan moleküler genetik incelemeler amacıyla kullanılabilir, bu husustaki gereklilik ortadan kalktığında gecikmeksizin imha edilmek zorundadırlar. Ayrıca moleküler genetik inceleme sırasında cinselliğin tespiti ya da DNA profili çıkarılması dışında bir tespitte bulunulmasını kanun açıkça yasaklamıştır. 
Hükmün üçüncü fikrasında, vücuttan örnek alınmasına, şüpheli/sanığın yazılı rızası olmaması durumunda yalnızca mahkeme, ancak gecikmesinde sakınca bulunan durumlarda ayrıca savcılık ve savcılığın soruşturma görevlilerince karar verilebileceği öngörülmüştür. Ancak alınan örnekler üzerinde moleküler genetik incelemede bulunma kararını şüpheli/sanığın yazılı rızası olmadığ 1 durumlarda sadece hâkimin verebileceği öngörülmektedir. Rıza veren kişinin elde edilen verilerin hangi amaçla kullanılacağı konusunda aydınlatılmasına da norm içerisinde ayrıca yer verilmiştir. Üçüncü fikra mahkemenin bu hükme dayanarak karar vermesinin gerekçeli olması gerektiğini ve gerekçenin her somut olayın özelliklerine göre ayrı ayrı irdelenerek ele alınmasını emretmektedir. Gerekçede hangi hususların inceleme konusu yapılması gerektiği de normda ayrıca tespit edilmiştir. Bunlar: Suçun ağırlığı konusunda karar vermede göz önünde bulundurulan olgular, ileride sanık/şüpheliye karşı bir ceza yargılamasının yapılabileceğini kabule gerekçe oluşturan tüm bilgi ve veriler ve en nihayetinde belirleyici öneme sahip her durumun değerlendirmeye alınmasıdır.

Hükmün dördüncü fikrasında, ilk üç fikrada anılan hükümlerin, ilgili kişi hakkında bir fiilden dolayı kesinleşmiş bir karar bulunması ya da haklarında bir hüküm bulunmasa ve adlî sicil kaydı olmasa da şu kişiler bakımından da aynen uygulama bulacağını belirtmektedir: Kusur ehliyetinin bulunmadığı haller, akıl hastalığ1 nedeniyle dava ehliyetsizliği hâlleri, GençlikK m. 3 kapsamında sorumsuzluk bulunması hâli.

Hükmün beşinci fikrası hem bu madde kapsamında hem de bu maddedeki koşulları sağlayarak m. 81e I, II kapsamında elde edilen verilerin Federal Suçlar Bürosu'nda kaydedileceğini ve Federal Suçlar Bürosu Kanunu kapsamında kullanılacağını öngörmektedir. F1krada, verilerin ceza yargılaması, tehlikenin önlenmesi ve uluslararası adlî yardımlaşma amacıyla aktarılabileceği öngörülmüştür. m. 81e I'e dayanılarak elde edilen verilerin sahibi şüpheli ya da sanık yararına olarak, kayıttan önce gecikmeksizin bilgilendirmede bulunarak, arzu ederse bu konuda bir hâkim kararı isteme hakkının bulunduğunun bildirilmesini emretmiştir.

AlmanCMK m. 81h, kitlesel DNA analizlerine ilişkindir. Hüküm, belirli olguların, hayata karş1, vücut bütünlüğüne karşı, kişisel özgürlüğe karşı ya da cinsel dokunulmazlığa karşı bir suçun işlendiği şüphesine gerekçe yaratmasını öngörmektedir. $\mathrm{Bu}$ şekilde gerekçelenmiş bir şüphe bulunması durumunda "muhtemelen faile ait bazı özelliklere sahip olan belirli kişilerden", bunların yazılı rızaları da alınarak, vücut örneği alınabileceğini, alınan örneklerin, DNA profili 
çıkarmak ya da cinsiyeti belirlemek için moleküler genetik incelemeye tabi tutulabileceğini ve elde edilen profillerin diğer mevcut iz örneklerinden alınan DNA profilleri ile programlar aracılığı ile karşılaştırılabileceğini öngörmektedir. Ancak bunun için, eldeki iz örneklerinin bu kişilere ait olup olmadığının tespitinin mutlaka gerekli olması ve tedbirin özellikle ilgili kişi sayısı ile işlenen fiilin ağırlığı açısından orantılı olmas1 gerekmektedir.

Maddenin ikinci fikrasında bu tedbire sadece mahkemenin karar verebileceğini ve kararın yazılı olması gerektiği öngörülmektedir. Kararın gerekçeli olması ve ilgili kişilerin tedbir için belirleyici addedilen özelliklerinin gerekçelendirilmesi gerekmektedir. Kişilerin önceden dinlenmesine gerek yoktur. Tedbir kararına karş1 itirazda da bulunulamaz.

Üçüncü fikrada tedbirin gerçekleştirilmesi için, $\mathrm{m}$. $81 \mathrm{fII}$ ve m. $81 \mathrm{~g}$ II de uygulama bulacağı yer almaktadır. Ayrıca suçun aydınlatılması için artık gerekli olmadığ durumlarda elde edilen tüm DNA profillerinin gecikmeksizin silinmesi, silme işleminin mutlaka belgelendirilmesi gerektiği öngörülmektedir.

Dördüncü fikrada, bu tedbirin sadece ilgilinin rızası ile gerçekleştirilebileceği hususunda ilgili kişinin yazılı olarak aydınlatılmasını emretmektedir. Aydınlatma ayrıca şu bilgileri içermelidir: Vücut örneklerinin sadece birinci fikrada anılan incelemeye tabi tutulacağ 1 ve artık gerek kalmadığ 1 durumda gecikmeksizin yok edileceği, tespit edilen DNA profilinin gelecek ceza yargılamalarında kullanılmak üzere Federal Suçlar Bürosundaki DNA veri bankalarına kaydedilmeyeceği.

Avusturya'da, DNA kimlik tespiti başlıklı AlmCMK m. 81g'ye denk gelebilecek bir düzenleme, CMK içerisinde değil, tam tersine Güvenlik Güçleri Kanunu'nun "DNA İncelemesi" başlıklı 67. maddesinde öngörülmüştür. Bu hükmün CMK'da değil, tam tersine kolluğun görev ve yetkilerini düzenleyen bir kanunda öngörülmüş olması, kanun koyucunun ilerideki ceza yargılamalarında kimliklendirmede kullanılmak üzere DNA analizi yapılarak profillerin kaydedilip, verilerin yeniden kullanılmasını, kolluğun görev alanına giren "kimlik bilgilerinin tespiti amaçlı bir işlem” olarak gördüğünü göstermektedir.

67. maddeye göre DNA incelemesi yapılarak kimlik bilgileri tespiti amaçlı yapılacak bir işlem, şu şartlarda hukuka uygun kabul edilmektedir: İlgili kişinin, cinsel dokunulmazlığa karşı bir suç ya da en az bir yıl özgürlüğü bağlayıcı ceza öngören kasten işlenebilen bir suç işlemiş olduğu yönünde bir şüphe bulunması 
gerekmektedir. $\mathrm{Bu}$ şüphenin yanında, fiilin türü ve işleniş şekli ya da ilgilinin kişiliği nedeniyle, ilgilinin ileride tehlikeli saldırılarda bulunacağ 1 ve arkasında DNA profili aracılığı ile yeniden tanınmasını sağlayacak bir iz bırakacağı düşünülmelidir.

Kanun ayrıca mevcut DNA izlerinin değerlendirilmesi için gerekli olması durumunda, m. 65 II kapsamına giren kişiler için de bu şekilde kimlik bilgilerinin tespiti amaçlı işlemde bulunulabileceğini belirtmektedir. m. 65 II'de kolluğun, belirli tehlikeli saldırılara ilişkin unsurları aydınlatmak amacıyla, saldırıda bulunduğu şüphesi altında olmayan ancak iz bırakmış olma ihtimali bulunan insanları da "kimlik bilgilerinin tespiti amaçlı işlemlere" tabi tutmaya yetkili olduğunu belirtilmektedir. Ancak bunun için bu işlemin mevcut izlerin değerlendirilmesi için zorunlu olması gerekmektedir.

M. 67 ayrıca, madde 65a kapsamındaki durumlar ve 66 kapsamındaki cesetlerde de bu şekilde kimlik bilgilerinin tespiti amaçlı işlemde bulunulabileceğini öngörmektedir. m. 65a intihar girişiminde bulunduğu ya da şiddet içeren bir fiilin mağduru olduğu ya da bir kazanın kurbanı olduğu düşünülen insanları kolluğun "kimlik bilgilerinin tespiti amaçl işlemlere" tabi tutmaya yetkili olduğunu öngörmektedir. m. 66 birinci fikra kimliği belli olmayan cesetlerin, ikinci fikra kolluğun, cesedin ölmeden önce tehlikeli bir saldırıya ait mevcut izleri bırakmış olduğuna ihtimal vermesi durumunda, cesedi "kimlik bilgilerinin tespiti amaçlı işlemlere" tabi tutmaya yetkili olduğunu düzenlemektedir.

67. maddenin ikinci fikrasında elde edilen genetik bilgilerin sadece kimlik bilgileri elde etme amacı için kullanılabileceğini öngörmektedir. Moleküler genetik incelemeleri yapacak bilirkişiye tüm inceleme materyali ilgilinin kimliğine vs. ilişkin veriler olmaksızın aktarılacak, kolluk kuvvetleri bilirkişinin sadece kimliklendirmeyi sağlayacak alanda DNA araştırma yapacağını ve kolluğun kimliklendirmeye ilişkin verileri silme yükümlülüğü doğduğu anda da bilirkişinin tüm inceleme materyallerini yok edeceğini sözleşmesel olarak güvence altına almak zorundadır.

İsviçre'de DNA analizleri başlıklı m. 255 DNA analizine ilişkin genel koşulları, m. 256 kitleler üzerinde yapılacak DNA analizlerini, m. 257 hükümlülerden çıkarılacak DNA profillerine ilişkin hükümleri norma bağlamıştır. Kitlesel inceleme başlıklı m. 256, bir suçun aydınlatılması amacıyla savcılığın istemi üzerine mahkemenin, suçun işlenmesi ile alakalı tespit edilmiş belirli unsurları bünyesinde barındıran kişilerden örnek alınması ve bunların DNA profillerinin çıkarılmasına 
karar verebileceğini öngörmektedir. "Hükümlülerden" başlıklı m. 257, mahkemenin vereceği nihai hükmünde aşağıda anılan kişilerden örnek alınmasına ve DNA profillerinin çıkarılmasına karar verebileceğini düzenlemiştir: Kasten işlenebilen bir suçtan dolayl, bir yıldan fazla özgürlüğ̈̈ bağlayıcı cezaya mahkûm edilenler; kasten işlenebilen, hayata, vücut bütünlüğü veya cinsel dokunulmazliğa karşl işlenen suçlardan birine mahkûm olanlar; tedavi ve genel güvenliği koruma amaçlı hakkında güvelik tedbiri kararı bulunanlar.

\section{Gelecekteki Yargılamalarda Kullanılmak Üzere Adlî DNA Analizi Yapılarak Sonuçların DNA Profilleri Veri Bankasına Kaydedilmesi ve Kitlesel Adlî DNA İncelemeleri De Lege Ferenda Öneriler}

\subsection{Suçların Aydınlatılmasında DNA Profilleri ve DNA Veri Bankalarının Yeri}

Çalışmanın ilk bölümünde Türkiye ve Almanya, İsviçre ve Avusturya hukukunda adlî DNA analizlerine ilişkin ortak olan ve olmayan hükümlere yer verilerek ülkeler arası farklılıklar ortaya konulmaya çalışılmıştır. Bu aşamada en önemli farklılık, DNA profillerinin kaydedilmesi ve kitlesel DNA analizleri hükümlerinin Türkiye'de hâlâ mevzuata girmemiş olmasıdır. Çalışmanın bu aşamasında çeşitli verilerle bu eksikliğin suçların aydınlatılmasına olumsuz etkileri ortaya konulmaya çalışılacaktır. En nihayetinde ilgili hususların yasal zemine kavuşması bakımından de lege ferenda önerilerde bulunulacaktır.

\subsection{1. İstatistiklere Göre Suçların Aydınlatılmasında DNA Profilleri}

Almanya' da 2016 sonlarına kadar Federal Suçlar Bürosu kayıtlarında ${ }^{167}$ 1.161.304 adet DNA analiz verisi mevcuttur. Bu verilerin 861.641 âdeti kişilerden elde edilen veriler, 299.663 adedi ise kişi harici ortamlardan yani olay yerinden elde edilen verilerdir. Her ay ortalama 8.900 yeni kayıt yapılmaktadır. Mevzuat gereği ise, ilk yasal düzenlemenin yapıldığı 1998 yılından 2016 sonuna kadar yaklaşık 468.213 veri kayıtlardan silinmiştir. 1998 yılından 30.09.2016'ya kadar 229.430 eşleşme gerçekleşmiş, bunlardan 47.756 olayda fiillerin eşleşmesi söz konusu olmuş, dolayısıyla farklı yerlerden bulunan olay yerlerinde aynı kaynağa ait DNA profili tespit edilmiş; 181.674 defa ise bir kişiye ait DNA profilinin mevcut

167 https://www.bka.de/DE/UnsereAufgaben/Ermittlungsunterstuetzung/DNA-Analyse/DNAstatistik/ dnaStatistik_node.html, son erişim: 29.11.2016. 
örnekle eşleşerek, işılenmiş fiillerin aydınlatılması sağlanmıştır. Bu rakam suçların aydınlatılması bakımından ciddi bir sonuç ortaya koymaktadır. DNA profilleri aracılığıyla aydınlatılmış suçlarda türe göre dağılım büyükten küçüğe doğru şu şekildedir: ${ }^{168}$ Hirsızlık 142.002, yağma ve şantaj 11.839, cinsel dokunulmazlığa karşı suçlar 3.229, vücut dokunulmazlığına karşı suçlar 3.034, hayata karşı suçlar 1.982, mala zarar verme 1.907, genel tehlike yaratan suçlar 1.702, dolandırıcılık/ güveni kötüye kullanma 777, kamu düzenine karş1 suçlar 760, kişisel özgürlüğe karş1 suçlar 219, hakaret 140. AlmanCK içerisindeki suçlarda toplam 7.716; Özel ceza kanunlarındaki suçlardan toplam 5.643. Anılan tüm bu neticeler DNA profillerinin kaydedilmesi sonucunda ulaşılan neticelerdir. DNA profillerini veri bankalarına kaydetmeyen Türkiye ise ne yazık ki hem ulusal ve uluslararası suçların aydınlatılmasında geri kalmakta hem de mevcut analiz sonuçlarını yok ederek, büyük bir kaynak israfında bulunmaktadır. Gerçekten de Türkiye Emniyet Genel Müdürlüğü biyolojik incelemelere ilişkin faaliyet raporları incelendiğinde Türkiye'de önemli sayıda DNA analizi yapıldığg görülmektedir. Örneğin 2015 faaliyet raporuna ${ }^{169}$ göre, biyolojik incelemeler alanında 26.512 uzmanlık talebi raporla cevaplanmış; bu çalışmalarda gönderilen 166.669 numune üzerinde $\mathbf{7 0 0 . 0 2 2}$ analiz gerçekleştirilmiştir. Aynı şekilde 2013 faaliyet raporuna ${ }^{170}$ göre, biyolojik incelemeler alanında, 24.241 uzmanlık talebi raporla cevaplanmış; bu çalışmalarda gönderilen 145.219 numune üzerinde 636.329 analiz gerçekleştirilmiştir. Ancak anıldığ 1 üzere bu kayıtlar DNA veri bankalarında saklanmadan yok edilmekte ve Türkiye en azından anılan bu iki yıl bakımından toplam 1.336.331 analiz sonucunu Alman örneğindeki eşleştirmelere tabii tutamadan çöpe atarak büyük bir kaynak israfinda bulunmakta ve suçların bilimsel verilerle aydınlatılmasında çağın gerisinde kalmaktadır.

\subsubsection{Suçların Aydınlatılmasında DNA Veri Bankaları}

İstatistikî verilerin gösterdiği üzere bugün DNA profilleri, failinin çoğunlukla geride biyolojik kalıntı bıraktığı ve mükerrerliğin en sık görüldüğü cinsel dokunulmazlığa karşı suçlarda değil, hırsızlıktan mala zarar vermeye kadar çok geniş bir alanda suçların aydınlatmasına hizmet etmektedir. Ancak bugün artık sadece

168 https://www.bka.de/DE/UnsereAufgaben/Ermittlungsunterstuetzung/DNA-Analyse/DNAstatistik/ dnaStatistik_node.html, son erişim: 29.11.2016.

169 https:/www.egm.gov.tr/SiteAssets/Sayfalar/StratejiGelistirmeFaaliyetleri/EGM\%20FAALIYET\%20 RAPORU\%202015.pdf, son erişim: 15.12.2016.

$170 \mathrm{https} / /$ www.egm.gov.tr/SiteAssets/Sayfalar/StratejiGelistirmeFaaliyetleri/EGM_2013_Yili_FAALiYET_ RAPORU.pdf, son erişim: 15.12.2016. 
somut olay kapsamında elde edilen sınırlı verilerin kime ait olduğunun belirlenebilmesi için karşılaştırma yapma suçların aydınlatılmasında yeterli olmadığından, çok daha fazla veri imkânı tanıyan DNA veri tabanlarından faydalanılmaktadır. Aktarılan istatistikî verilerden de ortaya çıktığı üzere, bağlantılı olaylar arasındaki ilişkiler tespit edilebildiğinden, belirsizlikler daha erken aşamalarda önlenebilmektedir. Bununla birlikte şüpheli konumundaki birçok kişinin kısa sürede aklanması da sağlanmakta, bu vesileyle de gereksiz yere mağduriyetler önlenmektedir. DNA veri bankaları sayesinde soruşturma yapan birimlerin işi kolaylaşmakta ve suçların aydınlatılmasında daha çabuk ve etkili sonuç alabilmektedirler!

Tüm bu gerekçelerle 1900 yılların sonunda DNA profillerinin kaydedilmesi gereği ortaya çıkmış ve birçok ülkede DNA veri bankası kurulmuştur. Amerika'nın Virginia Eyaleti 1990 yılında DNA veri bankası kuran ilk Eyalet olmuş, bunu bir y1l sonra kurulan diğer 13 veri bankası izlemiştir. 1993 yılında ise FBI CODIS (Combined DNA Index System) adındaki merkezi veri bankası sistemini kurarak, tüm eyalet veri bankalarına ulaşımı sağlamıştır. İngiltere'de ise 1993 yılında "Royal Commission on Criminal Justice", ağır suçlardan hükümlü olanlardan DNA profili çıkarılarak kaydedilmeleri için, ulusal DNA veri bankasının "National DNA Database" kurulması önerisinde bulunmuş ve anılan Banka 1995 yılında kurulmuştur. Bu süreçte Almanya başta olmak üzere sayısız Avrupa ülkesi DNA veri bankası kurmuştur. Ayrıca Almanya'nın Prüm kentinde 27 Mayıs 2005 tarihinde kısaca "Prüm Anlaşması" denilen "Özellikle Terörizmle, Sinır Aşan Suçlarla ve Yasadışı Göç ile Mücadele Amacıyla Sinır Aşan İşbirliğini Derinleştirme Hakkında Sözleşme” (die Vertiefung der grenzüberschreitenden Zusammenarbeit, insbesondere zur Bekämpfung des Terrorismus, der grenzüberschreitenden Kriminalität und der illegalen Migration $)^{171}$ imzalanarak, Sözleşme'ye taraf olan AB üyesi devletlere DNA veri bankalarının kurma ve ortak veri kullanımı imkânı yaratma yükümlülüğ̈̈ getirilmiştir. Her ne kadar Sözleşme ilk aşamada sadece Belçika Krallığı, Almanya Federal Cumhuriyeti, İspanya Krallığı, Fransa Cumhuriyeti, Lüksemburg Büyük Dukalığı, Hollanda Krallığı ve Avusturya Cumhuriyeti arasında imzalanmış olsa da, şu an için Finlandiya, Slovakya ve Ukrayna ve Norveç gibi diğer Avrupa Ülkeleri de Sözleşme'ye taraf olmuştur. Ancak 26 Ağustos 2008'de bu Sözleşme'nin birçok hükmü "2008/615/JI, 23. Haziran 2008” sayı ve tarihli “Özellikle Terörizmle, Sınır Aşan Suçlarla Mücadele

171 Almanca metin için http://www.bmjv.de/SharedDocs/Downloads/DE/PDF/Themenseiten/Strafrecht/ PruemerVertrag.pdf?_blob=publicationFile \&v=1, son erişim: 6.12.2016. 
Amacıla Sınır Aşan İşbirliğini Derinleştirme Hakkında Komisyon Kararı" (Ratsbeschlusszur zur Vertiefung der grenzüberschreitenden Zusammenarbeit, insbesondere zur Bekämpfung des Terrorismus und der grenzüberschreitenden Kriminalität -Ratsbeschluss Prüm) ${ }^{172}$ kapsamında Avrupa Birliği kapsamında yürürlüğe girmiştir. $\mathrm{Bu}$ düzenleme ile $\mathrm{AB}$ Üyesi 27 ülkeye DNA veri bankas1 kurulması ve profillerin otomatik taranması yöntemiyle tüm üye ülkeler arasında veri eşleşmesi ve aktarımına açılması yükümlülüğü getirilmiştir. Dolayısıyla DNA veri bankası kurulması gereği şu anda ulusal bir olgu olmaktan çıkıp, uluslararası bir boyut kazanmıştır.

Türk ceza muhakemesi hukuku doktrininde ${ }^{173}$ DNA bankalarının kurulması görüşünün ağır bastığı görülmekte; uygulama yaşanan olaylar da, DNA profillerinin DNA veri bankalarına kaydedilmesine ve kayıtların erişime açılmasına ne denli ihtiyaç duyulduğunu net bir şekilde ortaya koymaktadır: En son yaşanan Samatya 'da yaşamış olan $M K$ 'yı öldürdüğü iddiasıyla ağırlaştırılmış müebbet hapis istemiyle yargllanan MN'nin yargllandiğl davada, olay yerinden elde edilen ve maktul ve sanığın dışında üçüncü bir kişiye ait DNA profillerinin, Jandarma Genel Müdürlüğ̈̈ ve Emniyet Genel Müdürlüğ̈̈'nün kriminal laboratuvarındaki DNA örnekleriyle karşılaştırılması Mahkeme tarafindan talep edilmiş; şikâyetçilerin avukatının "Adlî Tıp Kurumu'nda faili meçhul cinayetlerin aydınlanması anlamında DNA arşivi bulunmamasını büyük bir eksiklik olarak” gördüğüne yönelik ifadeleri basına yansımıştır. ${ }^{174}$

Bugün için hem CMK kapsamında hem de ayrı özel bir kanun yoluyla yasal düzenlemelere gidilerek DNA verileri sorununun çözülmesi gerekmektedir. Özellikle CMK içerisinde DNA profillerinin veri bankasındaki sisteme aktarılarak eşleştirilmeleri sağlayacak ve ayrıca gelecekteki ceza yargılamalarında kullanılmak üzere kaydedilmesine hizmet edecek yeni yasal düzenlemelerin öngörülmesi gerekmektedir. Aynı şekilde kitlesel DNA analizlerine ilişkin temel bir hükmün de

172 Almanca metin için http://eur-lex.europa.eu/legal-content/DE/TXT/?uri=URISERV\%3Aj10005, son erişim: 6.12.2016.

173 Ünver/Hakeri, CMH, s. 487, 489; Yenisey/Nuhoğlu, CMH, s. 672; Mahmutoğlu, s. 9, son erişim: 15.01.2017; Özbek, CHD, Nisan 2007, Sayı: 1, s. 64, 65; aynı şekilde Özbek, son erişim: 6.1.2017, 1999 CMUK Tasarısında genetik verilerin saklanmasına ilişkin olarak herhangi bir hükmün bulunmamasını "büyük eksiklik" olarak nitelendirmiştir. Yazara göre ayrıca "DNA-Analizi yönteminin daha etkin ve hizlı bir şekilde kullanılması, böyle bir veri bankasının oluşturulmasına bağlıdır.".

174 http://www.dha.com.tr/turkiyenin-kriminal-dna-arsivi-bu-cinayet-icin-didik-didik-edilecek_932624.html, son erişim: 7.1.2017. 
CMK'ya alınması icap etmektedir. Tüm bu hususlara ilişkin önerilere aşağıda ayrıntılı olarak yer verilecektir.

\subsubsection{CMK Kapsamında DNA Profillerinin Kaydedilmesine İlişkin de lege ferenda Öneriler}

i) DNA profillerinin kaydını sağlayacak ayrı bir hükmün de lege ferenda TürkCMK içerisine (örneğin CMK m. 78/A) eklenmesi gerekmektedir. ${ }^{175}$ Aktarıldığı üzere suçların daha hızlı ve fazla aydınlatılması ile efektif bir ceza yargılaması sistemine erişilmesinde yatan kamu yararı böyle bir yasal düzenlemeyi zorunlu kılmaktadır.

Şu hâlde gelecekteki yargılamalarda kullanılmak üzere DNA analizi yapma ve DNA profilini kaydetmeye yönelik tedbir, tıpkı İsviçre ve Almanya'da olduğu gibi CMK içerisinde öngörülmeli, Avusturya örneğinde olduğu gibi Polis Vazife ve Salahiyet Kanunu (örneğin parmak izi ve fotoğrafların kayda alınmasına ilişkin 5. maddeye ekleme vs.) kapsamında ele alınmamalıdır. Zira tedbir her ne kadar yapısal olarak kolluğun tehlikeyi önleme ve önlemsel tedbirlerine benzese de, özünde tehlikeyi ya da bir suçun işlenmesini önleme değil, bir suçu kısa sürede aydınlatma amacı taşımaktadır. ${ }^{176}$ Aynı şekilde Alman hukukunda da tedbirin gerçek bir ceza muhakemesi uygulaması tedbiri olduğu genel kabul görmektedir. ${ }^{177}$ Gerçekten de DNA analizleri sonucu elde edilen DNA profillerinin ileride kullanılmak üzere kaydedilmesi tedbiri suç işlemeyi önlemeyi değil; tam tersine kimliklendirmeye yarayan delilin koruma altına alınmasını sağlayarak, ileride vuku bulacak bir ceza yargılamasının en hızlı şekilde aydınlatılmasını amaçlanmaktadır. Ayrıca DNA analizi ve DNA verilerinin kullanılmasının temel haklara saldırıda bulunması, temel haklara gösterilen önemi dış dünyaya yansıtması bakımından, bize göre bu tedbirin yapısına uymayan kolluk önlemleri arasında değil, tersine çekirdek kanun olan CMK içerisinde öngörülmesine başka bir gerekçe oluşturmaktadır.

ii) CMK m. 78/A kapsamında de lege ferenda hangi suç ve cezalardan dolayı DNA profili kaydı yapılacağı hususunun ayrıca tartışılması gerekir.

Bu kapsamda, öncelikle belirtmek gerekir ki, aktarılan diğer ülkelerde olduğu gibi

175 Aynı görüşte Mahmutoğlu, s. 9, son erişim: 15.01.2017.; Ünver/Hakeri, CMH, s. 489; Özbek, CHD, Nisan 2007, Say1: 1, s. 47 - 76, s. 65; aynı şekilde Özbek, son erişim: 6.1.2017.

176 Krş. Özbek, son erişim: 6.1.2017; aynı şekilde Özbek, CHD, Nisan 2007, Sayı: 1, s. 64; Mahmutoğlu, s. 9 , son erişim: 15.01.2017.

177 BVerfGE 103, s. 30 vd.; SK-StPO, Cilt I, s. 1439. 
"sadece" bazı suçlarda ceza miktarına ya da suçun ağırlığına bakılmaksızın DNA profillerinin otomatik kaydı yerinde olacaktır. Bunun haricinde anılan ülkelerden farklı olarak istatistikî verilerde DNA profilleri aracılı̆̆ıyla en çok aydınlatılan suçlardan olan hırsızlık ve yağma da, suçların aydınlatılmasında yatan kamu yararı nedeniyle, yukarıda anılan suçların yanında öngörülmesi gereken hükümlerden olmalıdır. Müstehcenlik ve fuhuş suçları failliği ile cinsel suçlar; işkence ve eziyet suçu ile vücut bütünlüğüne karşı suç faillikleri anılan suçları işleme potansiyeli taşıdıklarından anılan suçların da buraya ayrıca eklenmesi yerinde olacaktır. $\mathrm{Bu}$ bağlamda hayata karşı suçlar, vücut bütünlüğüne karşı suçlar, işkence ve eziyet suçu, cinsel dokunulmazlığa karşı suçlar, müstehcenlik suçu, fuhuş, hırsızlık ve yağma suçu CMK m. 78/A kapsamında istisnasız bir şekilde açıkça öngörülmelidir.

Açıkça anılan otomatik kayda tabi tutulan bu suçlar dışında hangi suçların CMK m. 78/A kapsamına alınacağı ayrıca tartışılması gereken bir husustur. Öncelikle hangi suçların kapsam dışında bırakılacağı belirlenmelidir. Bu bağlamda: Almanya'da tartışmalı olmakla birlikte ${ }^{178}$, özellikle İsviçre ve Avusturya ceza muhakemesi hukuku açık bir şekilde, taksirli suçlarda DNA profili kaydını gerekli görmemiştir. Bu durum suçun haksızlık içeriği ve temel hakka saldırı arasında orantılı bir durum yarattığından, ayrıca taksirli suç tekrarlama potansiyeli doğaları gereği yüksek olmadığından bunları kapsam dışı bırakmak amaca uygun ve orantılı olacaktır. Şu hâlde taksirli suçlardan DNA profili kaydı yapılmamalıdır.

Bundan sonraki aşamada Avusturya ve İsviçre'de olduğu gibi belirli bir ceza barajı yerine, Alman hukukunda olduğu gibi ağır bir suç unsuru getirmek mi daha yerinde olacaktır sorusuna yanıt vermek gerekir. Biz ağır suç unsuru arayan Alman hukukunun çözümünün isabetli olmayacağı kanaatindeyiz. Zira bu unsurun içeriğini doldurma görevinin uygulama ve teoriye bırakılması hem tartışma yaratmakta hem de mahkemelerin belirsizliklerle mücadele ederek, içtihat yaratmaları zaman ve emek kaybına yol açmaktadır. Bu gerekçeyle ceza miktarına göre suçların esas alınması hukukî güvenlik ve belirlilik ilkesi bakımından daha yerinde gözükmektedir.

Burada önemli olan ölçülülük ilkesi gereklerine uyacak hangi suç ve özellikle ceza miktarının esas alınacaktır:

Almanya "ağır suç" kavramı içerisinde belirli bir ceza miktarını esas almadan, somut olay merkezli hareket etmekte, hem Verbrechen denilen (alt sınırı bir yıl üzeri hapis 
cezası öngören) hem de Vergehen denilen (bir yılın altında hapis cezası ya da adlî para cezası öngören) suçların ağır suç teşkil edebileceğini kabul etmektedir (bir yıl hapis cezası merkezli olarak yapılan Verbrechen ve Vergehen ayrımı tanımı AlmCK m. 12'de yer almaktadır). Avusturya da soyut cezayı esas alarak, en az bir yıl üzerinde özgürlüğü bağlayıcı ceza öngören suçları yeterli görmektedir (Polis Kanunu kapsamındaki düzenleme, Ceza Kanunu m. 17 kapsamında üç yıllık özgürlüğü bağlayıcı cezayı esas alan Verbrechen ve Vergehen ayrımına yer vermeden, sadece suç kavramına yer vermiştir). İsviçre ise hükümlüden örnek alınmasını öngördüğünden, hem soyut hem de somut cezayı baz almış, Verbrechen denilen alt sınırı en az üç yıl ve üzeri olan suçlarda en az bir yıl ve üzeri özgürlüğü bağlayıcı cezaya çarptırılmış olmayı öngörmüştür (Alman hukukunun tersine İsviçre hukukunda Verbrechen üç yıl üzeri özgürlüğü bağlayıcı ceza öngören suçlara, Vergehen ise 3 yılın altında özgürlüğü bağlayıcı ceza öngören suçlara denilmektedir. Tanım İsviçreCK m. 10’da yer almaktadır.).

Türk ceza muhakemesi hukukuna ilişkin bir öneride bulunmadan evvel TürkCMK içerisinde öngörülen bağlantılı diğer tedbirlerde kanun koyucunun nasıl bir irade gösterdiğine göz atmak faydalı olacaktır: CMK m. 75 V gereği şüpheli/sanık üzerinde iç beden muayenesi yapılabilmesi ya da kişiden kan veya benzeri biyolojik örneklerle saç, tükürük, tırnak gibi örnekler alınabilmesi için, ilgili suçun üst sınırının iki yıldan daha fazla hapis cezası olması gerekmektedir. Bu durumda suçta üst sınırı iki yıl üzeri hapis cezası zorunluluğu, diğer kişilerin beden muayenesi ve vücuttan örnek alınması (CMK m. 76) ve moleküler genetik incelemeler (CMK m. 78) için de geçerlidir. ${ }^{179} \mathrm{Bu}$ durumda DNA profili çıkarılabilmesi için öngörülebilecek sınırın en az bu sınırda olması gerekecektir. Aynı şekilde "fizik kimliğin tespiti" (CMK m. 81 I) de üst sınırı iki yıl veya daha fazla hapis cezasını gerektiren bir suçtan dolayı şüpheli veya sanık olan kişiler hakkında mümkün olabilmektedir. Kimliğinin teşhisi için kişinin fotoğrafı, beden ölçüleri, parmak ve avuç içi izi, bedeninde yer almış olup teşhisini kolaylaştıracak diğer özellikleri ile sesi ve görüntülerin kayda alınması söz konusudur.

\section{Özgürlüğü bağlayıcı ceza miktarına bir üst sınır getirilmesi bu bağlamda da üst sınırı üç ve iki yıl olan suçlar gözden geçirildiğinde şöyle bir tablo çıkmaktadır:}

Soyut cezası üst sınırı üç yıl ve altı olan suçlar genel olarak şu şekildedir: İnsan üzerinde deney TCK m. 90 I (bir yıldan üç yıla kadar); yardım veya bildirim 
yükümlülügüüün yerine getirilmemesi m. 98 II (bir yıldan üç yıla kadar); kısırlaştırma m. 101 II (bir yıldan üç yıla kadar); şantaj m. 107 I (bir yıldan üç yıla kadar); siyasal hakların kullanılmasının engellenmesi m. 114 I b (bir yıldan üç yıla kadar); inanç, düşünce ve kanaat hürriyetinin kullanılmasını engelleme m. 115 I (bir yıldan üç yıla kadar); konut dokunulmazlığının ihlali m. 116 IV (bir yıldan üç yıla kadar); iş ve çalışma hürriyetinin ihlali m. 117 II, IV (altı aydan üç yıla kadar); sendikal hakların kullanılmasının engellenmesi m. 118 II (bir yıldan üç yıla kadar); nefret ve ayrımcılık m. 122 I (bir yıldan üç yıla kadar); haberleşmenin gizliliğini ihlal m. 132 I, III (bir yıldan üç yıla kadar); özel hayatın gizliliği m. 134 (bir yıldan üç yıla kadar); kişisel verilerin kaydedilmesi m. 135 I (bir yıldan üç yıla kadar); mala zarar verme m. 151 I (dört aydan üç yıla kadar); hakkı olmayan yere tecavüz m. 154 (altı aydan üç yıla); karşılıksız yararlanma m. 163 III (bir yıldan üç yıla kadar); şirket ve kooperatifler hakkında yanlış bilgi m. 164 (altı aydan üç yıla kadar); suç eşyasının alınması kabul edilmesi m. 165 I (altı aydan üç yıla kadar); genel güvenliğin kasten tehlikeye sokulması m. 170 I (altı aydan üç yıla kadar); radyasyon yayma m. 172 IV (altı aydan üç yıla kadar); çevrenin kasten kirletilmesi m. 181 II (bir yıldan üç yıla kadar); parada sahtecilik m. 197 II (bir yıldan üç yıla kadar); mühür bozma m. 203 (altı aydan üç yıla kadar); özel belgede sahtecilik m. 207 (bir yıldan üç yıla kadar); özel belgeyi bozmak, yok etmek, gizlemek m. 208 (bir yıldan üç yıla kadar); halkı kin ve düşmanlığa tahrik, aşağılama m. 216 I (bir yıldan üç yıla kadar); suç işlemek amacıyla örgüt kurma m. II, VIII (bir yıldan üç yıla kadar); ulaşım araçlarının kaçırılması veya alıkonulması m. 223 (bir yıldan üç yıla kadar); kumar oynanması için yer ve imkân sağlama m. 228 I (bir yıldan üç yıla kadar); dilencilik m. 229 I (bir yıldan üç yıla kadar); çocuğun soybağını değiştirme m. 231 I (bir yıldan üç yıla kadar); ihaleye fesat karıştırma m. 235 III b (bir yıldan üç yıla kadar); kamuya gerekli şeylerin yokluğuna neden olma m. 238 I (bir yıldan üç yıla kadar); ticari sır, bankacılık sırrı veya müşteri sırrı niteliğindeki bilgi ve belgelerin açıklanması m. 139 I (bir yıldan üç yıla kadar); bilişim sistemine girme m. 243 IV (bir yıldan üç yıla kadar); sistemi engelleme, bozma, verileri yok etme veya değiştirme m. 244 II (altı aydan üç yıla kadar); yasak cihaz veya programlar m. 245/A I (bir yıldan üç yıla kadar); irtikâp m. 250 III (bir yıldan üç yıla kadar); denetim görevinin ihmali m. 251 II (üç aydan üç yıla kadar); nüfuz ticareti m. 255 I (bir yıldan üç yıla kadar); görevini yaptırmamak için direnme m. 265 I (altı aydan üç yıla kadar); suç uydurma m. 271 I (üç yıla kadar); yalan tanıklık m. 272 II (bir yıldan üç yıla kadar); gizliliğin ihlali m. 285 I, II (bir yıldan üç yıla kadar); hükümlü ve tutuklunun kaçması m. 292 II (bir yıldan üç yıla kadar); kaçmaya imkân sağlama m. 
294 I, VIII (bir yıldan üç yıla kadar); hükümlü veya tutukluların ayaklanması m. 296 I (altı aydan üç yıla kadar); infaz kurumuna ya da tutukevine yasak eşya sokmak m. 297 II (bir yıldan üç yıla kadar); hak kullanma ve beslenmeyi engelleme m. 298 I (bir y1ldan üç yıla kadar); devletin egemenlik alametlerini aşağılama m. 300 I (bir yıldan üç yıla kadar); askerleri itaatsizliğe teşvik m. 319 I (bir yıldan üç yıla kadar); yabanc1 hizmetine asker yazma, yazılma m. 320 III (bir yıldan üç yıla kadar); seferberlikle ilgili görevin ihmali m. 324 (altı aydan üç yıla kadar).

Soyut cezası üst sınırı iki yıl ve altında kalan suçlar genel olarak şu şekildedir:

Terk m. 97 I (üç aydan iki yıla kadar hapis); yardım veya bildirim yükümlülüğünün yerine getirilmemesi m. 98 I (bir yıla kadar hapis veya adlî para cezası); çocuk düşürtme m. 99 II 2. cümle (çocuğunun düşürtülmesine rıza gösteren kadın bir yıla kadar hapis veya adlî para cezası); çocuk düşürme m. 100 I (bir yıla kadar hapis veya adlî para cezası); tehdit m. 106 I 1. cümle (altı aydan iki yıla kadar hapis cezası), 2. cümle (altı aya kadar hapis veya adlî para cezası); konut dokunulmazlığının ihlali m. 116 I (altı aydan iki yıla kadar hapis cezas1), II (altı aydan bir yıla kadar hapis veya adlî para cezası); iş ve çalışma hürriyetinin ihlali m. 117 (altı aydan iki yıla kadar hapis veya adlî para cezası); sendikal hakların kullanılmasının engellenmesi m. 118 I (altı aydan iki yıla kadar hapis cezası); haksız arama m. 120 (üç aydan bir yıla kadar hapis cezası); dilekçe hakkının kullanılmasının engellenmesi m. 121 (altı aya kadar hapis cezası); kişilerin huzur ve sükûnunu bozma m. 123 I (üç aydan bir yıla kadar hapis cezası); haberleşmenin engellenmesi m. 124 I (altı aydan iki yıla kadar hapis veya adlî para cezası); hakaret m. 125 I (üç aydan iki yıla kadar hapis veya adlî para cezası), III (cezanın alt sınırı bir yıldan az olamaz), kişiler arasındaki konuşmaların dinlenmesi ve kayda alınması m. 133 II (altı aydan iki yıla kadar hapis veya adlî para cezas1); verileri yok etmeme m. 138 I (bir yıldan iki yıla kadar hapis cezası); hırsızlıkdaha az cezayı gerektiren hâller m. 144 (iki aydan bir yıla kadar hapis veya adlî para cezası); kullanma hırsızlı̆̆ı m. 146 I (hırsızlık suçunun bir yıldan üç yıla kadar olan hapis cezası yarı oranına kadar indirilecek); ibadethanelere ve mezarlıkları kirletme m. 153 II (üç aydan bir yıla kadar hapis veya adlî para cezası); güveni kötüye kullanma m. 155 I (altı aydan iki yıla kadar hapis ve adlî para cezas1); bedelsiz senedi kullanma m. 156 I (altı aydan iki yıla kadar hapis ve adlî para cezası); daha az cezayı gerektiren hâl m. 159 I (altı aydan bir yıla kadar hapis veya adlî para cezası); kaybolmuş, veya hata sonucu ele geçmiş, eşya üzerinde tasarruf m. 160 I (bir yıla kadar hapis veya adlî para cezası); karşılıksız yararlanma m. 163 I (iki aydan altı aya kadar hapis veya adlî 
para cezası); II (altı aydan iki yıla kadar hapis veya adlî para cezası); bilgi vermeme m. 166 I (altı aya kadar hapis veya adlî para cezası); genel güvenliğin kasten tehlikeye sokulması m. 170 II (üç aydan bir yıla kadar hapis veya adlî para cezası); akıl hastası üzerindeki bakım ve gözetim yükümlülüğünün ihlali m. 175 I (altı aya kadar hapis veya adlî para cezası); inşaat veya yıkımla ilgili emniyet kurallarına uymama m. 176 (üç aydan bir yıla kadar hapis veya adlî para cezası); hayvanın tehlike yaratabilecek şekilde serbest bırakılması m. 177 ( altı aya kadar hapis veya adlî para cezası); işaret ve engel koymama m. 178 (iki aydan altı aya kadar hapis veya adlî para cezası); trafik güvenliğini tehlikeye sokma m. 179 II, III (üç aydan iki yıla kadar hapis cezas1), çevreyi kirletme m. 181 I (iki yıla kadar hapis cezas1); gürültüye neden olma m. 183 I (iki aydan iki yıla kadar hapis veya adlî para cezası); sağlı için tehlikeli madde temini m. 194 I (altı aydan bir yıla kadar hapis cezası); bulaşıcı hastalıklara ilişkin tedbirlere aykırı davranma m. 195 I (iki aydan bir yıla kadar hapis cezası); usulsüz ölü gömülmesi m. 196 I (altı aya kadar hapis cezası); parada sahtecilik m. 197 III (üç aydan bir yıla kadar hapis cezası); kıymetli damgada sahtecilik m. 199 II (üç aydan bir yıla kadar hapis ve adlî para cezası), III (bir aydan altı aya kadar hapis cezası); resmî belgenin düzenlenmesinde yalan beyan $\mathrm{m}$. 206 I (üç aydan iki yıla kadar hapis veya adlî para cezası); açığa imzanın kötüye kullanılması m. 209 I (üç aydan bir yıla kadar hapis cezası); suçu ve suçluyu övme m. 215 I (iki y1la kadar hapis cezası); halk1 kin ve düşmanlığa tahrik veya aşağılama m. 216 II (altı aydan bir yıla kadar hapis cezas1); III (alt1 aydan bir yıla kadar); kanunlara uymamaya tahrik m. 217 I (alt1 aydan iki yıla kadar hapis veya adlî para cezası); görev sırasında din hizmetlerini kötüye kullanma m. 219 I (bir aydan bir seneye kadar hapis ve adlî para cezası); II (üç aydan iki seneye kadar hapse ve adlî para cezası); hayâsızca hareketler m. 225 I (altı aydan bir yıla kadar hapis cezası); birden çok evlilik, hileli evlenme, dinsel tören m. 230 I, II (altı aydan iki yıla kadar hapis cezası); III (üç aydan bir yıla kadar hapis cezası); kötü muamele m. 232 I (iki aydan bir yıla kadar hapis cezası), II (bir yıla kadar hapis cezası), aile hukukundan kaynaklanan yükümlülüğün ihlali m. 233 I (bir yıla kadar hapis cezası), II (üç aydan bir yıla kadar), III (üç aydan bir yıla kadar hapis cezası); çocuğun kaçırılması ve alıkonulması m. 234 I, II (üç aydan bir yıla kadar hapis cezası), III (üç aydan bir yıla kadar hapis cezası); fiyatları etkileme m. 237 I, II, III (üç aydan iki yıla kadar hapis ve adlî para cezas1); mal veya hizmet satımından kaçınma m. 240 I (altı aydan iki yıla kadar hapis cezası); bilişim sistemine girme m. 243 I, II, III (bir yıla kadar hapis veya adlî para cezas1); görevi kötüye kullanma m. 257 I (altı aydan iki yıla kadar hapis cezası); II (üç aydan bir yıla kadar hapis cezası); 
kamu görevinin terki veya yapılmaması m. 260 I, II (üç aydan bir yıla kadar hapis cezası); kişilerin malları üzerinde usulsüz tasarruf m. 261 I (altı aydan iki yıla kadar hapis cezası); kamu görevinin usulsüz olarak üstlenilmesi m. 262 (üç aydan iki yıla kadar hapis cezası); özel işaret ve kıyafetleri usulsüz kullanma m. 264 I, II (üç aydan bir yıla kadar hapis cezası); suç, üstlenme m. 270 (iki yıla kadar hapis cezası); yalan tanıklık m. 272 I (dört aydan bir yıla kadar hapis cezası); suçu bildirmeme m. 278 I, II, III (bir yıla kadar hapis cezası); kamu görevlisinin suçu bildirmemesi m. 279 I (altı aydan iki yıla kadar hapis cezası); sağlık mesleği mensuplarının suçu bildirmemesi m. 280 I (bir yıla kadar hapis cezası); tutuklu, hükümlü veya suç, delillerini bildirmeme m. 284 I, II, III (bir yıla kadar hapis cezası); ses veya görüntülerin kayda alınması m. 286 (altı aya kadar hapis cezası); genital muayene m. 287 I (üç aydan bir yıla kadar hapis cezas1); adil yargılamayı etkilemeye teşebbüs m. 288 I (elli günden az olmamak üzere adlî para cezası); muhafaza görevini kötüye kullanma m. 289 I, II, III, IV (üç aydan iki yıla kadar hapis ve üç bin güne kadar adlî para cezası); resmen teslim olunan mala elkonulması ve bozulması m. 290 I (üç aydan bir yıla kadar hapis); başkası yerine ceza infaz kurumuna veya tutukevine girme m. 291 (altı aydan iki yıla kadar hapis cezası); hükümlü veya tutuklunun kaçması m. 292 I (altı aydan bir yıla kadar hapis cezası); muhafızın görevini kötüye kullanması m. 295 I (görevi kötüye kullanma suçuna ilişkin hükümler uygulanır: altı aydan iki yıla kadar hapis cezası); II (altı aydan iki yıla kadar hapis cezası); devletin egemenlik alametlerini aşağılama m. 300 II (altı aydan iki yıla kadar hapis cezası); Türk Milletini, Türkiye Cumhuriyeti Devletini, Devletin kurum ve organlarını aşağılama m. 301 I, II (altı aydan iki yıla kadar hapis cezası); yabancı devlet bayrağına karşı hakaret m. 341 I (üç aydan bir yıla kadar hapis cezas1).

Soyut suç sınırının iki veya üç yıl ve altı ya da üç yıl üzeri olarak belirlenmesinde Anayasa'nın 13. maddesi gereği ölçülülük ilkesi gereklerine uyularak; özellikle geride DNA örneği bırakılmasının göreli daha düşük olacağı suçları kapsam dışında bırakarak, işlenen suçun kamu huzuru, barış ve güvenliğini bozucu etkisi ve suçla korunan hukukî değerin önemini göz önünde tutmak yerinde olacaktır. Bu bağlamda ilk aşamada soyut ceza üst sınırı iki yıl veya üç yıl ve altı olan suçlar çoğunlukla DNA profil kaydı kapsamı dışında kalacak suçlar olup, bunlar çoğunlukla üzerinde DNA analizi yapılarak aydınlatılmaya müsait olmayan suçlardır. Kural olarak üst sınırı üç yıl üzeri olan suçların haksızlık içeriği ve korudukları hukukî değerler üst sınırı iki yıl veya üç yıl ve altı olanlara göre daha ağırdır. Bunlar toplumsal barışa daha çok zarar veren suçlardır. Ölçülülük ilkesi elde edilecek, ulaşılmak istenen 
fayda ile verilecek zarar arasında oran aranmasını emrettiğinden, suç soyut ceza üst sınırını amaca hizmet etmeyecek derecede düşürmek elverişsiz ve orantısız olacağından, bu çalışmanın başında anılan temel haklara saldırı teşkil edecektir. Tüm bu gerekçelerle soyut ceza olarak üst sınırı üç yılın üzerinde olan suçlar DNA profili kaydına tabi tutulmalıdır. Üç yıl ve üç yılın altındaki suçlarda DNA profillerinin DNA veri bankalarına kaydı mümkün olmamalıdır.

Tüm bu tespitlerden sonra üst sınırı üç yıl üzeri olan soyut ceza dışında bir de somut cezanın da öngörülüp öngörülmeyeceği ele alınmalıdır. Aktarıldığı üzere İsviçre hukukunda somut ceza bakımından, en az bir yıl ya da daha fazla özgürlüğü bağlayıcı bir cezaya çarptırılmış olanların DNA kaydı yapılmaktadır. Almanya ve Avusturya ağır suçlarda şüpheli/sanık ya da hükümlü olma koşulunun yanında failin kişiliği, fiilin türü ya da işlenişşsekli nedeniyle gelecekte suçun yeniden işlenme tehlikesi bakımından incelemesini aramakla, tehlikeli addedilmeyecek failleri DNA profili açısından kayıt dışı bırakmaktadır. Bizce failin kişiliği merkezli bir tehlikelilik değerlendirmesi değil, İsviçre hukukunda olduğu gibi somut cezayı esas alan ikinci bir elemenin Türk hukukunda öngörülmesi ölçülülük ilkesi bakımından yerinde olacaktır. Zirâ norm somut cezayı değil sadece soyut cezayı öngördüğünde, otomatik bir kayıt sistemi söz konusu olacaktır. Ayrıca somut ceza sınırının belirlenmesi özellikle TCK m. 61 kapsamında cezanın belirlenmesi ve bireyselleştirilmesi hükümleri ile cezanın azalmasına etkide bulunan etkin pişmanlık hükümlerinin göz ardı edilmediğini göstermesi bakımından önemlidir. Bunun yanında TCK m. 50 ve 51 kapsamındaki ceza sınırları göz önünde bulundurulmalıdır. Açıklanan sebeplerle somut ceza sınırının, iki yıl üstü hapis cezası olarak belirlenmesi, ceza hukuku sisteminde bütünlüğün korunması ve ölçülülük ilkesi bakımından isabetli olabilecektir.

Şu hâlde CMK m. 78/A kapsamında DNA profilleri oluşturularak sistemde kaydedilecek hükümlüler, üç yıl üzeri özgürlüğü bağlayıcı ceza öngören kasıtlı suçlardan iki yıl üzerinde hapis cezası alanlar olacaktır. Bunun yanında yukarıda da aktardığımız gibi hayata karşı suçlar, vücut bütünlüğüne karşı suçlar, işkence ve eziyet suçu, cinsel dokunulmazlığa karşı suçlar, müstehcenlik suçu, fuhuş, hırsızlık ve yağma suçunda soyut ve somut ceza sınırlarına bakılmaksızın otomatik kayıt sistemi öngörülecektir.

İki yılın üzerinde özgürlüğü bağlayıcı cezaya çarptırılmış olmak ana kural olmakla birlikte, İsviçre'de olduğu gibi çocuklara özgü güvenlik tedbirleri (TCK m. 56) ve 
akıl hastalarına (ve alkol veya uyuşturucu madde bağımlılarına) özgü güvenlik tedbirleri (TCK m. 57) de önerilen CMK m. 78/A kapsamına de lege ferenda alınabilir. Ayrıca yukarıdaki suçlarda erişkin çocuk ayrımı yapmadan, mevcut ceza sınırlarının dikkate alınması, normun amacına uygun olacaktır.

iii) CMK m. 78/A kapsamında de lege ferenda, sadece hükümlülerin değil, aynı zamanda şüpheli/sanıkların ve sahipsiz materyallerden elde edilen DNA profillerinin DNA veri bankasına alınması ve özellikle şüpheli veya sanıklar bakımından bu statüler son bulana kadar, sahipsiz olanlar bakımından ise uzun bir süre için (örneğin İsviçre'de 30 yıl) sistemde kayıtlı tutulmasını öngörmek isabetli olacaktır. Her ne kadar içeriksel farklılıklar olsa da İsviçre, Almanya ve Avusturya düzenlemeleri şüpheli ve sanığın DNA profillerinin kayıtlarına izin vermektedir.

Bu bağlamda CMK m. 78/A kapsamında hükümlülere ilişkin normdan sonra farklı bir fikra içerisinde mevcut CMK m. 78'e göre alınan ve üç yıl ve üzeri hapis cezası öngören suçlardan şüpheli ya da sanık olanların DNA profilinin DNA bankası veri sistemine aktarılacağının ve görülmekte olan diğer suçlar bakımından eşleştirmelere tabi tutulacaklarının ve en nihayetinde bu statüleri son bulana kadar profillerin burada saklanacaklarının öngörülmesi gerekir. Böylece sisteme aktarılan profil kimliği tespit amaçlı başka profillerle eşleştirilebilecek, ayrıca işlenmiş başka suçlarla da bağlantı kurularak, mevcut faili meçhul suçların aydınlatılması sağlanacaktır. Bunun yanında hem hükümlülerden ve şüpheli/sanıktan alınan hem de sahipsiz DNA profillerinin ne kadar sistemde kayıtlı olacağı ve ne zaman silinmeleri gerektiğinin CMK m. 78/A içerisinde ayrıca ayrıntılı bir şekilde düzenlenmesi; bunun dışındaki hususlar bakımından çıkarılacak DNA Verileri ve Türkiye Milli DNA Veri Bankası Kапипи hükümleri saklı tutulduğu belirtilmesi isabetli olabilecektir.

iv) CMK m. 78/A kapsamına de lege ferenda sadece şüpheli/sanık/hükümlü DNA profillerinin kaydedilmesi için mutlâka mahkeme kararının aranması gerekir.

CMK m. 78/A kapsamında şüpheli ve sanıklardan mevcut düzenlemelere göre sulh ceza hâkimi ya da kovuşturmayı yapan mahkemenin karar vermesi söz konusu olabilecekken, hükümlüler bakımından hükmü veren mahkeme karar verebilecektir.

v) Bunun yanında CMK hükümde DNA profillerinin işlenmesi, kaydı ve verilerin sistemden silinmesi hakkında düzenlemeye gidilmemesi yerinde olacaktır. $\mathrm{Bu}$ hususta DNA Verileri ve Türkiye Milli DNA Veri Bankası Kanunu hükümleri saklı 


\section{tutulmalı ve konu anılan Kanun kapsamında ayrıntılı olarak düzenlenmelidir.}

Gerek CMK uygulamaları gerekse CMK dışı uygulamaları ve bunlara ilişkin usulleri ve diğer ayrıntıları kurallara bağlayacak kanun seviyesinde bir yasal düzenleme yapılmalıdır. İlgili Kanun içerisinde DNA profillerinin hangi durumlar için ne kadar bir süre için sistemde kayıtlı olacağı ve ne zaman silinmesi gerektiği (örneğin sanık ve şüphelilerin bu statülerini sona erdirecek her bir durum ayrı ayrı anılarak, statünün sona ermesi ile verilerin silinmesi; hükümlülerden cezanın infazı, koşullu salıverme ya da güvenlik tedbirleri gibi her bir husus ayrı ayrı göz önünde bulundurarak, 10, 20 vs. yıl gibi bir süre sonra verilerin silinmesi; sahipsiz olan profillerin 30-50 vs. y1l sonra silinmesi vs.), silinmeye hangi durumlarda kimin karar vereceği belirtilmelidir. Bu bağlamda 2007 tarihli DNA Verileri ve Türkiye Milli DNA Veri Bankası Kanunu Tasarısı, hakkında ileri sürülen görüşler de göz önünde bulundurularak ${ }^{180}$ yeniden gözden geçirilerek revize edilmeli ve mutlâka yasalaşmalıdır.

\subsubsection{Kitlesel DNA Analizlerine İlişkin de lege ferenda Öneriler}

Mevcut CMK içerisinde suç şüphelisi ya da sanığı olmadığı hâlde, şüpheli olma potansiyeli olan bir kişi topluluğundan DNA örneği alınmasına, yani kitlesel DNA analizlerine izin veren bir hüküm bulunmamaktadır. ${ }^{181}$ Zira TürkCMK m. 75 şüpheli/ sanıktan; m. 76 mağdurdan örnek alınmasına yasal zemin hazırlamakta; CMK m. 78 II ise bulunan ve kime ait olduğu belli olmayan beden parçaları üzerinde DNA incelemesi yapılabileceğini öngörmektedir. Şu hâlde bunlardan hiç birisi olmayan bir insanlar topluluğundan hangi şartlarda örnek alınacağı ve bunların DNA analizine tabi tutulacağı belirsizdir. Şu hâlde bu gibi durumlar için CMK'ya de lege ferenda yeni bir hükmün (örneğin CMK m. 78/B) eklenmesi icap etmektedir.

Kitlesel DNA analizlerini konu alacak CMK m. 78/B kapsamında de lege ferenda tıpkı TürkCMK m. 78'te olduğu gibi üst sınırının iki yıl ve üzeri hapis cezası gerektiren suçlarda kitlesel DNA analizinin mümkün olabilmesi yerinde olabilir. Ancak buna bağlı olarak da DNA profili çıkarılacak kişilerde bulunması gereken özelliklerin açık ve net bir şekilde tespit edilmiş olması, aydınlatılacak suçla analiz yapılması arasında orantı bulunmasına, tedbirin zorlayıcı değil yazılı rızayla mümkün olacağına ve hâkim kararıyla gerçekleştirilebileceğine vurgu yapılmalıdır.

180 Yenisey/Nuhoğlu, CMH, s. 670 vd.; Özbek, CHD, Nisan 2007, Sayı: 1, s. 71 vd.; Türk Tabipler Birliği Etik Kurul görüşü için http://www.ttb.org.tr/index.php/Etik-Kurul/etik-1369.html, son erişim: 3.12.2016.

181 Aynı görüşte Yenisey/Nuhoğlu, CMH, s. 655; karşı görüşte Ünver/Hakeri, CMH, s. 479, ancak yeni yasal düzenlemeden yana s. 490 . 
Bu bağlamda suç şüphelisi olmamakla birlikte, suçun işlenmesi ile ilgili tespit edilmiş olan bazı unsurları bünyesinde barındıran ya da şüpheliye ait bazı özelliklere sahip kişilerden DNA profili çıkarılmak üzere örnek alınabilir. Kişi DNA analizi amaçlı örnek vermeye zorlanamaz ve örnek vermeyen kişi hakkında suç şüphelisi olduğu çıkarımında bulunulamaz.

DNA analizi amaçlı örnek vermek isteyen kişinin, önceden özellikle profilin sadece mevcut yargılamada eşleşmeye tabi tutulacağı, başka ceza yargılamalarında kesinlikle kullanılmayacağı, Türkiye Milli DNA Bankası sistemine aktarılmayacağ ve örneklerle birlikte profilin eşleşme olmaması durumunda gecikmeksizin yok edileceği ve silineceği hususunda aydınlatılması ve aydınlatmanın ardından rızasının yazılı olarak alınması gerekir.

Tedbire sadece hâkim/mahkeme karar verebilmelidir. Tedbir kararına başvurmanın son çare olması gerektiği belirtilmelidir. Bu bağlamda failin kimliğini belirlemek bakımından mevcut örneklerin bu kişilere ait olup olmadığının tespiti kesinlikle gerekli olmalı, tedbire tabi tutulacak kişi sayısı ile işlenen fiilin ağırlığı arasında makul bir oran bulunmalıdır. Hâkim/mahkeme kararında bu konuda değerlendirme yaparak, tedbirin gerekçesini açıkça belirtmelidir.

Hükümde suçun aydınlatılması için artık gerekli olmadığı durumlarda elde edilen tüm örneklerin yok edileceği, DNA profillerinin gecikmeksizin silineceği ve bunların belgelendirileceği öngörülmelidir.

\section{Sonuç}

Mevcut çalışmada adlî DNA incelemelerinin tarihî geçmişi, kavramsal ve hukukî olarak anlamı üzerinde kısaca durulmuştur. Koruma tedbiri niteliğinde olan adlî DNA analizlerinin temel hakları ihlal edip etmedikleri tartışmalarına yer verilerek; tedbirin öncelikle vücut bütünlüğü hakkı, kişisel verilerin koruması hakkı (verilerin geleceğini belirleme özerkliği), özel hayatın korunması hakkını ihlal ettiği; ancak mevcut yasal düzenlemelerin anayasal koşullara uymaları sebebiyle anayasa aykırılık oluşmadığ kabul edilmiştir. Buna karşın insan haysiyeti ile hayatın gizli alanına yönelik bir aykırılık saptanmamıştır. Çalışmanın ikinci kısmında TürkCMK ile başta Almanya olmak üzere, Avusturya ve İsviçre ceza muhakemesi hukuku DNA analizlerine ilişkin ortak hükümler karşılaştırmalı olarak ele alınarak gerektiğinde de lege ferenda önerilerde bulunulmuştur. Çalışmanın önemli kısımlarından birini oluşturan son bölümde istatistikî verilere dayanılarak suçların aydınlatılmasında DNA profillerinin 
rolüne vurgu yapılmış, profil verilerinin kaydına ve kitlesel DNA analizlerine yönelik karşılaş̧ırmalı hukuktan faydalanılarak ortaya konulmuş, bu bağlamda Ceza Muhakemesi Kanunu bakımından çeşitli de lege ferenda önerilerde bulunulmuştur. Bunun yanında DNA veri bankalarının kurulması konusunda DNA Verileri ve Türkiye Milli DNA Veri Bankası Kanunu bağlamında bir yasal düzenlemenin acilen hayata geçirilmesi zorunluluğuna değinilmiştir.

\section{Kaynakça}

Aksoy İpekcioğlu, Pervin, Vücuttan Örnek Alma İşleminin Hukukî niteliği ve Anayasaya Uygunluğu, iç: Prof. Dr. Nur Centel'e Armağan, s. 1157 - 1175, (Alıntı: Aksoy İpekcioğlu, iç: Centel'e Armağan, s. )

Altendorfer, Reinhold, „Rechtsprobleme der DNA-Analyse im Strafverfahren“, Münih 2001, (Alıntı: Altendorfer, s. )

Arslan, Kahan Onur, İnsan Onuru Kavramı Ve Koruma Tedbirleri Bağlamında Temel Bir İlke Olarak İnsan Onurunun Korunması, iç: TBBD 2015 (120), s. 155-172, (Alıntı: Arslan, TBBD 2015 (120), s. )

Batur, Necat, Ceza Yargılamasında Moleküler Genetik İnceleme, TBB Dergisi 2016 (126), s. 69 - 94, (Alıntı: Batur, TBBD 2016 (216) s. )

Benecke, Mark, „Kriminalbiologie“, Gladbach 1999, (Alıntı: Benecke, s. ).

Benfer, Jost, „Die molekulargenetische Untersuchung ( $\S 81 \mathrm{e}, 81 \mathrm{~g}$ StPO)“, iç: Strafverteidiger, yıl: 1999, s. 402-404, (Alınt1: Benfer, StV 1999, s. ).

Bergemann, Nils, Hornung, Gerrit, „Die DNA-Analyse nach den Änderungen der StrafprozessordnungSpeicherung bis auf Widerruf?“, iç: Strafverteidiger, Y1l 2007, s. 164-168, (Alıntı: Bergemann/Hornung, StV 2007, s. )

Beulke, Werner, Strafprozessrecht, 10. bask1, Berlin 2008, (Alınt1: Beulke, Strafprozessrecht, s. )

Burr, Kai, „Das DNA-Profil im Strafverfahren unter Berücksichtigung der Rechtsentwicklungen in den USA“, Bonn 1995, (Alıntı: Burr, s.)

Büyükay, Yusuf, Gen Analizleri ve Mukayeseli Hukuktaki Düzenlemeler, AÜEHFD C IX, S. 3-4 (2005), s. 355382, (Alıntı: Büyükay, AÜEHFD C IX, S. 3-4 (2005), s. )

Centel, Nur, Zafer, Hamide, Ceza Muhakemesi Hukuku, 12. Baskı, İstanbul 2015. (Alıntı: Centel/Zafer, CMH, s. )

Çubuk, Mustafa Cem, Kişisel Kimlik Tespit Unsurlarına Ait Veritabanlarının Adlî Araştırmalar Açısından Faydaları ve Türkiye'deki Uygulamaların Değerlendirilmesi (Yüksek Lisans Tezi), (Alıntı: Çubuk, s. )

Deutsche Gesellschaft für Chemisches Apparatewesen, Chemische Technik und Biotechnologie, „Materialien und Basisdaten für gentechnisches Arbeiten und für Errichtung und den Betrieb gentechnischer Anlagen“, Cilt 1 „Biologische Sicherheit“, Frankfurt am Main, 1995, (Alıntı: DECHEMA, s. )

Eisenberg, Ulrich, Beweisrecht der StPO, 9. bask1, Münih 2015, (Alıntı: Eisenberg, Beweisrecht der StPO, s. )

Ellermann, Rolf, Opolka, Uwe, „Genomanalyse: Ihre biochemischen, medizinischen, juristischen und politischen Aspekte“, Frankfurt am Main, 1991, (Alınt1: Ellermann/Opolka, s. )

Elmas, İmdat, Ersoy, Gökhan, Adlî Olgulardan Biyolojik Örnek Alınması ve Moleküler Genetik İncelemelerde Yasal Boyut, Klinik Gelişim, s. 111-113, (Alıntı: Elmas/Ersoy, iç: Klinik Gelişim, s. )

Finger, von Thorsten, „Einwilligung in die Entnahme und Untersuchung von Körperzellen“, iç: Kriminalistik, Jahrgang 2006, s. 696-700, (Alint1: Finger, s. )

Foldenauer, Wolfgang, „Genanalyse im Strafverfahren“, Berlin 1995 (Alıntı: Foldenauer, s. )

Gola, Peter, Schomerus, Rudolf, Klug, Christoph, „Bundesdatenschutzgesetz: Kommentar“, 8. Baskı, Münih 2005, (Alıntı: Gola/Schomerus/Klug, BDSG, § ... pn. ...) 
Harbort, Stephan, „Der Beweiswert der Blutprobe“, Stuttgart 1994, (Alıntı: Harbort, s. )

Henke, Jürgen, Scmitter, Hermann, „DNA- Polymorphismen in forensischen Fragestellungen“, iç: Monatsschrift für deutsches Recht, Jahrgang 1989, s. 404-406, (Alıntı: Henke/Schmitter, MDR 1989, s. )

Hetger, Erwin, „Chancen und Risiken neuer Techniken“, iç: Die Polizei, Y11 2003, s. 333-337, (Alıntı: Hetger, s. )

Joecks, Wolfgang, „Studienkommentar zur Strafprozessordnung“, 1. Baskı, 2006, Münih, (Alıntı: Joecks, StK$\mathrm{StPO}, \S \ldots$......)

Keller, Rainer, „Die Genomanalyse im Strafverfahren“, iç: Neue Juristische Wochenschrift, Yı1 1989, s. 22892296, (Alıntı: Keller, NJW 1989, s. )

Kindhäuser, Urs, Strafprozessrecht, 7. bask1, Baden Baden, 2015, (Alıntı: Kindhäuser, Strafprozessrecht, s. )

Klumpe, Birgit, „Der genetische Fingerabdruck im Strafverfahren: Rechtsprobleme bei der Anwendung genetischer Analysen in Großbritannien und Deutschland“, Freiburg 1993, (Alınt1: Klumpe, s. )

Knauer, Christoph, Kudlich, Hans, Schneider, Hartmut, Münchener Kommentar zur StPO, 1. Cilt, 1. bask1, Münih 2014, (Alıntı: Münchener Kommentar-Trück, StPO, m. 80e sn. )

Krehl, Christoph, Kolz, Alexander, „Genetischer Fingerabdruck und Verfassung““, iç: Strafverteidiger, Y1l 2004 , s. 447-455, (Alıntı: Krehl/Kolz, StV 2004, s. )

Krieglstein, Marco, ,Der genetische Fingerabdruck zur Personenidentifizierung im Strafverfahren: Zur Frage des gesetzgeberischen Handlungsbedarfs“, Holzkirchen 1994, (Alıntı: Krieglstein, s. )

Mahmutoğlu, Fatih Selami, Moleküler Genetik İncelemenin Ceza Yargılaması Hukuku Bağlamında Analizi, son erişim: 15.01.2017, (Alıntı: Mahmutoğlu, s. 4, iç: http://fsmahmutoglu.av.tr/ pdf/27b485a20728432f3c6b2f169f7a8f80c62998517818071225.pdf, son erişim: )

Meyer-Goßner, Lutz, „Beck’ische Kurz Kommentare zur Strafprozessordnung mit Gerichtsverfassungsgesetzt, Nebengesetzen und ergänzende Bestimmungen“, 59. Bask1, Münih 2016. (Alıntı: Meyer-Goßner/Schmitt, StPO, $\S 81$ e s. )

Nagl, Walter, „Gentechnologie und Grenzen der Biologie“, Darmstadt 1987, (Alıntı: Nagl, s. )

Neuser, Markus, „Rechtsfragen der DNA-Analyse zum Zweck der DNA-Identitätsfeststellung in künftigen Strafverfahren“, 1. Bask1, Baden-Baden 2006, (Alıntı: Neuser, s. )

Özbek, Veli Özer, Ceza Muhakemesi Hukukunda DNA-Analizi, iç: http://www.hukukî.net/www.saglikhukuku. net/bilgi/a044.asp, son erişim: 6.1.2017, (Alıntı: Özbek, son erişim: )

Özbek, Veli Özer, DNA Verileri ve Türkiye Milli DNA Veri Bankası Kanunu Tasarısı Hakkındaki Görüşlerimiz, iç: Ceza Hukuku Dergisi, Nisan 2007, Sayı: 1, s. 47 - 76, (Alıntı: Özbek, CHD, Nisan 2007, Sayı: 1, s. )

Özbek, Veli Özer, Kanbur, Nihat, Doğan, Koray, Bacaksız, Pınar, Tepe, İlker, 7. Baskı, Ankara 2015, (Alıntı: Özbek/Diğerleri, CMH, s. )

Öztürk, Bahri, Tezcan, Durmuş, Erdem, Mustafa Ruhan, Sırma, Özge, Kırıt, Yasemin F. Saygılar, Özaydın, Özdem, Akcan, Esra Alan, Erden, Efser, Nazari ve Uygulamalı Ceza Muhakemesi Hukuku, 9. Baskı, Ankara 2015, (Alıntı: Öztürk/Diğerleri, CMH, s. )

Öztürk, Gülsüm Ezgi, Adlî DNA ve Kimliklendirme (Bitirme Tezi) (2015), (Alıntı: Öztürk, s. )

Pieroth, Bodo, Jarass, Hans, „Grundgesetz-Kommentar“, 8. Bask1, Münih 2006, (Alıntı: Pieroth/Jarass, Grundgesetz, $\S \ldots$ pn. ...)

Rackow, Peter, „Das DNA-Identitätsfeststellungsgesetz und seine Probleme“, Frankfurt am Main 2001, (Alıntı: Rackow, s. )

Rademacher, Christine , „Zur Frage der Zulässigkeit genetischer Untersuchungsmethoden im Strafverfahren“, iç: Strafverteidiger, Y11 1989, s. 546- 551, (Alıntı: Rademacher, StV 1989, s. )

Roxin, Claus, Schünemann, Bernd, Strafverfahrensrecht, 27. Bask1, Münih, 2012, (Alıntı: Roxin/Schünemann, Strafverfahrensrecht, s. ) 
Schewe, Christoph, „Qua vadis genetischer Fingerabdruck? Zum Regelungsbedarf bei der Speicherung von DNA-Identifizierungsmuster“, iç: Juristischer Rundschau, Y1l 2006, s. 181-188, (Alıntı: Schewe, JR 2006, s. )

Senge, Lothar, „Die Neuregelung der forensischen DNA-Analyse“, iç: Neue Juristische Wochenschrift, Jahrgang 2005, s. 3028-3033, (Alınt1: Senge, NJW 2005, s. )

Senge, Lothar, „Gesetzt zur Änderung der Strafprozessordnung (DNA-Identitätsfeststellungsgesetz)“, iç: Neue Juristische Wochenschrift, Y11 1999, s. 253-256, (Alıntı: Senge, NJW 1999, s. )

Senge, Lothar, Strafverfahrensänderungsgesetz - DNA-Analyse, iç: Neue Juristische Wochenschrift, Y1l 1997, s. 2409-2412, (Alınt1: Senge, NJW 1997, s. 2410.)

Simitis, Spiros, „Kommentar zum Bundesdatenschutzgesetz“, 5. Baskı, Baden-Baden 2003, (Alıntı: Simitis, BDSG/Bearbeiter, $\S \ldots$......)

Sternberg-Lieben, Detlev, „,,Genetischer Fingerabdruck“ und § 81a StPO“, iç: Neue Juristische Wochenschrift, Y1l 1987, s. 1242-1247, (Alıntı: Sternberg-Lieben, NJW 1987, s. )

Stumper, Kai, „Informationelle Selbstbestimmung und DNA-Analysen: zur Zulässigkeit der DNA-Analyse am Menschen angesichts des Informationellen Selbstbestimmungsrechts aus Art, 2 I i. V. m. Art. 1 I GG“, Frankfurt am Main 1996, (Alıntı: Stumper, s. )

Şahin, Cumhur, Ceza Muhakemesi Hukuku I, Cilt 1, 6. Baskı, Ankara 2015, (Alıntı: Şahin, CMH I, s. )

Şahin, Cumhur, Göktürk, Neslihan, Ceza Muhakemesi Hukuku II, Cilt 2, 5. Baskı, Ankara 2016, (Alıntı: Şahin/ Göktürk, CMH II, s. )

Ünver, Yener, Ceza Hukuku Felsefesi Açısından İnsan Onuru ve Mevzuatımız, Ceza Hukuku Dergisi, Yıl: 3, Say1 7, 2008, s. 41-82, (Alıntı: Ünver, CHD, Y11: 3, Sayı 7, 2008, s. )

Ünver, Yener, Hakeri, Hakan, Ceza Muhakemesi Hukuku, Cilt 1, 11. Baskı, Ankara 2016, (Alıntı: Ünver/ Hakeri, CMH, s. )

Volk, Elisabeth, ,DNA-Identitätsfeststellungsgesetz- Kein Ende der Begehrlichkeiten“, iç: Neue Zeitschrift für Strafrecht, Jahrgang 2002, s. 561-565, (Alınt1: Volk, NStZ 2002, s. )

Volk, Klaus, Engländer, Armin, Grundkurs StPO, 8. Baskı, Münih, 2013, (Alıntı: Volk/Engländer, Grundkurs StPO, s. )

Von Münch, Ingo, Kunig, Philip, „Grundgesetz-Kommentar“, Cilt I, 5. Baskı, Münih 2000, (Alıntı: Münch/ Kunig-Kunig, GGK I, m. ... pn ...)

Weichert, Thilo, „Informationelle Selbstbestimmung und strafrechtliche Ermittlung: zum verfassungskonformen Technikeinsatz im Strafverfahren“, Freiburg 1990, (Alıntı: Weichert, s. )

Wolter, Jürgen, Systematischer Kommentar zur Strafprozessordnung, Cilt 1, 4. Baskı, Köln 2014, (Alıntı: SKStPO, Cilt I, s. )

Yenisey, Feridun, Nuhoğlu, Ayşe, Ceza Muhakemesi Hukuku, 3. Baskı, Ankara 2015, (Alıntı: Yenisey/Nuhoğlu, CMH, s. )

Zafer, Hamide, Özel Hayatın ve Hayatın Gizli Alanının Ceza Hukukuyla Korunması (TCK m. 132-134), 1. Baskı, 2010 İstanbul, (Alıntı: Zafer, s. ) 
